UNITED STATES

DEPARTMENT OF THE INTERIOR

GEOLOGICAL SURVEY

\title{
ASSESSMENT OF REGIONAL EARTHQUAKE HAZARDS AND RISK ALONG THE WASATCH FRONT, UTAH
}

\section{VOLUME III}

\author{
Editors
}

Paula L. Gori

Walter W. Hays

U.S. Geological Survey

Reston, Virginia 22092

Compiled by

Carla Kitzmiller

Open-File Report 88-680

This report is preliminary and has not been reviewed for conformity with U.S. Geological Survey editorial standards and stratigraphic nomenclature. The views and conclusions contained in this document are those of the authors and should not be interpreted as necessarily representing the official policies, either expressed or implied, of the United States Government. Any use of trade names and trademarks in this publication is for descriptive purposes only and does not constitute endorsement by the U.S. Geological Survey. 


\section{Knowledge Utilization Series \\ Reports To Date}

Open File 84-770 Proceedings of the Symposium on the New Madrid Seismic Zone

Open File 84-772 Primer on Improving the State of Earthquake Hazards Mitigation and Preparedness

Open File 86-185 A Workshop on "Probabilistic Earthquake Hazards Assessments"

Open File 86-401 A Workshop on "Future Directions in Evaluating Earthquake Hazards of Southern California"

Open File 87-008 A Workshop on "Assessment of Geologic Hazards and Risk in Puerto Rico"

Open File 87-269 A Workshop on "The U.S. Geological Survey's Role in Hazards Warnings"

Open File 87-585 Assessment of Regional Earthquake Hazards and Risk Along the Wasatch Front, Utah

Open File 88-13-A A workshop on "A Review of Earthquake Research

Applications in the National Earthquake Hazards Reduction Program: 1977-1987"

For Ordering Information Contact:

U.S. Geological Survey

Books and Open-file Reports

Federal Center, Building 810

Box 25425

Denver, Colorado 80225 
FOREWORD

This report represents an ongoing U.S. Geological Survey effort to transfer accurate earth science information about earthquake hazards along the Wasatch front, Utah to researchers, public officials, design professionals, land-use planners, and emergency managers in an effort to mitigate the effects of earthquake hazards. This report is a preview of the future U.S. Geological Survey professional paper on regional earthquake hazards and risk along the Wasatch front.

Currently State and local governments, private institutions, and individuals are implementing earthquake hazards reduction measures in Utah. The success of their efforts will depend, in part, on the availability of accurate earth science information. The timeliness and importance of the multidisciplinary research contained in this report and the need for its utilization has made it imperative to release the information in the form of an open-file report while the process of publishing the professional paper is being completed.

The report is organized into 3 volumes. Volume I contains chapters on the tectonic framework and earthquake potential of the Wasatch front area. Volume II contains chapters on the ground shaking hazards and aspects of loss estimation, as well as, chapters on the use of hazards information for urban and regional planning and development. Volume III contains chapters on loss estimation which were unavailable at the time Volume II (Open-File 87-585) was published. Many of the chapters are in draft format and, therefore, the figures follow the text.

The information contained in this report is the latest and most accurate information available on earthquake hazards along the Wasatch front and may be used and cited until such time as the Professional Paper on "Regional earthquake hazards and risk along the Wasatch front," is published.

Paula L. Gori

Walter W. Hays

Editors 


\section{ASSESSMENT OF REGIONAL EARTHQUAKE \\ HAZARDS AND RISK ALONG THE WASATCH FRONT, UTAH}

Table of Contents

VOLUME I

INTRODUCTION TO ASSESSMENT OF REGIONAL EARTHQUAKE HAZARDS AND RISK ALONG

THE WASATCH FRONT, UTAH

by Paula L. Gori and Walter $W$. Hays.......................... 1-12

THE TECTONIC FRAMEWORK AND EARTHQUAKE POTENTIAL OF THE WASATCH FRONT AREA

Quaternary Geology Along the Wasatch Fault Zone: Segmentation, Recent

Investigations, and Preliminary Conclusions

by Michael N. Machette, Stephen F. Personius, and Alan R. Nelson.... A-1-72

Persistent and Nonpersistent Segmentation of the Wasatch Fault Zone,

Utah -- Statistical Analysis for Evaluation of Seismic Hazard

by Russell L. Wheeler and Katherine B. Krystinik................B-1-124

Subsurface Geology Along the Wasatch Front

by Don R. Mabey.................................... C-1-39

Observational Seismology and the Evaluation of Earthquake Hazards

and Risk in the Wasatch Front Area, Utah

by Walter J. Arabasz, James C. Pechmann, and Ethan D. Brown......... D-1-39

Superimposed Late Cenozoic, Mesozoic, and Possible Proterozoic

Deformation Along the Wasatch Fault Zone in Central Utah

by Mary Lou Zoback........................................ E-1-43

Neotectonic Framework of the Central Sevier Valley Area, Utah, and

Its Relationship to Seismicity

by R. Ernest Anderson and Theodore P. Barnhard................... $-1-134$

Neotectonics of the Hansel Valley-Pocatello Valley Corridor, Northern Utah, and Southern Idaho

by James McCalpin, Robert M. Robison, and John D. Garr.............G-1-44

Structure of the Salt Lake Segment, Wasatch Normal Fault Zone:

Implications for Rupture Propagation During Large Earthquakes

by R. L. Bruhn, P. R. Gibler, W. Houghton, and W. T. Parry.........H-1-57

Quaternary Displacement on the Morgan Fault, a Back Valley Fault

in the Wasatch Range of Northeastern Utah

by J. Timothy Sullivan \& Alan R. Nelson..................... I-1-53

Late Quaternary History of the James-Peak Fault Southernmost

Cashe Valley North-Central Utah

by Alan R. Nelson and J. Timothy Sullivan.....................J-1-39 
VOLUME II

THE GROUND-SHAKING HAZARDS AND ASPECTS OF LOSS ESTIMATION IN THE

WASATCH FRONT AREA

Site Amplification in the Salt Lake City-Ogden-Provo, Utah,

Corridor and the Implications for Earthquake-Resistant Design

by Walter Hays.................................................

Predicting Strong Ground Motion in Utah

by Kenneth W. Campbe11................................ L-1-90

Probabilistic Analysis of Earthquake Ground Shaking Hazard Along

the Wasatch Front, Utah

by R. R. Youngs, F. H. Swan, M. S. Power, D. P. Schwartz, and

R. K. Green...........................................1-110

Relative Ground Response in Salt Lake City and Areas of Springville-

Spanish Fork, Utah

by Kenneth $W$. King, Robert A. Williams, and David L. Carver......... N-1-48

In Situ Poisson's Ratio Measurements Near Provo, Utah

by Richard D. Miller, Don W. Steeples, Kenneth W. King, and

Ralph W. Knapp........................................ 0-1-26

Effects of Six Damaging Earthquakes in Salt Lake City, Utah

by Sherry D. Oaks...................................... P-1-95

Earthquake Hazards to Domestic Water Distribution Systems in

Salt Lake County, Utah

by Lynn M. Highland.

$Q-1-76$

THE USE OF EARTHQUAKE HAZARDS INFORMATION FOR URDAN AND REGIONAL PLANNING AND

DEVELOPMENT IN THE WASATCH FRONT AREA

Making the Implementation Process of the National Earthquake

Hazards Reduction Program Work in Utah

by Walter . Hays...................................... R-1-44

Reducing Earthquake Risk in Utah: Past Trends and Future Opportunities

by Genevieve Atwood and Don R. Mabey........................ S-1-38

Emergency Management in Utah for Earthquakes

by James L. Tingey and Ralph F. Findlay.................... T-1-19

Utah Geological and Mineral Survey Excavation and Inspection Program:

A Tool for Earthquake Hazard Recognition in Utah

by Harold E. Gil1........................................ U-1-19

Rock Fall Hazard Susceptibility Due to Earthquakes, Central

Wasatch Front, Utah

by William F. Case.................................. V-1-36

Legal Issues Related to Hazard Mitigation Policies

by James E. Slosson.................................. W-1-7 


\section{VOLUME III}

Earthquake Losses in Central Utah

by S T. Algermissen, E. P. Arnold, K. V. Steinbrugge, M. G. Hopper,

and P. S. Powers...................................... X-1-62

Isoseismals of Some Historical Earthquakes Affecting the Wasatch Front Area, Utah

by Margaret G. Hopper................................ Y $-1-28$

Seismic Risk Methods and Estimates for Utility Systems and State-Owned Buildings Along the Wasatch Front

Craig E. Taylor, Delbert B. Ward, and Jerold M. Harber.............. Z-1-62 


\section{EARTHQUAKE LOSSES IN CENTRAL UTAH}

\section{by \\ S. T. Algermissen ${ }^{1}$, E. P. Arnold ${ }^{1}$, K. V. Sţeinbrugge ${ }^{2}$, \\ M. G. Hopper ${ }^{1}$, and P. S. Powers}

ABSTRACT

Estimates of losses for Central Utah have been made for a series of simulated earthqukes treated both as deterministic (scenario) and probabiistic. Losses from scenario earthquakes of $M_{S}=7.5$ and $=6.5$ and $M_{L}=5.5$ on each of the Provo, Salt Lake, and Weber segments of the Wasatch fault were considered as well as an $M_{S}=7.5$ earthquake on a hypothetical fault about $30 \mathrm{~km}$ west of Salt Lake City. Expected maximum losses in the Salt Lake City urban corridor in 50 years with a ten percent chance of exceedance were also found. Inventory of building stock was obtained for all classes of construction. The lusses range from $\$ 830$ million for a $M_{L}=5.5$ shock on the Provo segment to $\$ 5.5$ billion for a $M_{S}=7.5$ quake on the salt Lake segment. The sensitivity of these loss estimates to changes in intensity, vulnerability relationships, and substrate materials are discussed.

\section{INTRODUCTION}

Only limited attention has been given in the technical literature to the potential for earthquake losses in central Utah. The most important previous study is that of Rogers and others (1976), which dealt primarily with the severity of damage to facilities critical to earthquake preparedness planning, such as hospitals and related medical services, dams, state buildings, transportation, public utilities, food supplies and debris removal.

Casuaities were also estimated. No estimates of monetary loss were given. In their study, the effects of $M_{S}=7.5$ earthquakes located both on the Wasatch fault and approximately $10 \mathrm{~km}$ west of the fault in the vicinity of salt Lake City, Odgen and Provo were simulated.

\section{U.S. Geological Survey, Denver, Colorado


Algermissen and Steinbrugge (1984) provided aggregate estimates of monetary losses for Salt Lake City for two probabilistic ground motion models and one deterministic, scenario type $\left(M_{S}=7.5\right)$ earthquake located on the Wasatch fault in Salt Lake City. Site response, based on the work of Hays and others (1978) was included in the deterministic models.

Improvements in our understanding of the seismotectonics of the Wasatch fault, recent studies of site response and an improved and expanded inventory of buildings in Utah, Salt Lake, Weber and Davis Counties (Steinbrugge, 1986) provided incentive for undertaking the present work.

\section{PURPOSE AND SCOPE OF THIS STUDY}

The purpose of this study is to estimate primary monetary losses associated with an ensemble of earthquakes to a range of buildings in Utah, Salt Lake, Davis and Weber Counties (Figure 1). These four counties contain 77 percent of the population of Utah and over 90 percent of the buildings exceeding $\$ 1.0$ million in original cost. The five classes of buildings (referred to as Classes $I-V$ ) considered in the study are described in Table 1. These classes encompass the majority of buildings in the four county area, with the exception of schools, government buildings and heavy industrial complexes. Estimated earthquake losses to the water supply system and to certain selected types of structures are contained in other papers in this volume.

Both deterministic (scenario) and probabilistic loss studies were undertaken. Losses were estimated for scenario earthquakes on the Provo, Salt Lake City (or Salt Lake) and Weber segments (Machette and others, 1987) of the Wasatch fault. Earthquakes of niagnitude $\left(M_{S}\right)$ of $7.5,6.5$ and $\left(M_{L}\right) 5.5$ were simulated on each fault segment. Additionally, an earthquake of magnitude $M_{S}=7.5$ was simulated on a hynthetical fault on the west side of the Oquirrh 


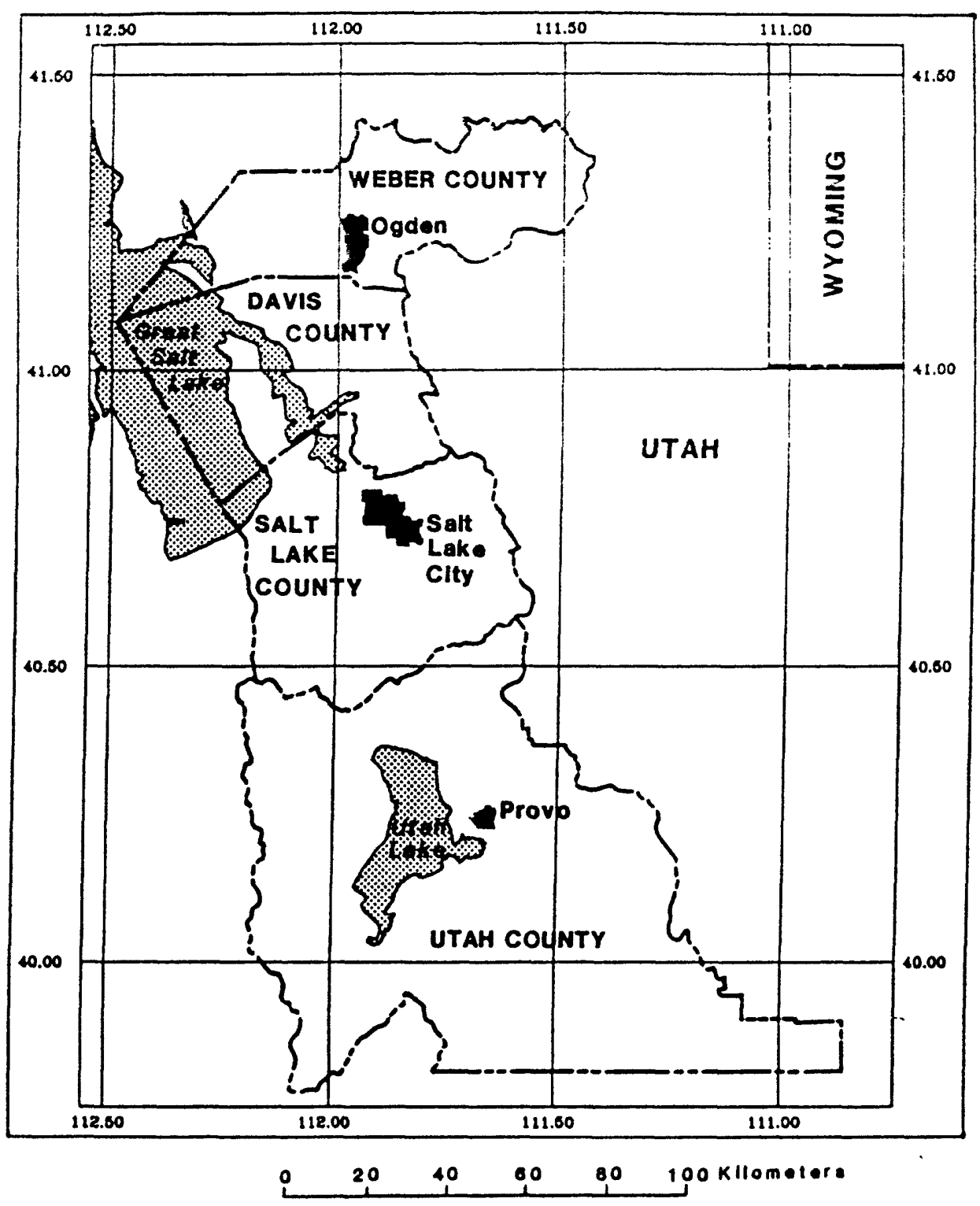

FIGURE 1. Location map of the four county area. 
TABLE 1.--Building classification used in this study

Class I-Wood Frame

Class I-A

1. Wood frame and frame stucso dwellings regardless of area and height.

2. Wood frame and frame stucco buildings, other than dwellings, which do not exceed 3 stories in height and do not exceed $3,000 \mathrm{sq} f t$ in ground floor area.

3. Wood frame and frame stucco habitational structures which do not exceed 3 stories in height regardless of area.

Class I-B

Wood frame and frame stucco buildings not qualifying under Class I-A.

Class II-All-metal buildings

Class II-A

One story all-metal buildings which have a floor area not exceeding 20,000 sq ft.

Class II-B

All-metal buildings not qualifying under Class II-A.

Class III-Steel frame buildings

Class III-A

Buildings having a complete steel frame with all loads carried by the steel frame. Floors and roofs shall be of poured-in-place reinforced concrete, or of concrete fill on metal decking welded to the steel frame (open web steel joists excluded). Exterior walls shall be of poured-in-place reinforced concrete or of reinforced unit masonry placed within the frame. Buildings shall have a least width to height above ground (or above any setback) ratio of not exceeding one to four. Not qualifying are buildings having colurin-free areas greater than $2,500 \mathrm{sq} f t$ (such as auditoriums, theaters, pu'jlic halls, etc.) 
Class III-Steel frame buildings

\section{Class III-B}

Buildings having a complete steel frame with all loads carried by the steel frame. Floors and roofs shall be of poured-in-place reinforced concrete or metal, or any combination thereof, except that roofs on buildings over three stories may be of any material. Exterior and interior walls may be of nonload carrying material.

Class III-C

Buildings having some of the favorable characteristics of Class III-A but otherwise falling into Class III-B.

Class III-D

Buildings having a complete steel frame with floors and roofs of any material and with walls of any non-load bearing materials.

\section{Class IV-Reinforced concrete, combined reinforced concrete and structural steel frame}

Note: Class IV-A, $B$, and $C$ buildings shall have all vertical loads carried by a structural system consisting of one or a combination of the following: (a) poured-in-place reinforced concrete frame, (b) pouredin-place reinforced concrete bearing walls, (c) partial structural steel frame with (a) and/or (b). Floors and roof shall be of pouredin-place reinforced concrete, except that materials other than reinforced concrete may be used for the roofs on buildings over 3 stories.

Class IV-A

Buildings having a structural system as defined by the note (above) with poured-in-place reinforced concrete exterior walls or reinforced unit masonry exterior walls placed within the frame. Buildings shall have at least width to height above ground (or above any setback) ratio of not exceeding one to three. Not qualifying are buildings having column-free areas greater than $2,500 \mathrm{sq}$ I't $^{\prime}$ (such as auditoriums, theaters, public halls, and so forth).

Class IV-B

Buildings having a structural system as defined by the note (above) with exterior and interior nonbearing walls of any material. 
Class $\mathrm{V}-\mathrm{A}$

1. Dwellings, not over two stories in height, constructed of poured-in-place reinforced concrete, with roofs and second floors of wood frame.

2. Dwellings, not over two stories in height, constructed of adequately reinforced brick or hollow concrete block masonry, with roofs and floors of wood.

Class $\mathrm{V}-\mathrm{B}$

One story buildings having superior earthquake damage control features including exterior walls of (a) poured-in-place reinforced concrete, and/or (b) precast reinforced concrete, and/or (d) reinforced hollow concrete block masonry. Roofs and supported floors shall be of wood or metal diaphragm assemblies. Interior bearing walls shall be of wood frame or any one or a combination of the aforementioned wall materials.

Class V-C

One story buildings having construction materials listed for Class $\mathrm{V}-\mathrm{B}$, but with ordinary earthquake damage control features.

\section{Class V-D}

1. Buildings having reinforced concrete load bearing walls with floors and roofs of wood and not qualifying for Class IV-E.

2. Buildings of any height having Class $V-B$ materials of construction, including wall reinforcement; also included are buildings with roofs and supported floors of reinforced concrete (precast or otherwise) not qualifying for Class IV.

Class V-E

Buildings having unreinforced solid unit masonry of unreinforced brick, unreinforced concrete brick, unreinforced stone, or unreinforced concrete, where the loads are carried in whole or in part by the walls and partitions. Interior partitions may be wood frame or any of the aforementioned materials. Roofs and floors may be of any material. Not qualifying are buildings with nonreinforced load carrying walls of hollow tile or other hollow unit masonry, adobe, or cavity construction.

Class $\mathrm{V}-\mathrm{F}$

1. Buildings having load carrying walls of hollow tile or other hollow unit masonry construction, adobe, and cavity wall construction.

2. Any building not covered by any other class. 
Classes VI-A, B, C, D, and E-Earthquake resistive construction

Any building or structure with any combination of materials ard with earthquake damage control features equivalent to those found in Classes I through $V$ buildings. Alternatively, a qualifying building or structure may be classed as any class from I through $V$ (instead of VI-A, B, C, D, or E) if the construction resembles that described for one of these classes and if the qualifying building or structure has an equivalent damageability. 
Mountains, approximately $30 \mathrm{~km}$ west of Salt Lake City. The expected maximum losses in 50 years with a 10 percent chance of exceedance were also calculated using a slightly modified version of the probabilistic model described by Algermissen and others (1982).

ASSESSMENT OF LOSSES

\section{Introduction}

A general flow diagram for earthquake ground shaking loss ( $r$ isk) studies is shown in Figure 2. The following sections describe each of the parameters in the loss estimation procedure shown in Figure 2 (Hazard Assessment, Inventory and Vulnerability) as it applies to this study. Ground Shaking Hazard Assessment

Both deterministic and probabilistic ground motion hazard models were developed for the estimation of earthquake losses. Deterministic (scenario) ground shaking models were developed for hypothesized earthquakes of magnitude $\left(M_{S}\right) 7.5,6.5$ and $\left(M_{L}\right) 5.5$ located on the Provo, Salt Lake and Weber segments of the Wasatch fault (Machette and others, 1987) and an $M_{S}=7.5$ shock west of Salt lake City. All of the earthquakes were assumed to have surface ruptures. The ruptures begin at the center of each fault segment and rupture bilaterally over a distance $\log \mathrm{L}=1.915+0.389 \mathrm{M}$ (Mark, 1977) where $\mathrm{L}$ is the fault rupture length in meters and $M$ is taken to be $M_{L}$ for magnitudes less than 6.5 and $M_{S}$ for earthquakes 6.5 and larger. The earthquakes are not allowed to rupture out of the fault segment in which they occur. Since some of the Wasatch fault segmerits are much shorter than the fault rupture length given by Mark's (1977) regression equation, the length of the fault rupture for the larger simulated earthquakes is generally controlled by the lengtii of the Wasatch fault segment. The assumed magnitudes and rupture lengths are summarized in Table 2. 


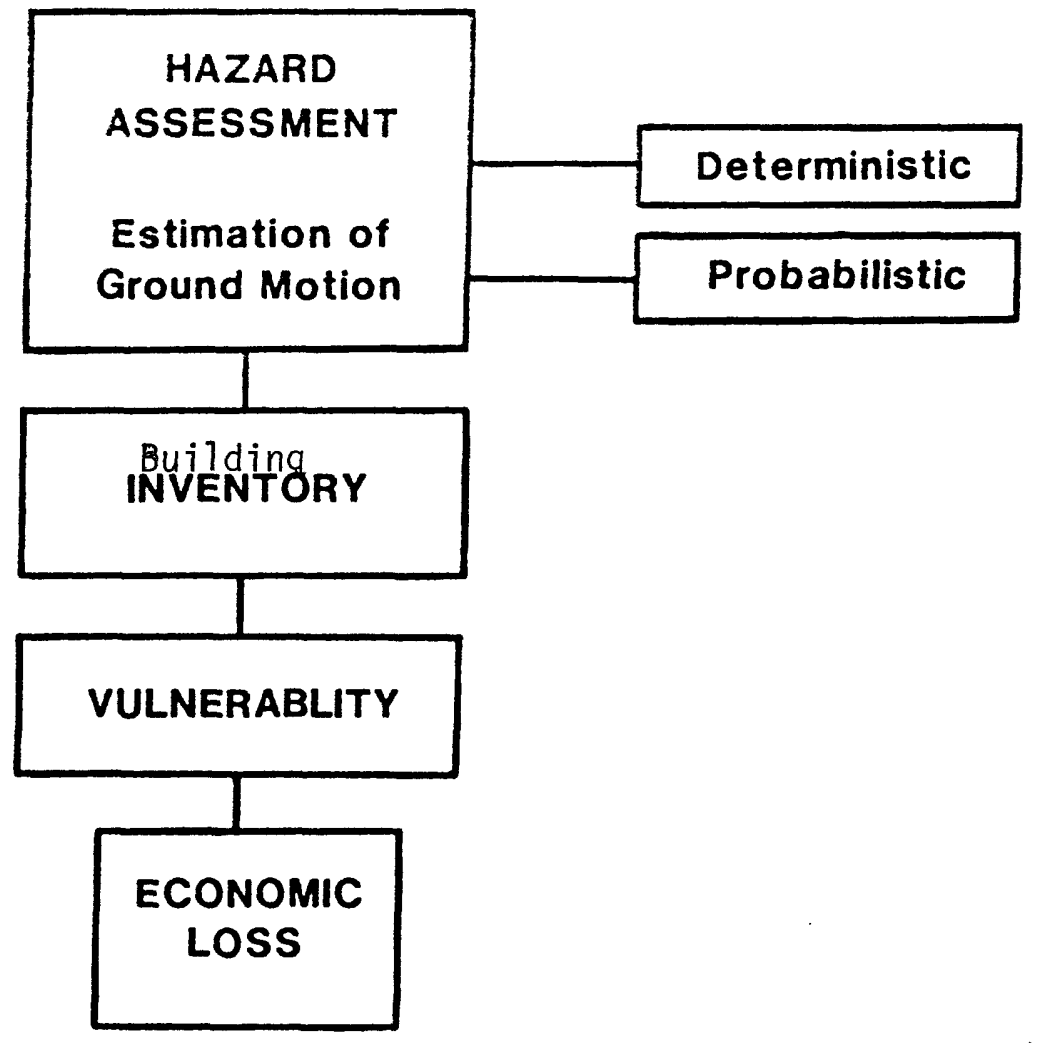

FIGURE 2. General flow diagram of risk assessinent procedure and its parameters. 
TABLE 2. Scenario Earthquake Parameters

\begin{tabular}{|c|c|c|c|c|c|}
\hline \multirow[b]{2}{*}{ Magnitude } & \multirow[b]{2}{*}{$\frac{I}{(\operatorname{maximum})}$} & \multicolumn{4}{|c|}{ Length of Faulting $(\mathrm{km})$} \\
\hline & & $\begin{array}{l}\text { Provo } \\
\text { Segment }\end{array}$ & $\begin{array}{l}\text { Salt Lake } \\
\text { Segment }\end{array}$ & $\begin{array}{l}\text { Weber } \\
\text { Segment }\end{array}$ & $\begin{array}{l}\text { Oquirrh Mountains } \\
\text { (hypothetical fault, west } \\
\text { side of Oquirrh Mountains, } \\
\text { see Figs. } 1 \text { and } 2 \\
\end{array}$ \\
\hline $7.5 \mathrm{M}_{\mathrm{S}}$ & $x+(10.3)$ & 18 & 30 & 50 & 30 \\
\hline $6.5 \mathrm{M}_{\mathrm{S}}$ & $1 \times(9.0)$ & 18 & 28 & 28 & \\
\hline $5.5 \mathrm{M}_{\mathrm{L}}$ & $\operatorname{VIII}(8.0)$ & 11 & 11 & 11 & \\
\hline
\end{tabular}

The number in the parenthesis is the actual maximum intensity $\left(I_{0}\right)$ used in the calculation of intensity in equation 1 , thus

$$
\left(I_{0}-I\right)=10 \exp \{-4.21873+0.604413 \ln (x)\}+K
$$

where $I$ is the intensity at distance $x$ from the surface trace of the fault rupture and $K$ is a correction for surficial material (see Table 3 ). 
The rationale for the selection of a magnitude $\left(M_{S}=7.5\right)$ shock as the largest earthquake to be simulated on the Wasatch fault (and west of Salt Lake City) is that: (1) earthquakes of this magnitude have occurred historically in the Basin and Range Province (in the Nevada Seismic Zone); and (2) paleoseismic evidence supports the idea that earthquakes of this magnitude are possible on segments of the Wasatch fault (Machette and others, 1988). The maximum MM intensities assigned to the earthquakes to be simulated are based on: (1) consideration of maximum intensities observed in recent earthquakes with surface faulting; and, (2) the high amplification ratios (amplitudes on alluvium to amplitudes on rock) observed in the Salt Lake Urban Corridor. All of the $I_{\max }$ values in Table 2 represent an estimate of the most intense shaking that might occur on surficial materials with the greatest site response. For this study this material is taken to be silt and clay (as classified by Rogers and others, 1984). An $I_{\max }$ of intensity $X+$ is considered appropriately conservative for the maximum shaking on silt and clay for a $M_{S}=7.5$ earthquake. A maximum intensity of $I X$ is considered a reasonable shoice for the maximum shaking silt and clay for a $M_{S}=6.5$ earthquake. Maximum intensities of IX were widely observed in the $M_{S}=6.2$ Managua, Nicaragua earthquake of 1972 (Algermissen and others, 1974; Dewey and others, 1974) and the $M_{S}=6.5$ San Fernando, California earthquake of 1971 (Murphy, 1973). Both of these earthquakes had surface faulting. A maximum intensity of VIII was used for the maximum shaking for the $M_{L}=5.5$ earthquakes simulated. Intensity VIII was widely observed arter the $1986, M_{S}=5.4$ earthquake that occurred at very shallow depth beneath the city of San Salvador (Ríos and others, 1986). The above examples suggest that reasonable choices for maximum MM intensity have been made for the earthquakes simulated in the Utah Urban Corridor. 
The ground shaking attenuation in terms of Modified Mercalli (MM) intensity was calculated for the simulated earthquakes by combining an attenuation curve derived from 475 intensity observations in Utah reported by Hopper (this volume) with site response data generalized by Rogers and others (1984). The equation used is

$$
\left(I_{O}-I\right)=10 \exp \{-4.21873+0.604413 \ln (x)\}+K
$$

where $I_{0}$ is the maximum MM intensity for each earthquake (see Table 2) and I is MM intensity at $x$, the closest distance from the surface trace of the fault to the center of housing of each Census Tract in the four county area. The standard deviation of one intensity observation, $\sigma_{I}$, is 1.038 . K is a correction factor for site response (Table 3 ).

The $K$ term in equation (1) modifies the intensity attenuation making use of the site response data of Rogers and others (1984). They used recordings by King and others (1983) of small earthquakes and blasts at 42 locations in the Wasatch Front Urban Corridor to derive log normal mean of the mean spectral ratios in two period bands for three lithologic categories (silt and clay, sand and gravel and rubble) with respect to rock. The two period bands over which the spectral ratios were averaged are $0.2-0.7 \mathrm{~s}$ and $0.7-1.0 \mathrm{~s}$. Only the log normal means for the short period band $(0.2-0.7 \mathrm{~s})$ are used here for two reasons. First, most of the structures of interest in this loss study are best represented by short-period band amplification, that is, the fundamental periods of vibration of the majority of buildings in the four county area are best represented by the site response data in the $0.2-0.7 \mathrm{~s}$ period band, and second, Rogers and others (1984) did not find the amplification data in the longer period band (0.7-1.05) statistically significant. 
TABLE 3. Site Response Factors

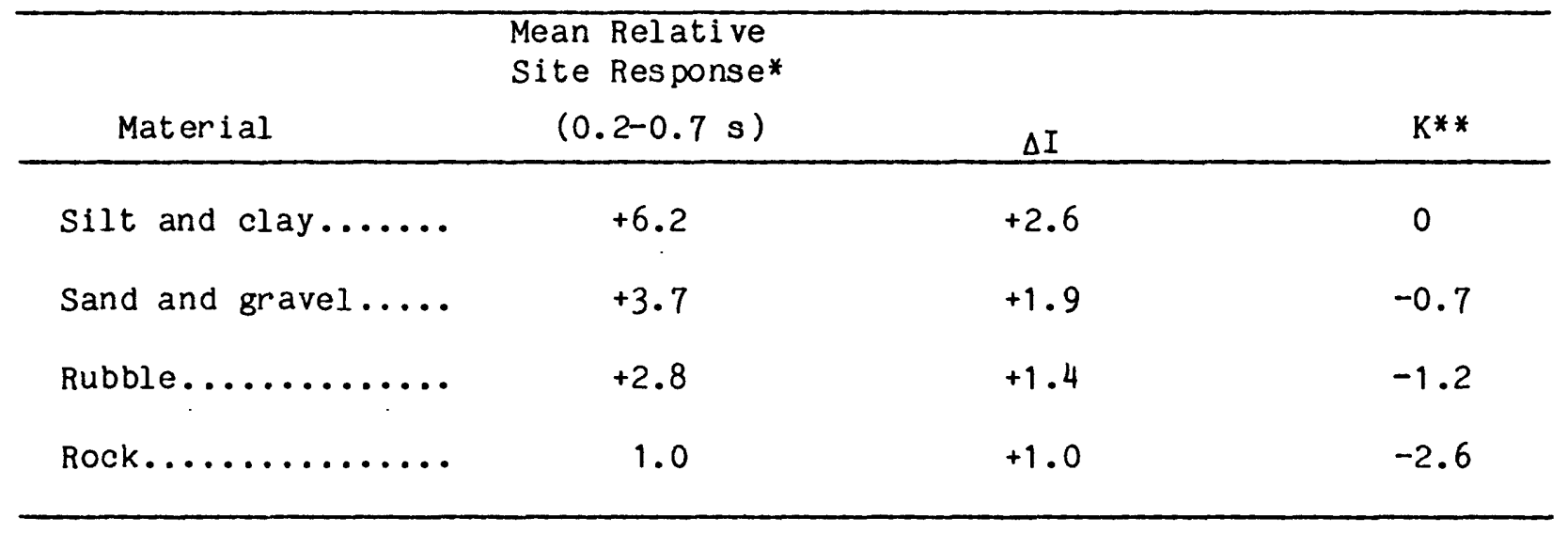

* The Mean Relative Response for the period band from 0.2-0.7 sec was computed by Rogers and others (1984). The Mean Relative Response is the log normal mean of the mean spectral ratios in the ground motion period band $0.2-0.7$ sec. ${ }^{*} \mathrm{~K}$ is the correction term for intensity attenuation in equation $1 . \mathrm{K}$ reduces the simulated intensity at a site if that site is underlain by sand and gravel, rubble, or rock. No correction to equation 1 is needed (i.e., the correction is zero) if the site is underlain by silt and clay. 
It has been found (Borcherdt, 1970; Borcherdt and others, 1975) that a factor of two in mean spectral velocity response level corresponds roughly to a change of about one Modified Mercalli (MM) intensity unit. A similar relationship has been shown to hold for peak velocity. For values of intensity up to intensity $X$, Rosenblueth (1964) found that the relationship $I=\log 14 \mathrm{v} / \log 2$ (where $I$ is MM intensity and $v$ is the maximum ground velocity in $\mathrm{cm} / \mathrm{sec}$ ) was a reasonable approximation. Based on the above relationships, the amplification of intensity with respect to rock of each of the three lithologic categories selected by Rogers and others (1984) was approximated. The lithologic categories are listed in Table 3, together with their mean relative response in the period band $0.2-0.7 \mathrm{sec}$, the incremental increase of intensity with respect to rock $(\Delta I)$ and the $K$ factor in equation 1. Since the maximum intensity $I_{0}$ in equation 1 is assumed to occur on sand and silt, the $\mathrm{K}$ site correction is zero for sites with this category of lithology. For sites located on the other lithologic categories (sand and gravel, rubble, and rock) the $\mathrm{K}$ factor is a negative correction in the intensity attenuation relationship.

In summary, the distribution of intensities for the scenario earthquakes listed in Table 2 were obtained using equation 1 with the intensity correction factors listed in Table 3. Typical intensity attenuation curves for silt and clay, sand and gravel, rubble and rock are shown in Figure 3. The site amplification factor of Rogers and others (1984) together with the associated $K$ values for equation 1 , and the fault rupture lengths used in the ground motion simulations are shown in Figures 4,5 and 6 . The simulated distribution of $M M$ intensity for a portion of the area shaken by a $M_{S}=7.5$ earthquake on the wasatch segment is shown in Figure 7. An isometric view of the same simulated ground shaking is shown in Figure 8 . 




FIGURE 3. Intensity attenuation curves.

$$
\left(I_{0}-I\right)=10 \exp \{-4.21873+0.604413 \ln (x)\}+K
$$

where $I_{0}$ is the maximum MM intensity for each earthquake (Table 1), I is the intensity at a distance $x$ from the surface fault rupture and $K$ is a correction for site response (Table 2). 


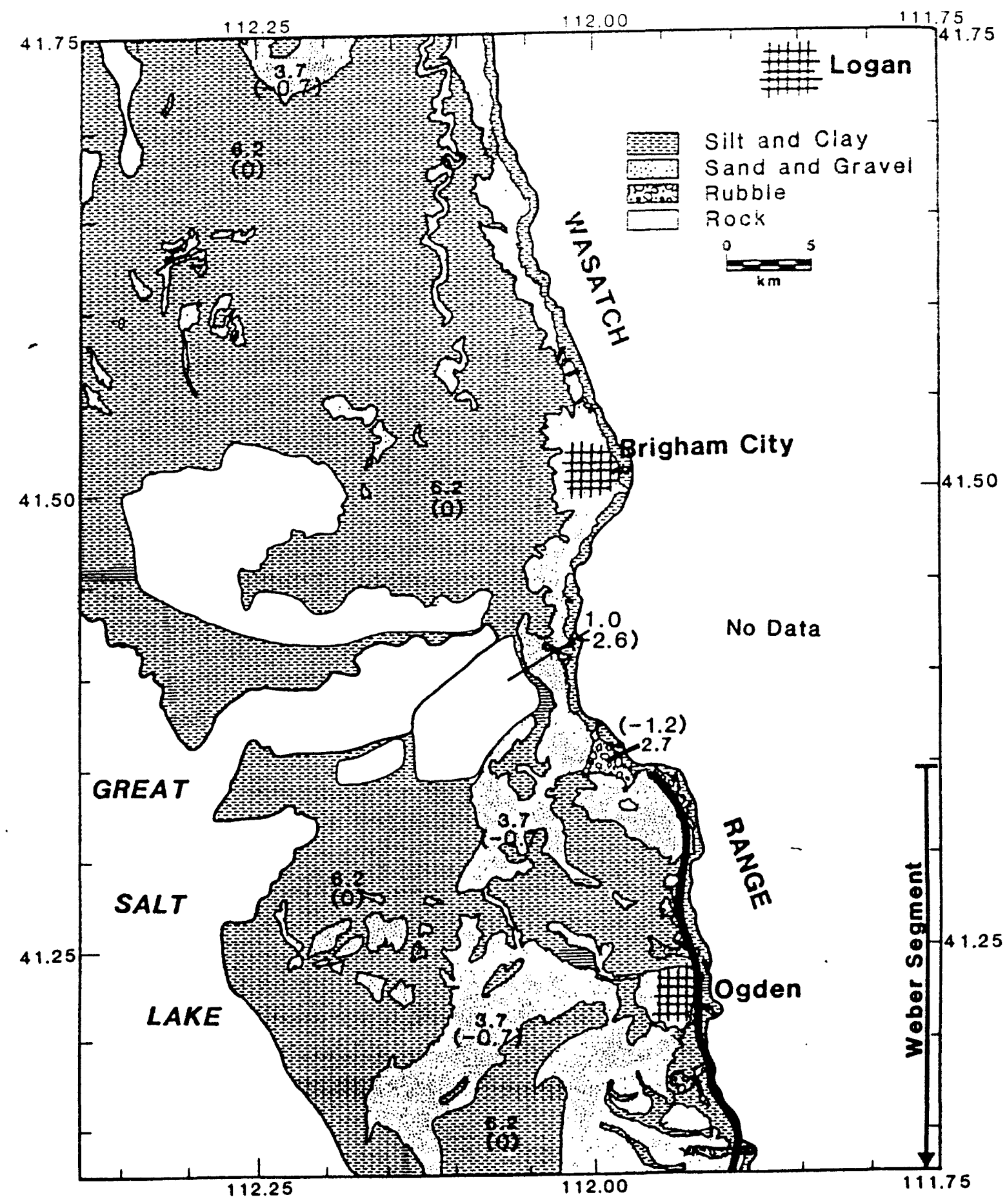

FIGURE 4. Distribution of site response amplification factors (adopted from Rogers, 1984). Intensity corrections (K) used in conjunction with equation 1 (in text) are shown in parentheses. The fault segments assumed to rupture in the simulated earthquakes are shown by heavy black lines. Solid black circles mark the center of rupture on each fault segment. Assumed lengths of ruptiure for each magnitude earthquake are given in Table 2 . 




FIGURE 5. Distribution of site response ampi ification factors (adopted from Rogers, 1984). Intensity corrections (K) used in conjunction with equation 1 (in text) are shown in parentheses. The fault segments assumed to rupture in the simulated earthquakes are shown by heavy black lines. Solid black circles mark the center of rupture on each fault segment. Assumed lengths of rupture for each magnitude earthquake are given in Table 2. The heavy dashed I ine represents the fault rupture length for a $M_{S}=7.5$ earthquake on a hypotherical fall located approximately along the west flank of the Oquirrh Mountains. 


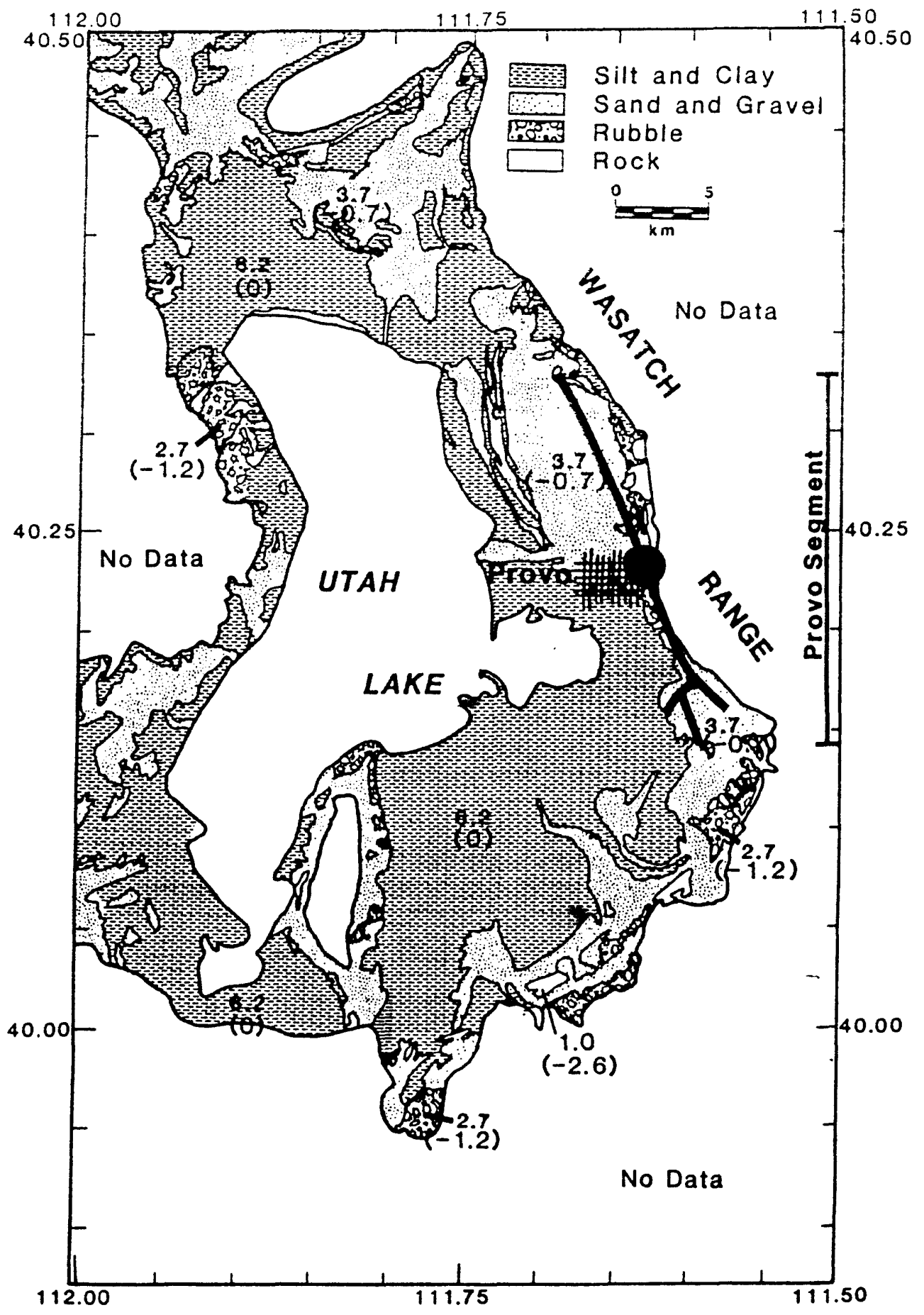

FIGURE 6. Distribution of site response amplification factors (adopted from Rogers, 1984). Intensity corrections (K) used in conjunction with equation 1 (in text) are shown in parentheses. The fault segments assumed to rupture in the simulated earthquakes are shown by heavy black lines. Solid black circles mark the center of rupture on each fault segment. Assumed lengths of rupture for each magnitude earthquake are given in Table 2. 


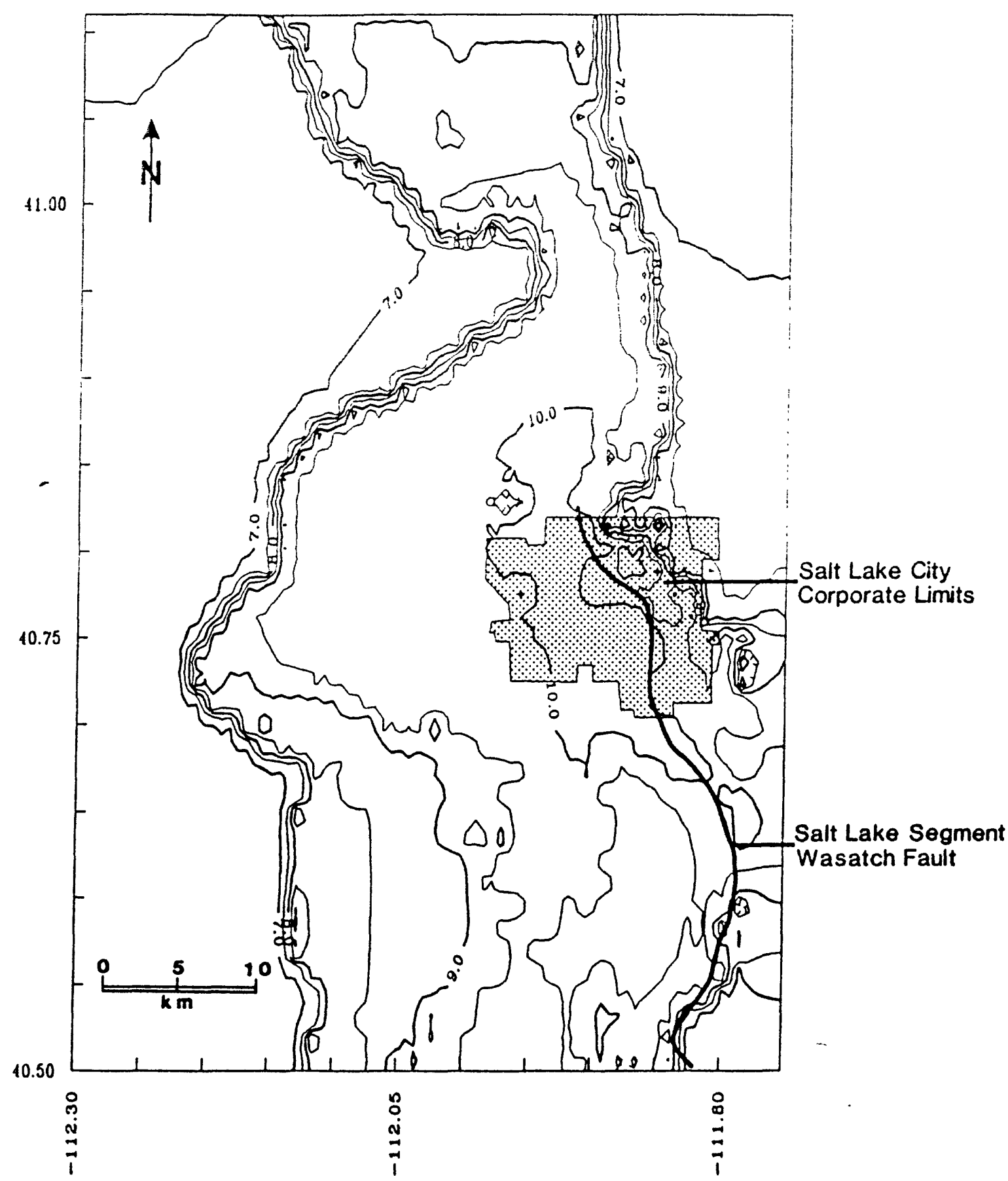

FIGURE 7. Isoseismal map for a simulated $M_{S}=7.5$ earthquake on the Salt Lake segment of the wasatch fault. The intensities have been slightly smoothed. The irregular polygon is the corporate limits of salt Lake City, and the emphasized Iine segment is the salt Lake segment of the Wasatch fault. 


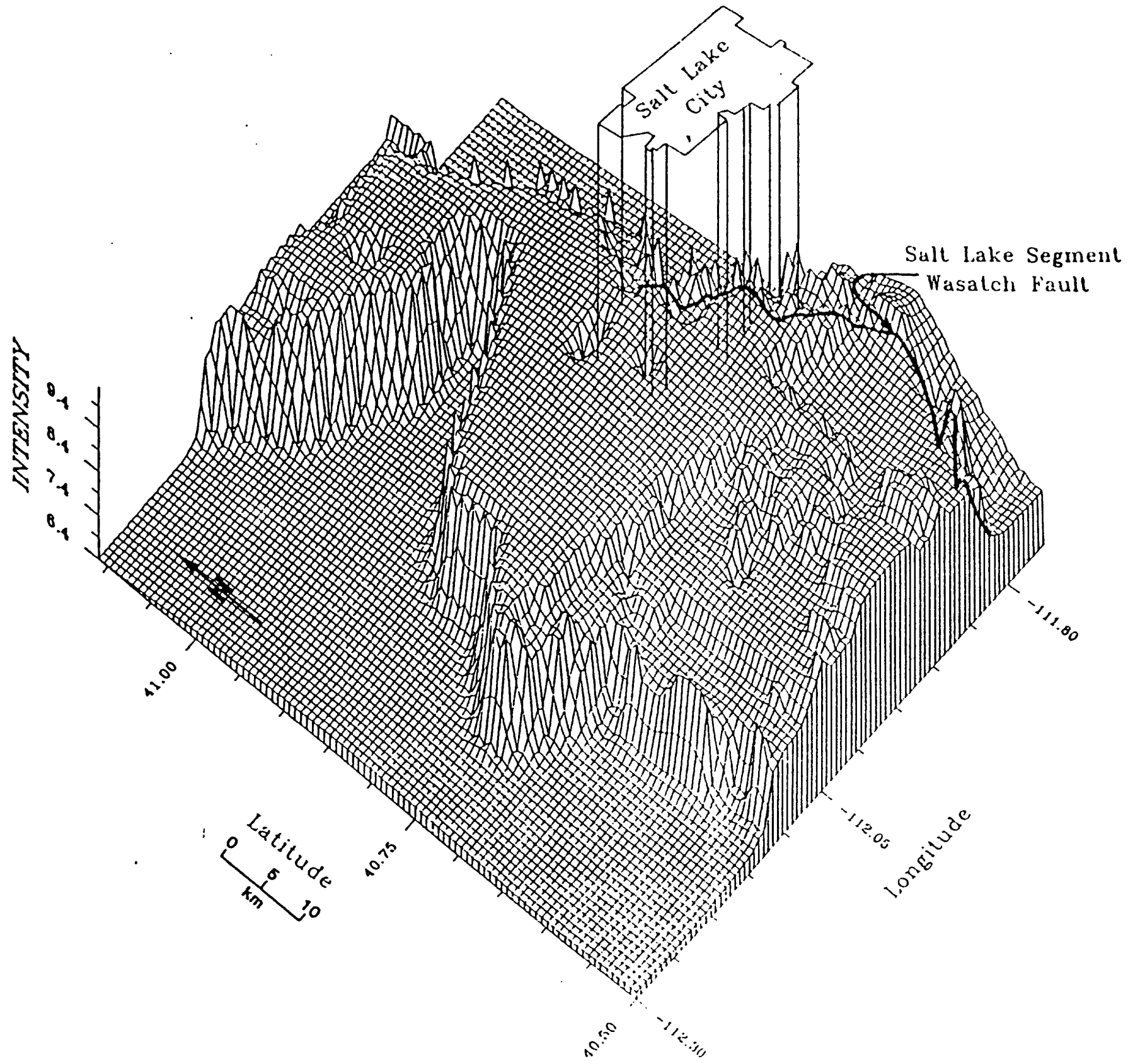

FIGURE 8. Isometric view of distribution of MM intensity for a simulated $M_{S}=7.5$ earthquake on the Salt Lake segment of the wasatch fault. The heavy black line marks the wasatch fault. The data are the same as shown in Figure 7. 
The probabilistic hazard model used to estimate losses in the Wasatch Front Urban Corridor is essentially the model described in Algermissen and others (1982). Earthquakes are exponentially distributed with regard to magnitude and randomly distributed with regard to time in this model. The exponential magnitude distribution is an assumption based on empirical observation. The distribution of earthquakes in time is assumed to be Poissonian. The model has essentially four parts (Figure 9). These are: a seismic source model that serves to define the spatial distribution earthquakes within the region of concern (Figure 9-A); (2) occurrence model of earthquakes that describes the recurrence of events in time within the seismic source zones (Figure 9-B). In practice the magnitude distribution of earthquakes described by the relationship $\log _{10} \mathrm{~N} /$ unit area $=a-b m$ where $N=$ number of earthquakes $>\mathrm{m}$, and $\mathrm{a}$ and $\mathrm{b}$ are constants determined for each source zone; (3) a ground motion attenuation model which is a description of the manner in which earthquake ground motions decrease with distance from an earthquake source for various magnitude levels (Figure 9-C); and (4) a probability model for calculating the expected maximum amplitude of ground motion within a given period of time corresponding to a chosen probability level for a number of individual sites in the region (Figure 9-D and 9-E). Figure 9-D shows an idealized cumulative distribution function for intensity at a site and 9-E depicts the probability of occurrence (for a Poisson model) of an expected maximum intensity I for various exposure times $T$. The seismic source zones used in the model differ from those of Algermissen and others (1982) in that the eight fault segments described by Machette and others (1988) have been assigned individual rates of occurrence of large earthquakes $\left(M_{S}=6.4-7.6\right)$ based on new paleoseismic data. A more complete description of the model used may be found in Algermissen and others 

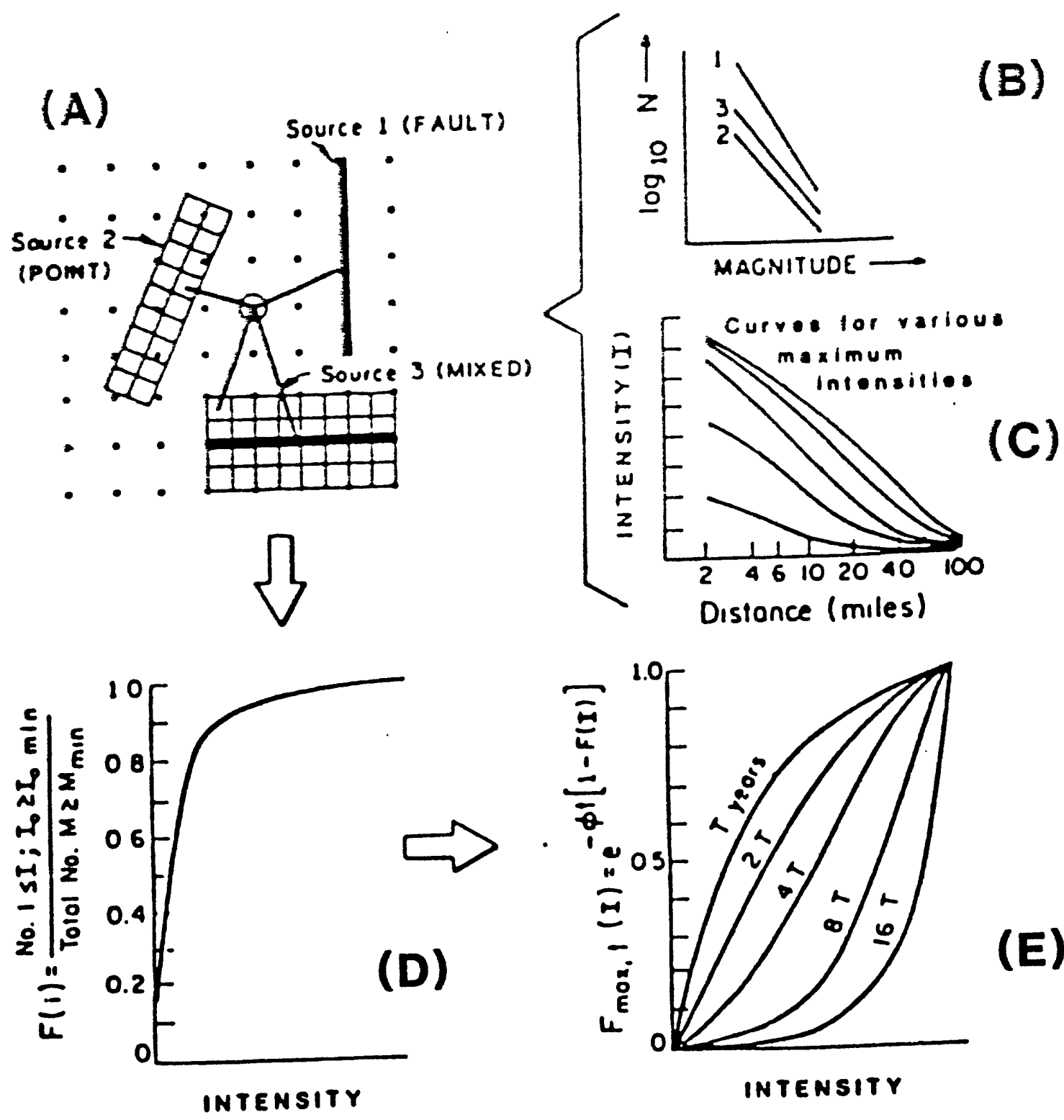

(E)

FIGURE 9. Schematic illustrating the model for calculation of probabilistic maximum MM intensity. 
(this volume) where a number of ground motion models for the Utah area are discussed. The attenuation of MM intensity used in the probabilistic model is that given in equation 1 , the same attenuation as used for the deterministic (scenario) earthquake modeling. The maximum MM intensity in a 50 year pericd with a 10 percent chance of exceedance is for a portion of the study area as shown in Figure 10 and an isometric view of the same ground shaking is shown in Figure 11. As an example, probabilistic intersity maps of the entire four county area can be found in the paper by Algermissen and others in this volume. Inventory Development

The inventory development consists of two parts: (a) inventory of dwellings; Classes IA, IB, VB and VE (Table 1); and (2) all other classes of buildings .

Buildings other than dwellings: The inventory for all buildings other than dwellings is based on inventory developed by Steinbrugge (1986). The non-dwelling inventory includes structures valued at $\$ 1,000,000$ and over at the time of construction, not their replacement value at 1985 levels.

" Other than in the largest cities, namely, Salt Lake City, Ogden and Provo, and some sections of Salt Lake County, most of the outlying areas have major buildings costing in excess of $\$ 1,000,000$ generally located in either shopping malls, shopping centers, or Church of Jesus Christ of Latter Day Saints (L.D.S.) church complexes. Malls are defined as large structures with several entries and exits housing major department stores and many smaller stores ail under one roof structure. Shopping centers are similar, consisting of some major buildings, but are not part of a single covered complex. 


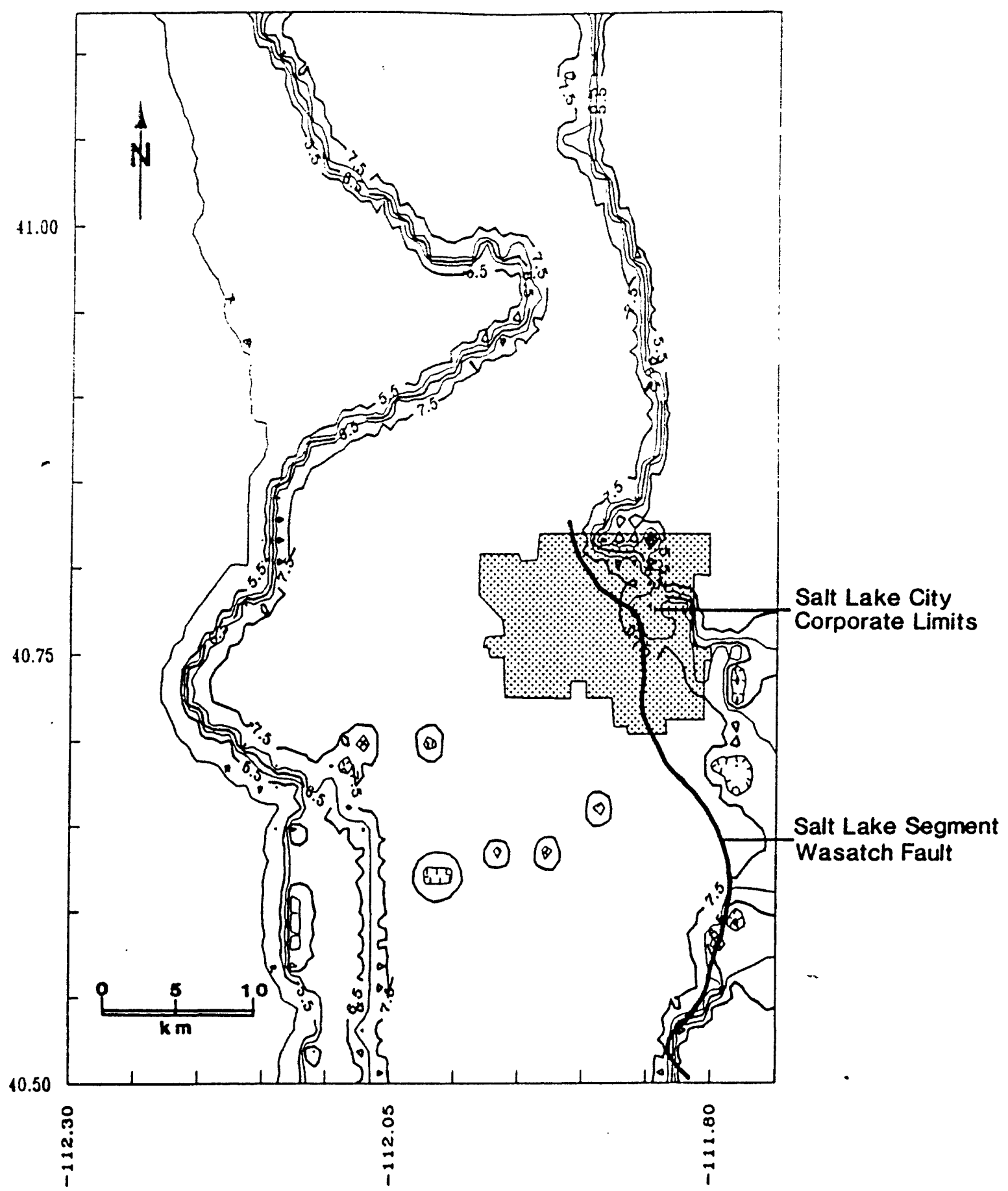

FIGURE 10. Distribution of the maximum MM intensity in the salt Lake area in 50 years with a 10 percent chance of exceedance. 


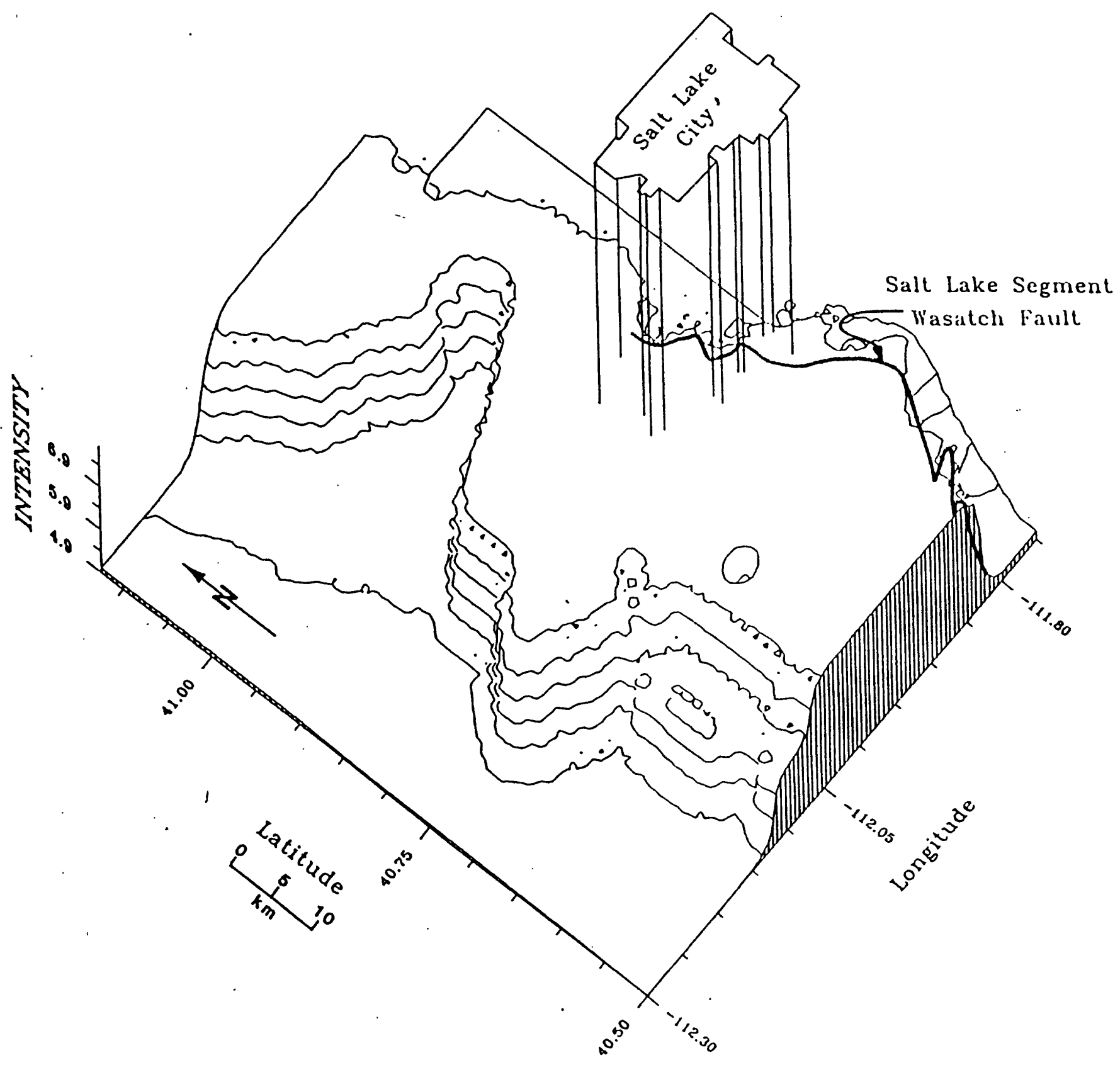

FIGURE 11. Vulnerability relationships used in this study (Steinbrugge, 1986). The inflection points of the curves are tabulated in Table 6. 
These malls and shopping centers are generally located on or near major state roads and are usually located near the intersection of two major traffic routes. While the malls are few in number, there are numerous shopping centers. Only a few of these shopping centers have structures exceeding $\$ 1,000,000$. Most of the buildings are small stores and shops. These centers are located in residential areas where few other major structures exist. The remote sections of the study area are unique in that usually the only construction exceeding $\$ 1,000,000$ consists of church structures erected by the Church of Jesus Christ of Latter Day Saints (L.D.S.) These buildings are generally of high quality mixed construction designed to resist major seismic forces. They occur in most of the small outlying communities and farming areas where no other large structures exist. Most are in residential areas. There are literally hundreds of such buildings within the study area with many costing in excess of $\$ 1,000,000$. Most of these structures are of recent construction and are included in the total square footage areas of Table 4.

Schools, government buildings and heavy industrial complexes are not included in the inventory.

A number of data sources were used to derive the non-dwelling inventory. The major sources of data were:

1. Building permit records

2. L.D.S. Church records

3. Sanborn maps

4. Reports to the F. W. Dodge-McGraw Hill Company, published as building statistics

5. Census tract maps

6. Field investigation. 
Possibly the most effective method of locating, listing and describing buildings exceeding $\$ 1,000,000$ in value not listed in county or other records was extensive field investigation. Records for much of the four counties are incomplete and considerable on-site inspection was required. Many of the available records 1 ist buildings that have been demolished and consequently must not be included in the inventory. The location of these buildings can generally only be determined by field irspection.

A summary of the building inventory for all classes of buildings other than dwellings is given in Table 4. Replacement cost values for non-dwelling buildings were taken from Steinbrugge (1986) and are based on a review of actual costs of replacement in Utah in 1985. The replacement costs per square foot are summarized in Table 5 .

Dwelling Inventory: The inventory of housing is taken as of July 1, 1985 for consistency with the non-dwelling inventory. The dwelling or housing inventory was constructed from the 1980 Census of Housing as published in Bureau of Census $1983 \mathrm{a}$ and $1983 \mathrm{~b}$ augmented by other information from the Bureau of Census unpublished data and the various Boards of Fiealtors and county and city planning commissions. Details of these calculations are given below.

First, Tooele County and house trailers and other non-permanent, yearround housing units were not included in this inventory. Tooele County, although included by the Census in the Salt Lake Standard Metropolitan Statistical Area (SMSA), was excluded because it is both sparsely populated and information is difficult to obtain especially for valuations. Trailers were excluded from the counts simply because the vulnerability of house trailers is difficult to quantify. This will have the effect of making total calculated losses slightly less conservative than the actual ones. There were 
TABLE 4. Building Classes other than Dwellings

(Building Areas in Square Feet $x$ 1,000)

Summary of Data Compiled from all Sources for the Four County Study Area

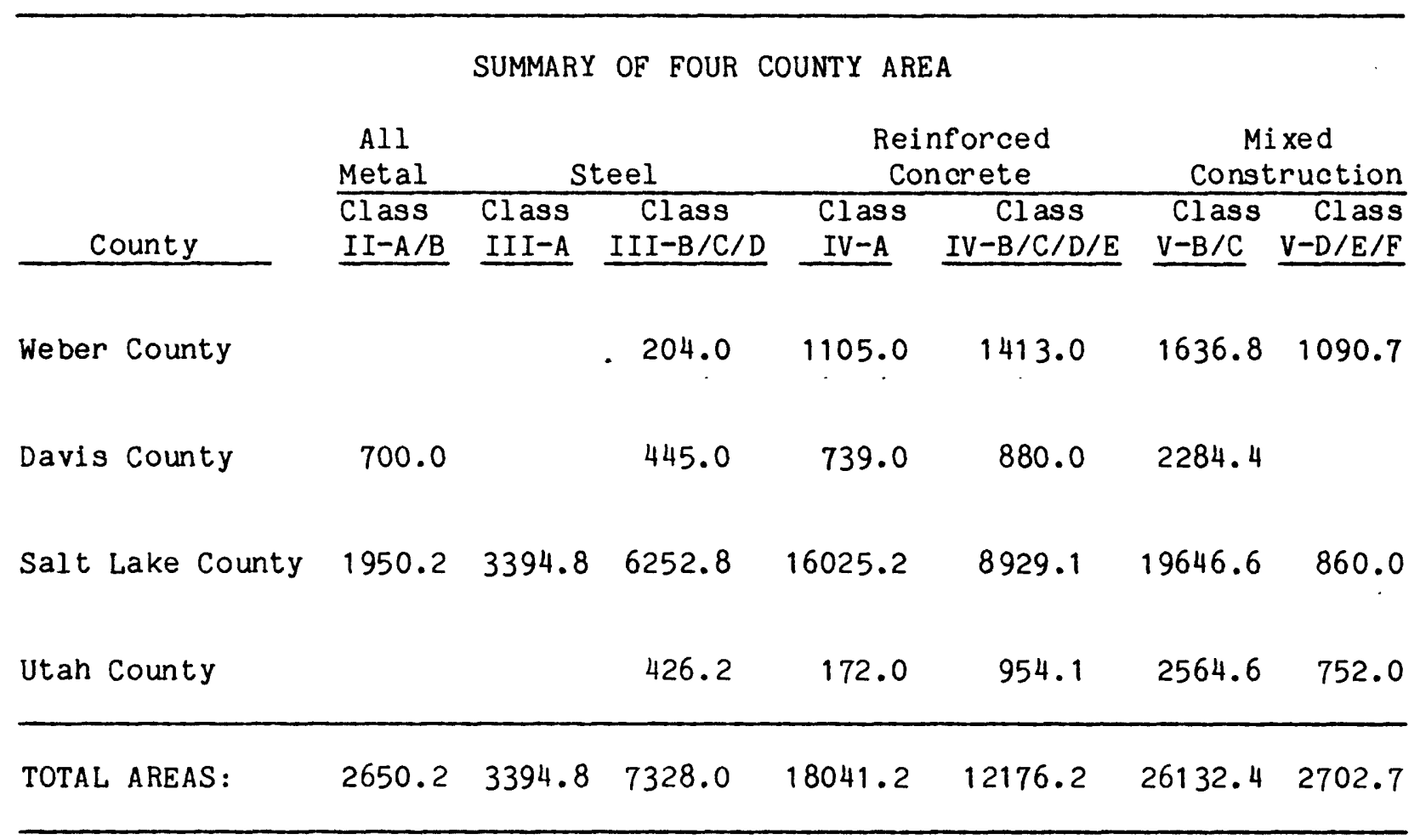


TABLE 5. Replacement Cost (1985) per Unit Area

for Building Classes other than Dwellings (Steinbrugge, 1986)

\begin{tabular}{|c|c|}
\hline Class & Price/ft ${ }^{2}$ \\
\hline I & $\$ 55$ \\
\hline II & 41 \\
\hline III & 71 \\
\hline IV & 72 \\
\hline V & 63 \\
\hline
\end{tabular}


9,229 trailers in the Salt Lake SMSA and 2,153 in the Provo SMSA in 1980 as compared with 223,097 and 42,104 respectively for single family dwellings, thus making the error small.

A dwelling or housing unit, loosely defined as a self-contained structure or partial structure serving as a year-round dwelling for a family, were divided into two classes by the number of housing units per structure; those with four or less units per structure and those with five or more. The former constituting mostly single family detached dwellings and probably large, older houses which have been divided into apartments as well as the more modern town houses. The larger buildings comprise mostly apartments in the 10-49 units per building category. The apportionment between these two classes was made by using the ratios given in Bureau of the Census in 1983a and 1983b for 1980. Since the amount of housing erected between 1980 and 1985 is smail these ratios should still be fairly accurate.

The total number of housing units in each Census tract was updated to 1985 by obtaining the number of building permits issled in the years 1980 to 1984 from the Census Bureau and, assuming that building was uniform over each county, pro-rating that number over the Census tracts. Housing units are further divided into wood frame and masonry construction. These are listed as either Class I or Class V of the Building Classification given in Algermissen and others (1978, Table 1). Unfortunately, no good estimate of the ratio of wood frame to masonry housing units is available from the Census or elsewhere. In this case, the figure of approximately $60 \%$ masonry for the region was used after consultation with staff members of the Salt Lake Planning Commission. 
All housing units in the masonry category were then subdivided into Class $V-E$ or $V-B$ depending upon whether they were built before or after 1950 respectively. Again, the ratios are the ones given by the Census by county for 1980. No consideration was given to brick veneer on wood frame construction; it was assumed that all of the veneer dwellings were constructed after 1949 and had vulnerability similar to Class V-B structures. The replacement cost of individual units was determined in the following manner. For 1-4 unit structures, the current value was obtained from the salt Lake Board of Realtors who have divided Salt Lake County into 12 regions. An average sale price in 1985 for each of the 12 regions was obtained. The Ogden Board of Realtors has divided Davis and Weber Counties into 18 regions and the Provo Board of Realtors provided similar results in Utah County. Seventy-five percent of the average cost of dwellings in each of the areas sampled was taken as the replacement cost, 25 percent being taken as the land value.

In the case of structures with five or more units, the area of the average unit was taken to be 950 square feet, a figure considered average in the estimation of each of the Realty Boards consulted. The price of wood frame structures was taken to be $\$ 55$ per square foot and the masonry units $\$ 63$ (Steinbrugge, 1986; Table 5). Any units in Class III or IV structures will be slightly underpriced by this calculation but damage will be calculated as if they were Class $V-B$ which would be higher thus having a compensating effect. In addition to obtaining a value for all housing in a tract, it is necessary to locate the housing spacially by assuming it to exist at a "ceriter of housing." The Census gives a center of population for each tract which can reasonably be taken to be the center of housing. In addition, because of the irregular boundaries of many municipalities in the four counties, there are many tracts which are "split" between a number of municipalities. This 
necessitated combining the partial tracts by using means weighted by numbers of housing units. The centers of housing are expressed in geographic coordinates. The replacement value for all classes of buildings (used to estimate losses) is taken as the total cash value required to fully repair or rebuild in kind any building of a particular class.

Vulnerability

Vulnerability as used in this study is taken to mean the relationship between percent loss and Modified Mercalli (MM) intensity. Percent loss is defined to mean the average percentage of the total actual cash value required to fully repair or rebuild in kind any building of a particular class experiencing ground motion represented by a particular degree of the MM intensity scale.

The two sets of vulnerability relationships used are 1) those developed by Steinbrugge (1979), further reviewed by Steinbrugge in 1986, and 2) those developed by the Applied Technology Council (ATC) as given in ATC-13 (1985). The Steinbrugge vulnerability relationships are shown graphically in Figure 11 and numerically in Table 6. It should be clearly understood that both the vulnerability relationships used are for ground shaking related damage only.

\section{LOSS CALCULATIONS}

Losses were calculated in a totally automated manner on microcomputers. The only exception to the above statement is the use of hand digitization of geological features such as areas of varying soil amplification and fault traces. These exceptions are still less time consuming than previously used methods. The flow of the calculations is as follows:

Calculation of losses to dwellings: The inputs are the co-ordinates of the centers of housing for the 229 Census tracts in the four county urban area; a map of the various surficial materials underlying the urban corridor; 
TABLE 6. Coordinates of Loss-Intensity Curves for Figure 11 Steinbrugge (1986)

\begin{tabular}{|c|c|c|c|c|c|c|c|c|}
\hline \multirow{2}{*}{$\begin{array}{c}\text { Building } \\
\text { Class } \\
\end{array}$} & \multicolumn{2}{|c|}{ Point A } & \multicolumn{2}{|c|}{ Point $B$} & \multicolumn{2}{|c|}{ Point $C$} & \multirow{2}{*}{$\frac{\text { Points D }}{\% \text { Loss }}$} & \multirow{2}{*}{$\frac{D \& E}{M M}$} \\
\hline & $\%$ Loss & MM & \% LOS & $\overline{M M}$ & $\%$ Loss & $\underline{M M}$ & & \\
\hline$I-A$ & 0 & V & 0.80 & VI & 8.00 & IX & 9.00 & $X / X I I$ \\
\hline$I-B$ & 0 & V & 0.80 & VI & 8.00 & IX & 9.00 & $X / X I I$ \\
\hline II-A & 0 & VI & 0.60 & VII & 6.00 & IX & 6.50 & $X / X I I$ \\
\hline$I I-B$ & 0 & VI & 0.80 & VII & 8.00 & IX & 9.00 & $X / X I I$ \\
\hline III-A & 0 & VI & 1.00 & VII & 10.00 & IX & 12.00 & $X / X I I$ \\
\hline III-B & 0 & V & 1.75 & VI & 17.50 & IX & 20.00 & $\mathrm{X} / \mathrm{XII}$ \\
\hline III-C & 0 & VI & 1.25 & VII & 12.50 & IX & 15.00 & X/XII \\
\hline III-D & 0 & V & 1.75 & VI & 17.50 & IX & 20.00 & $\mathrm{X} / \mathrm{XII}$ \\
\hline IV $-A$ & 0 & VI & 1.25 & VII & 12.50 & IX & 15.00 & $X / X I I$ \\
\hline$I V-B$ & 0 & V & 2.50 & VI & 25.00 & IX & 27.50 & $X / X I I$ \\
\hline$I V-C$ & 0 & VI & $1: 75$ & VII & 17.50 & IX & $20: 00$ & $X / X I I$ \\
\hline$I V-D$ & 0 & V & 3.00 & VI & 30.00 & IX & 32.50 & $X / X I I$ \\
\hline$I V-E$ & 0 & V & 2.75 & VI & 27.50 & IX & $30: 00$ & $X / X I I$ \\
\hline$V-A$ & 0 & VI & 0.75 & VII & 7.50 & IX & 9.00 & $X / X I I$ \\
\hline$V-B$ & 0 & VI & 1.25 & VII & 12.50 & IX & $14: 00$ & $X / X I I$ \\
\hline$V-C$ & 0 & V & 1.75 & VI & 17.50 & IX & 20.00 & $\mathrm{X} / \mathrm{XII}$ \\
\hline$V-D$ & 0 & V & 2.25 & VI & $22: 50$ & IX & 25.00 & $\mathrm{X} / \mathrm{XII}$ \\
\hline$V-E$ & 0 & V & 10.00 & VI & 100.00 & IX & Not app & licable \\
\hline$V-F$ & 0 & IV & $10: 00$ & V & $100: 00$ & IX & Not app & 1 icable \\
\hline
\end{tabular}


a map of the wasatch fault zone; numbers of housing units in the various construction classes in each tract along with estimates of value; floor areas of non-dwelling structures in each tract and an estimate of value; a function giving the attenuation of intensity with respect to distance from a fault rupture; and a set of vulnerability curves giving losses as a function of intensity.

The two maps are first digitized and the points converted to the state Plane (North) projection, in this case, a Lambert Conformal Conic projection with standard parallels at $40^{\circ} 43^{\prime} \mathrm{N}$ and $41^{\circ} 47^{\prime} \mathrm{N}$ with a sentral meridian at $111^{\circ} 30^{\prime} \mathrm{W}$. The centers of housing are transformed into the same projection. The distances from the active fault segment to each center of housing is then computed. The distance is measured along the normal from the housing centers to the fault, or for housing centers beyond the ends of the active fault segment, the lesser of the two distances from center to end-points of the segment. Both the centers of housing and the soil amplification map are then plotted. A utility program is then used to produce a list of tract identification numbers against the soil types underlying each center.

As previously explained, each soil type and earthquake magnitude corresponds to a specific maximum intensity, $I_{0}$, in equation (1), repeated here for convenience,

$$
\left(I_{0}-I\right)=10 \exp \{-4.21873+0.604413 \ln (x)\}+K
$$

where $x$ is the distance from fault to housing center in kilometers. Once a list of tracts, distances, and $I_{0}$ 's has been compiled, using equation (1), the intensity at each housing center, I, is calculated and rounded to the nearest 0.1 intensity unit. 
The only step not yet completely automated in the calculation of losses is the one that finds whether or not the fault trace intersects the tract. In the present calculation, this is determined by overlaying a tract map giving actual boundaries on the fault map and flagging the intersected tracts by hand thus making a list to augment the one giving tract identification and intensity .

The numbers of units in each tract that belong to each of the four dwelling construction classes are then calculated. Total numbers of housing units are obtained from Bureau of the Census $1983 c$ on magnetic tape. The ratios of 1 to 4 dwelling units per structure to ones with 5 or more dwelling units per structure were obtained from Bureau of Census 1983a and 1983b as were the ratios of pre-1950 housing units to post-1950 units. The total units added from 1980 to 1985 was obtained from the Census' unpublished records of building permits. The total units were adjusted to reflect 1985 numbers then divided into wood frame and masonry (assuming $60 \%$ masonry) and further apportioned into large and small structures. The masonry structures were further divided into Classes $V-E$ and $V-B$ depending upon whether the unit was built before or after 1950.

Dwelling values for 1985 were then calculated. For all structures with one to four units, the values for each dwelling unit is the one given by the various Boards of Realtors in the areas specified by them. That is to say, the census tracts were allotted to each of the realtor's areas, the latter always being larger than the former; no distinction was made jetween wood frame or masonry.

For all housing in structures with 4 or fewer units an arbitrary 25\% of the value was subtracted to account for the value of the land which, of course, is not generally damaged. 
The loss calculation for housing units were computed using the vulnerability curves of Steinbrugge (1986) and vulnerability curves developed by the Applied Technology Council (1985). This comparison provides some degree of sensitivity analysis with regard to vulnerability. As a special case, those tracts where the fault trace passes through the tract, total destruction due to ground disuption was assumed to occur on a path 50 meters wide along the fault. A typical tract has a dimension of about $1 \mathrm{~km}$ resulting in $5 \%$ of the tract, on average, experiencing $100 \%$ loss. This part of the loss was computed on the total valuation including land. Values for non-dwelling structures were computed by multiplying the area of structures in each construction class by the 1985 value per unit area given by Steinbrugge (1986). These replacement costs are given in Table 5 .

Calculation of losses to non-dwellings: Losses for non-dwelling structures were computed using only the Steinbrugge (1986) vulnerability relationships since there were no comparable Applied Technology Council (1985) ones for the Wasatch urban region.

Summary of Loss Estimations: The earthquake loss estimates for all of the scenario earthquakes and the expected maximum losses in a 50 year period with a 10 percent chance of exceedance are listed in Tables 7 through 20 . The loss estimates are organized in the following manner:

1. Tables 7-16: Losses in the four county area for $M_{S}=7.5,6.5$ and $M_{L}=5.5$ scenario earthquakes on the Weber, Salt Lake and Provo segments of the wasatch fault and for an $M_{S}=7.5$ earthquake striking north-south to the west of Salt Lake City located approximately on the west flank of the Oquirrh Mountains. 
TABLE 7. SUMMARY OP ESTIMATED LOSSES, MAXIMUM WEBER SEGMENT EARTHQUARE $\left(M_{s}=7.5\right)$

Losses in the Four County Area

Number

$\begin{array}{lc}\text { Value } & \text { Losses }^{1} \\ \$ \times 10^{6} & \$ \times 10^{6}\end{array}$

Losses $^{2}$ $\$ \times 10^{6}$

Dwellings

Wood Frame

1-4 units (Class IA) 122,695

$6,308.6$

693.4

497.6

$\geq 5$ units (C1ass IB) 21,824

$1,140.3$

129.5

88.2

Masonry (Classes VB \& VE)

$1-4$ units

184,042

$9,462.9$

1848.7

2946.9

$\geq 5$ units

32.736

$1,959.2$

438.1

761.0

Subtotals

361.296

$18,871.0$

3109.7

4293.7

Non-dwellings

Wood Frame (Class IB)

40.1

3.5

All-metal (Class II)

108.5

8.6

Steel Frame (Class III)

761.3

112.1

Concrete Frame (Class IV)

$2,175.7$

411.1

Mixed Construction (Class V)

$1,782.3$

349.5

Subtotals

$4,867.9$

884.8

Totals

$23,738.9$

5178.5

1 Losses computed using vulnerability relationships developed by the Applied Technology Council (1985).

2 Losses computed using the vulnerability relationships shown in Figure 11 and Table 6 . 
TABLE 8. SUMMARY OF ESTIMATED LOSSES,

\section{MAXIMUM SALT LAKE SEGMENT EARTHQUAKE $\left(\mathrm{H}_{\mathrm{s}}=7.5\right)$}

Losses in the Four County Area

Number

$\begin{array}{lc}\text { Value } & \text { Losses } \\ \$ \times 10^{6} & \$ \times 10^{6}\end{array}$

Losses $^{2}$

$\$ \times 10^{6}$

Dwellings

Wood Frame

1-4 units (Class IA) 122,695

$6,308.6$

834.9

550.6

$\geq 5$ units (Class IB) 21,824

$1,140.3$

171.2

103.0

Masonry (Classes VB\& VE)

$1-4$ units $\quad 184,042$

$9,462.9$

$2,131.9$

$3,101.9$

$\geq 5$ units

32,736

$1,959.2$

535.0

799.5

Subtotals

361,296

$18,871.0$

$3,673.0$

$4,555.0$

\section{Non-dwellings}

Wood Frame (Class IB)

40.1

3.6

Al1-metal (Class II)

108.5

8.5

Steel Frame (Class III)

761.3

120.7

Concrete Frame (Class IV)

$2,175.7$

423.8

Mixed Construction (Class V)

$1,782.3$

366.3

Subtotals

$4,867.9$

922.9

Totals

$23,738.9$

$5,477.9$

1

Losses computed using vulnerability relationships developed by the Applied Technology Council (1985).

2 Losses computed using the vulnerability relationships shown in Figure 11 and Table 6. 
TABLE 9. SUMMARY OF ESTIMATED LOSSES,

MAXIMUM EARTHQUARE $\left(M_{B}=7.5\right) 50$ KM WEST OF SALT LARE CITY

Losses in the Four County Area

$\begin{array}{cccc}\text { Number } & \text { Value } & \text { Losses }^{1} & \text { Losses }^{2} \\ & \$ \times 10^{6} & \$ \times 10^{6} & \$ \times 10^{6}\end{array}$

Dwellings

Wood Frame

1-4 units (Class IA) 122,695

$6,308.6$

481.2

453.4

$\geq 5$ units (Class IB) 21,824

$1,140.3$

95.4

83.6

Masonry (Classes VB\& VE)

1-4 units

184,042

$9,462.9$

$1,169.4$

$2,801.4$

$\geq 5$ units

32,736

$1,959.2$

364.5

742.0

Subtotals

361,296

$18,871.0$

$2,110.5$

$4,080.4$

Non-dwellings

Wood Frame (Class IB)

40.1

3.3

Al1-meta1 (Class II)

108.5

8.2

Steel Frame (Class III)

761.3

108.5

Concrete Frame (class IV)

$2,175.7$

388.9

Mixed Construction (Class V)

$1,782.3$

335.6

Subtotals

$4,867.9$

844.5

Totals

$23,738.9$

$4,924.9$

1

Losses computed using vulnerability relationships developed by the Applied Technology Council (1985).

2 Losses computed using the vulnerability relationships shown in Figure 11 and Table 6 . 
TABLE 10. SUMMARY OF ESTIMATED LOSSES,

Losses in the Four County Area

Number

Value

$\$ \times 10^{6}$

Losses $^{1}$

Losses $^{2}$

$\$ \times 10^{6}$

Dwe11ings

Wood Frame

1-4 units (Class IA) 122,695

$6,308.6$

409.9

426.5

$\geq 5$ units (Class IR) 21,824

$1,140.3$

82.1

81.1

Masonry (Classes VB\& VE)

1-4 units

184,042

$9,462.9$

$1,273.4$

2.567 .6

$\geq 5$ units

32,736

$1,959.2$

324.7

707.6

Subtotals

361,296

$18,871.0$

$2,090.1$

$3,782.8$

Non-dwellings

Wood Frame (Class IB)

40.1

3.0

All-metal (Class II)

108.5

6.4

Steel Frame (Class III)

761.3

98.3

Concrete Frame (Class IV)

$2,175.7$

338.8

Mixed Construction (Class V)

$1,782.3$

304.9

Subtotals

$4,867.9$

751.4

Totals

$23,738.9$

$4,533.4$

Losses computed using vulnerability relationships developed by the Applied Technology Council (1985).

2 Losses computed using the vulnerability relationships shown in

Figure 11 and Table 6 . 
TABLE 11. SUMMARY OF ESTIMATED LOSSES, MODERATE WEBER SEGMENT EARTILUARE $\left(M_{s}=6.5\right)$

Losses in the Four County Area

$\begin{array}{cccc}\text { Number } & \text { Value } & \text { Losses }^{1} & \text { Losses }^{2} \\ & \$ \times 10^{6} & \$ \times 10^{6} & \$ \times 10^{6}\end{array}$

\begin{tabular}{|c|c|c|c|c|}
\hline \multicolumn{5}{|l|}{ Dwellings } \\
\hline \multicolumn{5}{|l|}{ Wood Frame } \\
\hline $1-4$ units (Class IA) & 122,695 & $6,308.6$ & 216.8 & 298.7 \\
\hline$\geq 5$ units (Class IB) & 21,824 & $1,140.3$ & 40.3 & 54.7 \\
\hline \multicolumn{5}{|c|}{ Masonry (Classes VB \& VE) } \\
\hline $1-4$ units & 184,042 & $9,462.9$ & 697.6 & $1,734.4$ \\
\hline$\geq 5$ units & 32,736 & $1,959.2$ & 169.2 & 478.9 \\
\hline Subtotals & 361,296 & 18.871 .0 & $1,123.9$ & $2,566.7$ \\
\hline
\end{tabular}

Non-dwellings

Wood Frame (Class IB)

40.1

2.3

Al1-metal (Class II)

108.5

5.2

Steel Frame (Class III)

761.3

65.7

Concrete Frame (Class IV)

$2,175.7$

253.1

Mixed Construction (Class V)

$1,782.3$

204.3

Subtotals

$4,867.9$

530.6

Totals

$23,738.9$

$3,097.3$

1 Losses computed using vulnerability relationships developed by the Applied Technology Council (1985).

2 Losses computed using the vulnerability relationships shown in Figure 11 and Table 6. 
TABLE 12. SUMMARY OF ESTIMATED LOSSES, MODERATE SALT LAKE SEGMENT EARTHQUAKE $\left(M_{\mathrm{s}}=6.5\right)$

\begin{tabular}{|c|c|c|}
\hline Number & $\begin{array}{l}\text { Value } \\
\$ \times 10^{6}\end{array}$ & $\begin{array}{c}\text { Losses }^{1} \\
\$ \times 10^{6}\end{array}$ \\
\hline
\end{tabular}

\section{Dwellings}

Wood Frame

1-4 units (Class IA) 122,695

$6,308.6$

327.0

394.4

$\geq 5$ units (Class IB) 21,824

$1,140.3$

67.8

77.0

Masonry (Classes VB \& VE)

$1-4$ units

184,042

$9,462.9$

$1,021.4$

$2,214.7$

$\geq 5$ units

32,736

$1,959.2$

273.1

631.7

Subtotals

361,296

$18,871.0$

$1,689.3$

$3,317.8$

Non-dwellings

Wood Frame (Class IB)

40.1

All-metal (Class II)

108.5

Steel Frame (Class III)

761.3

91.1

Concrete Frame (Class IV)

$2,175.7$

318.6

Mixed Construction (Class V)

$1,782.3$

243.0

Subtotals

$4,867.9$

661.6

Totals

$23,738.9$

$3,979.4$

1 Losses computed using vulnerability relationships developed by the Applied Technology Council (1985).

2 Losses computed using the vulnerability relationships shown in Figure 11 and Table 6. 
TABLE 13. SUMMARY OF ESTTMATED LOSSES, MODERATE PROVO SEGMENT EARTHQUARE $\left(M_{s}=6.5\right)$

Losses in the Four County Area

\begin{tabular}{|c|c|c|}
\hline ber & Value & $\begin{array}{c}\text { Losses }^{1} \\
\$ \times 10^{6}\end{array}$ \\
\hline
\end{tabular}

\section{Dwe11ings}

Wood Frame

1-4 units (Class IA) 122,695

$6,308.6$

152.7

237.7

$\geq 5$ units (Class IB) 21,824

$1,140.3$

32.4

48.5

Masonry (Classes VB \& VE)

$\begin{array}{lrrrr}1-4 \text { units } & 184,042 & 9,462.9 & 475.1 & 1,285.8 \\ \geq 5 \text { units } & 32,736 & 1,959.2 & 129.0 & 385.6 \\ \text { ubtotals } & 361,296 & 18,871.0 & 789.2 & 1,957.6\end{array}$

Non-dwe11ings

Wood Frame (Class IB)

40.1

1.8

A11-meta1 (Class II)

108.5

2.0

Steel Frame (Class III)

761.3

50.4

Concrete Frame (Class IV)

$2,175.7$

161.7

Mixed Construction (Class V)

$1,782.3$

139.6

Subtotals

4.867 .9

355.5

Totals

$23,738.9$

$2,313.1$

1 Losses computed using vulnerability relationships developed by the Applied Technology Council (1985).

2 Losses computed using the vulnerability relationships shown in Figure 11 and Table 6. 
TABLE 14. SUMMARY OF ESTIMATED LOSSES,

SMALL WEBER SEGMENT EARTHQUAKE $\left(M_{\mathbf{L}}=5.5\right)$

Losses in the Four County Area

$\begin{array}{cccc}\text { Number } & \text { Value } & \text { Losses }^{1} & \text { Losses }^{2} \\ & \$ \times 10^{6} & \$ \times 10^{6} & \$ \times 10^{6}\end{array}$

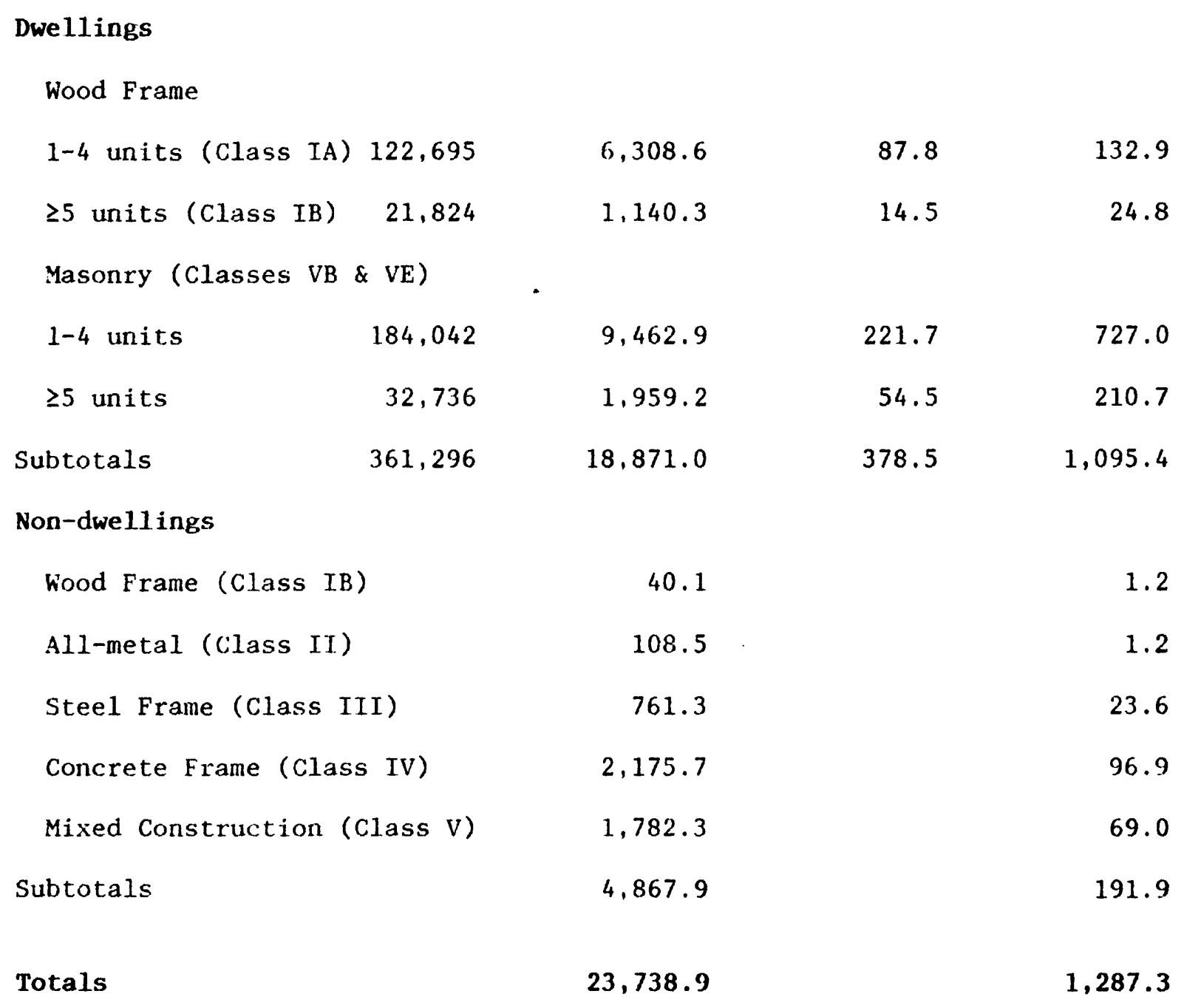

1 Losses computed using vulnerability relationships developed by the Applied Technology Council (1985).

2 Losses computed using the vulnerability relationships shown in Figure 11 and Table 6. 
TABLE 15. SUMMARY OF ESTIMATED LOSSES,

SMALL SALT LARE SEGMENT EARTHQUAKE $\left(M_{\mathrm{L}}=5.5\right)$

Losses in the Four County Area

$\begin{array}{cccc}\text { Number } & \text { Value } & \text { Losses }^{1} & \text { Losses }^{2} \\ & \$ \times 10^{6} & \$ \times 10^{6} & \$ \times 10^{6}\end{array}$

\section{Dwellings}

Wood Frame

1-4 units (C1ass IA) 122,695

$6,308.6$

136.0

206.6

$\geq 5$ units (Class IB) 21,824

$1,140.3$

26.3

39.3

Masonry (Classes VB \& VE)

$1-4$ units

184,042

$9,462.9$

387.9

$1,075.5$

$\geq 5$ units

32,736

1.959 .2

103.8

329.3

Subtotals

361,296

$18,871.0$

654.0

$1,650.7$

Non-dwellings

Wood Frame (Class IB)

40.1

1.8

Al1-metal (Class II)

108.5

2.0

Steel Frame (Class III)

761.3

45.2

Concrete Frame (Class IV)

$2,175.7$

151.6

Mixed Construction (Class V)

$1,782.3$

95.2

Subtotals

$4,867.9$

295.8

Totals

$23,738.9$

$1,946.5$

1 Losses computed using vulnerability relationships developed by the Applied Technology Council (1985).

2 Losses computed using the vulnerability relationships shown in Figure 11 and Table 6. 
TABLE 16. SUMMARY OF ESTIMATED LOSSES,

SMALL PROVO SEGMENT EARTHQUAKE $\left(M_{\mathrm{L}}=5.5\right)$

Losses in the Four County Area

Number

$$
\text { Value }
$$

$\$ \times 10^{6}$

Losses $^{1}$
$\$ \times 10^{6}$

Losses $^{2}$

$\$ \times 10^{6}$

Dwellings

Wood Frame

1-4 units (Class IA) 122,695

$6,308.6$

65.3

87.4

$\geq 5$ units (Class IB) 21,824

$1,140.3$

15.3

22.0

Masonry (Classes VB \& VE)

1-4 units

184,042

$9,462.9$

124.8

446.3

$\geq 5$ units

32,736

$1,959.2$

43.7

156.9

Subtotals

361,296

$18,871.0$

249.1

712.6

Non-dwellings

Wood Frame (Class IB)

40.1

0.8

All-metal (Class II)

108.5

0.3

Steel Frame (Class III)

761.3

17.8

Concrete Frame (Class IV)

$2,175.7$

52.9

Mixed Construction (Class V)

$1,782.3$

45.9

Subtotals

$4,867.9$

117.7

Totals

$23,738.9$

830.3

1 Losses computed using vulnerability relationships developed by the Applied Technology Council (1985).

2 Losses computed using the vulnerability relationships shown in Figure 11 and Table 6. 
TABLE 17. SUMMARY OF ESTIMATED LOSSES,

MAXIMUM SALT LARE SEGMENT EARTHQUAKE ( $\left.M_{\mathbb{8}}=7.5\right)$

Losses in Salt Lake City

Number

Value

Losses ${ }^{1}$

$\$ \times 10^{6}$

Losses $^{2}$

$\$ \times 10^{6}$

Dwellings

Wood Frame

1-4 units (Class IA) 21506

1115.7

231.0

113.5

$\geq 5$ units (Class IB)

8409

439.4

93.8

46.7

Masonry (Classes VB \& VE)

$1-4$ units

32260

1673.5

701.0

$1,048.1$

$\geq 5$ units

12614

$754 . ?$

321.4

474.2

Subtotals

74789

3983.5

$1,347.2$

$1,682.5$

Non-dwellings

Wood Frame (Class IB)

40.1

3.6

All-metal (Class II)

79.8

6.4

Steel Frame (Class III)

551.6

85.2

Concrete Frame (Class IV)

1692.4

332.6

Mixed Construction (Class V)

1013.7

179.1

Subtotals

3377.6

606.9

Totals

7361.1

$2,289.4$

1 Losses computed using vulnerability relationships developed by the Applied Technology Council (1985).

2 Losses computed using the vulnerability relationships shown in Figure 11 and Table 6. 
TABLE 18. SUMMARY OF ESTIMATED LOSSES, MAXIMUM WEBER SEGMENT EARTHQUARE $\left(M_{8}=7.5\right)$

Losses in Salt Lake City

$\begin{array}{cccc}\text { Number } & \text { Value } & \text { Losses }^{1} & \text { Losses }^{2} \\ & \$ \times 10^{6} & \$ \times 10^{6} & \$ \times 10^{6}\end{array}$

\section{Dwe11ings}

Wood Frame

1-4 units (C1ass IA) 21,506

$1,115.7$

161.0

94.7

25 units (Class IB) 8,409

439.4

63.5

37.5

Masonry (Classes VB\& VE)

$1-4$ units

32,260

$1,673.5$

549.5

$1,027.9$

25 units

12,614

754.9

249.0

466.1

Subtotals

74,789

$3,383.5$

$1,023.0$

$1,626.2$

\section{Non-dwellings}

Wood Frame (Class IB)

40.1

3.5

A11-meta1 (Class II)

79.8

6.3

Steel Frame (Class III)

551.6

80.4

Concrete Frame (Class IV)

$1,692.4$

318.2

Mixed Construction (Class V)

$1,013.7$

173.3

Subtotals

$3,37 \dot{7} .6$

581.7

Totals

$7,361.1$

$2,207.9$

1 Losses computed using vulnerability relationships developed by the Applied Technology Council (1985).

2 Losses computed using the vulnerability relationships shown in Figure 11 and Table 6. 
TABLE 19. SUMMARY OF ESTIMATED LOSSES,

MAXIMUM PROVO SEGMENT EARTHQUAKE $\left(M_{s}=7.5\right)$

Losses in Salt Lake City

$\begin{array}{cccc}\text { Number } & \text { Value } & \text { Losses }^{1} & \text { Losses }^{2} \\ & \$ \times 10^{6} & \$ \times 10^{6} & \$ \times 10^{6}\end{array}$

\section{Dwellings}

Wood Frame

1-4 units (Class IA) 21,506

$1,115.7$

75.2

80.7

$\geq 5$ units (Class IB)

8,409

439.4

30.0

32.1

Masonry (Classes VB\& VE)

1-4 units

32,260

$1,673.5$

350.8

926.4

$\geq 5$ units

12,614

754.9

160.5

421.9

Subtotals

74,789

$3,983.5$

616.5

$1,461.1$

\section{Non-dwellings}

Wood Frame (Class IB)

40.1

3.0

Al1-metal (Class II)

79.8

5.2

Steel Frame (Class III)

551.6

66.7

Concrete Frame (Class IV)

$1,692.4$

265.3

Mixed Construction (Class V)

$1,013.7$

147.2

Subtota1s

$3,377.6$

487.4

Totals

$7,361.1$

$1,948.5$

Losses computed using vulnerability relationships developed by the Applied Technology Council. (1.985).

2 Losses computed using the vulnerability relationsh shown in

Figure 11 and Table 6. 
TABLE 20. SUMMARY OF EXPECTED MAXIMUM LOSSES OVER 50 YEARS WTTH A 10\% CHANCE OF EXCEEDANCE

Losses in the Four County Area

$\begin{array}{cccc}\text { Number } & \text { Value } & \text { Losses }^{1} & \text { Losses }^{2} \\ \$ \times 10^{6} & \$ \times 10^{6} & \$ \times 10^{6}\end{array}$

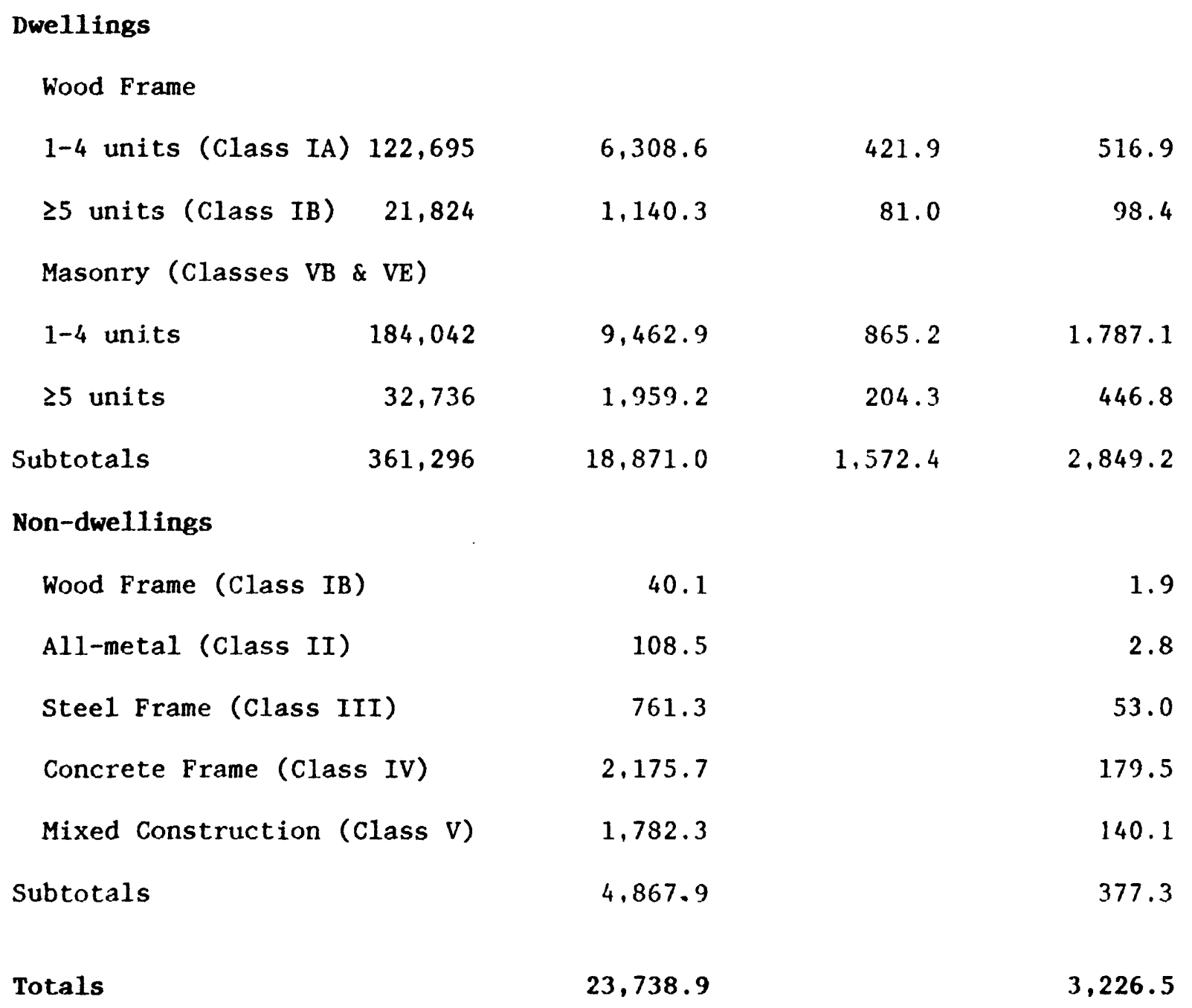

1 Losses computed using vulnerability relationships developed by the Applied Technology Council (1985).

2 Losses computed using the vulnerability relationships shown in Figure 11 and Table 6. 
2. Tables 17-19: Losses in Salt Lake City only for $M_{S}=7.5$ scenario earthquakes on the Weber, Salt Lake and Provo segments of the Wasatch fault. These losses were computed to provide additional data for earthquakes that might occur at some distance from a particular urban area and also to facilitate comparison with earlier work (Algermissen and Steinbrugge, 1984).

3. Table 20: Expected maximum losses in the four county area in 50 years with a 10 percent chance of exceedance.

\section{DISCUSSION}

Estimates of primary losses for 10 simulated earthquakes on four different faults together with a probabilistic estimate of maximum losses in 50 years have been presented for the Utah, Salt Lake, Davis and Weber County urban area. The total replacement cost or value of buildings surveyed in the four county area (1985 values) is $\$ 23.7$ billion. Losses for all earthquakes considered ranged from $\$ 830$ million $\left(M_{L}=5.5\right.$ on the provo segment) to $\$ 5.5$ billion $\left(M_{S}=7.5\right.$ on the Salt Lake Segment), a range of from 3 to $22 \%$ of the total value at risk. The expected maximum loss in a 50 year period with a $10 \%$ chance of exceedance was $\$ 3.2$ billion. One to four family dwellings constituted between 82 and $88 \%$ of the total losses for all of the earthquakes considered including the probabilistic model.

The relatively high loss estimates for the area are a result of two important factors: (1) The relatively high proportion of brick dwellings in the four county area; and (2) the high site response associated with the surface and near surface materials underlying the area.

High damage to unreinforced brick buildings is a well documented result of severe earthquakes. Recent large damaging earthquakes have established the importance of site response in earthquake damage and also that site response 
can, at least in a general way, be estimated from analysis of small earthquakes and blasts. Examples are the large site response factors that radically affected the patterns of ground shaking in the large 1985 earthquakes in Chile (Algermissen, 1985), Mexico (Stone and others, 1987; Cassero and Romero, 1986) and the small, but damaging 1986 shock in El Salvador (Ríos and others, 1986).

A source of possible uncertainty in the estimation of losses to brick buildings in the four county area is the ratio of brick to wood frame dwellings. The ratio used in this study ( $60 \%$ brick) was based on limited sampling in the study area and expert opinion from staff of the salt Lake Planning Commission. We believe that additional sampling may be warranted in future studies particularly because of the large range of site response factors that exist throughout the area.

Sensitivity studies of the effect of variability in MM intensity on the loss estimations included in Tables 21 through 23 for all of the scerario earthquakes on the salt Lake segment of the Wasatch fault. The losses for each of these scenario earthquakes have been recomputed assuming a one unit increase and decrease in the MM intensity throughout the four county area. The changes in the loss levels are striking and are a representative measure of the change in loss estimates when the MM intensity is varied over a realistic range. The sensitivity study reveals some interesting characteristics of the loss estimates. For example, for a $M_{S}=7.5$ earthquake on the Salt Lake segment (Table 21), a decrease of one intensity unit decreases losses by $20 \%$ ( $\$ 1.03$ billion) while an increase of one intensity unit reverses the losses by only $6 \%$ ( $\$ 352$ million). This variation in rate of change is associated with saturation of the vulnerability curves at high intensities. The variation in rate of change is still evident, but to a 
Table 21 -- Variation of Losses with Intensity,

for the Maximum Salt Lake Segment Earthquake $\left(M_{8}=7.5\right)$

$\begin{array}{rrrrrrrr}\text { Class } & \begin{array}{r}\text { Value } \\ \$ \times 10^{6}\end{array} & \begin{array}{r}\text { Loss }^{-1} \\ \$ \times 10^{6}\end{array} & \begin{array}{r}\text { Loss }^{\circ} \\ \$ \times 10^{6}\end{array} & \begin{array}{r}\text { Loss }^{+1} \\ \$ \times 10^{6}\end{array} & \text { \%LOS }^{-1} \text { \%Loss } & & \text { \%Loss } \\ \text { I } & 7,489.0 & 528.4 & 657.2 & 712.8 & -19.6 & 0 & +8.5 \\ \text { II } & 108.5 & 6.8 & 8.5 & 8.8 & -20.0 & 0 & +3.5 \\ \text { III } & 761.3 & 102.2 & 120.7 & 123.0 & -15.5 & 0 & +1.9 \\ \text { IV } & 2,175.7 & 352.9 & 423.8 & 438.4 & -16.7 & 0 & +3.4 \\ \text { V } & 13,204.4 & 3,454.6 & 4,267.7 & 4,546.9 & -19.1 & 0 & +6.5\end{array}$

Totals $23,738.9 \quad 4,444.9 \quad 5,477.9 \quad 5,829.9$


intensities have been reduced by one degree.

Loss $^{\circ}$ and $\%$ Loss $^{\circ}$ are the same losses and change in losses as given in Table 8 .

Loss $^{+1}$ and $\%$ Loss $^{+1}$ are the losses and change in losses when all intensities are increased by 1 degree. 
Table 22 -- Variation of Losses with Intensity,

for the Moderate Salt Lake Segment Earthquake $\left(M_{s}=6.5\right)$

$\begin{array}{rrrrrrrr}\text { Class } & \begin{array}{r}\text { Value } \\ \$ \times 10^{6}\end{array} & \begin{array}{r}\text { Loss }^{-1} \\ \$ \times 10^{6}\end{array} & \begin{array}{r}\text { Loss }^{\circ} \\ \$ \times 10^{6}\end{array} & \begin{array}{r}\text { Loss }^{+1} \\ \$ \times 10^{6}\end{array} & \text { \%Loss } & \text { \%Loss } & \text { \%Loss } \\ \text { I } & 7,489.0 & 299.1 & 474.4 & 619.3 & -37.0 & 0 & +30.5 \\ \text { II } & 108.5 & 2.4 & 5.9 & 8.2 & -59.3 & 0 & +39.0 \\ \text { III } & 761.3 & 52.9 & 91.1 & 115.6 & -41.9 & 0 & +26.9 \\ \text { IV } & 2,175.7 & 186.5 & 318.6 & 407.8 & -41.5 & 0 & +28.0 \\ \text { V } & 13,204.4 & 1,721.3 & 3,089.8 & 4,057.3 & -44.3 & 0 & +31.3\end{array}$

Totals $23,738.9 \quad 2,262.2 \quad 3,979.4 \quad 5,208.2$

Loss $^{-1}$ and $\%$ Loss $^{-1}$ are the losses and change in losses when a11 intensities have been reduced by one degree.

Loss $^{\circ}$ and $\%$ Loss ${ }^{\circ}$ are the same losses and change in losses as given in Table 12 .

Loss $^{+1}$ and $\%$ Loss $^{+1}$ are the losses and change in losses when all intensities are increased by 1 degree. 
Tab1e 23 -- Variation of Losses with Intensity, for the Small Salt Lake Segment Earthquake $\left(M_{x}=5.5\right)$

$\begin{array}{rrrrrrrr}\text { Class } & \begin{array}{r}\text { Value } \\ \$ \times 10^{6}\end{array} & \begin{array}{r}\text { Loss } \\ \$ \times 10^{6}\end{array} & \begin{array}{r}\text { Loss } \\ \$ \times 10^{6}\end{array} & \begin{array}{r}\text { Loss } \\ \$ \times 10^{6}\end{array} & \text { \%Loss }^{-1} & \text { \%Loss } & \text { \%Loss } \\ \text { I } & 7,489.0 & 105.6 & 247.7 & 423.2 & -57.3 & 0 & +71.1 \\ \text { II } & 108.5 & 0.3 & 2.0 & 5.4 & -85.0 & 0 & +170 \\ \text { III } & 761.3 & 15.6 & 45.2 & 82.7 & -65.4 & 0 & +83.0 \\ \text { IV } & 2,175.7 & 50.4 & 151.6 & 290.5 & -66.8 & 0 & +91.6 \\ \text { V } & 13,204.4 & 573.1 & 1,500.0 & 2,852.9 & -61.8 & 0 & +90.2\end{array}$

Totals $23,738.9 \quad 745.0 \quad 1,946.5 \quad 3,654.7$

Loss $^{-1}$ and $\%$ Loss $^{-1}$ are the losses and change in losses when all intensities have been reduced by one degree.

Loss $^{\circ}$ and \%Loss $^{\circ}$ are the same losses and change in losses as given in Table 15.

Loss $^{+1}$ and $\%$ Loss $^{+1}$ are the losses and change in losses when all intensities are increased by 1 degree. 
lesser extent, for the $M_{S}=6.5$ earthquake on the Salt Lake segment (Table 22). For the $M_{L}=5.5$ earthquake, the vulnerability curves are in a more linear range and the change in losses from $\Delta I=-1$ to $\Delta I=+1$ is much more 1 inear $(-62 \%$ for $\Delta I=-1$ and $+88 \%$ for $\Delta I=+1$ ) than for the larger shocks.

We also provide some information in this study on variation in loss estimates with changes in vulnerability. A measure of the sensitivity of loss estimations to changes in vulnerability assumptions is provided by the comparisons of the losses calculated for dwellings using vulnerability relationships developed by The Applied Technology Council (1985) and Steinbrugge (1986). These results are shown in Tables 7 through 20 . The differences in losses computed using the two different vulnerability curves are not very significant for wood frame dwellings, however, they are quite significant for masonry dwellings. This suggests further review and research on the vulnerability of brick dweliings is important. Loss comparisons for other than dwellings using The Applied Technology Council (1985) and the Steinbrligge (1986) vulnerability relationships were not possible because of differences in the way non-dwellings are classified in the two vulnerability studies.

Most of the area covered by this study is underlain by silt and clay having a very high site response factor, viz. 2.6 intensity units greater than rock (cf. Table 3) leading to losses which may appear very large. The effects of site response can be deducted from the data in Tables 21,22 , and 23 . Decreasing the intensities by one unit is the equivalent of decreasing the soil amplification to slightly more than that of rubble in Table 3 which in curn reduces the losses very significantly, especially at low intensities. In the case of the $M_{L}=5.5$ earthquake on the Salt Lake fault segment, the losses are reduced from $\$ 1,946.5$ million to $\$ 745$ million. This latter estimate is 
still larger than the losses sustained in the intensity VIII Whittier Narrows earthquake of October 1, 1987 of $\$ 385$ million (Hauksson and others, 1988) but this may be attributed to the comparatively high proportion of very vulnerable masonry buildings in the Salt Lake area.

Thus, these analyses provide considerable additional information about the structure of the losses and how they change.

Losses associated with liquefaction and landsliding have not been considered in this report because of uncertainty in the areal relationships for these types of geologic hazards. The losses associated with geological hazards are, however, not simply additive, the total damage to a structure being some complex combination of damage from shaking, landsliding and Ii quefaction. 


\section{REFERENCES}

Algermissen, S.T., Dewey, J.W., Langer, C.J., and Dillinger, W.H., 1974, The Managua, Nicaragua, earthquake of December 23, 1972: Location, focal mechanism, and intensity distribution: Seismological Society of America Bulletin, v. 64, p. 993-1004.

Algermissen, S.T., Steinbrugge, K.V., and Lagorio, H.L., 1978, Estimation of earthquake losses to buildings: U.S. Geological Survey open-File Report 78-441.

Algermissen, S.T., Perkins, D.M., Thenhaus, P.C., Hanson, S.L., and Bender, B.L., 1982, Frobabilistic estimates of maximum acceleration and velocity in rock in the contiguous United States: U.S. Geological Survey Open-File Report 82-1033, 99 p., 6 plates.

Algermissen, S.T., and Steinbrugge, K.V., 1984, Seismic hazard and risk assessment: Some case studies: The Geneva Papers on Risk and Insurance, Association Internationale pour l'Etude de l'Economie de l'Assurance, Geneve, v. 9, no. 30, p. 8-26.

Algermissen, S.T., Ed., 1985, Preliminary report of investigations of the Central Chile earthquake of March 3, 1985: U.S. Geological Survey OpenFile Report $85-542,180 \mathrm{p}$.

Applied Technology Council, 1985, Earthquake damage evaluation data for California: ACT-13, Redwood City, California, $492 \mathrm{pp}$. 
Borcherdt, R.D., 1970, Effects of local geology on ground motion near San Francisco Bay: Seismological Society of America Bulletin, v. 60, p. 2961.

Borcherdt, R.D., Joyner, W.B., Warrick, R.E., and Gibbs, J.F., 1975, Response of local geologic units to ground shaking, in Studies for seismic zonation of the San Francisco Bay Region: U.S. Geological Survey Professional Paper $941 \mathrm{~A}$, p. 52-67.

Cassaro, M.A., Romero, E.M., Eds., 1986, The Mexico earthquakes - i985: American Society of Civil Engineers, New York, $473 \mathrm{p}$.

Dewey, J.W. and Algermissen, S.T., 1974, Seismicity of the Middle American arch-trench system near Managua, Nicaragua: Seismological Society of America Bulletin, v. 64, p. 1033-1048.

Hauksson, E., Jones, L.M., Davis, T.L., and 13 others, 1988, The 1987 Whittier Narrows earthquake in the Los Angeles metropolitan area, California: Science, March 18, 1988.

Hays, W.W., Algermissen, S.T., Miller, R.D., and King, K.W., 1978, Preliminary ground response maps for the Salt Lake City, Utah, area: 2nd International Conference on Microzonation Proceedings, San Francisco, $1978,12 \mathrm{p}$. 
King, K.W., Hays, W.W., and McDermott, P.J., 1983, Wasatch Front Urban Area seismic response data report: U.S. Geological Survey Open-File Report 83452.

Machette, M.N., 1988, Quaternary geology along the Wasatch fault zone:

Segmentation, recent investigations, and preliminary conclusions: U.S. Geological Survey Professional Paper (this volume).

Mark, R.K., 1977, Application of linear statistical models of earthquake magnitude versus fault length in estimating maximum expectable earthquakes: Geology, v. 5, p. 464-466.

Murphy, L., 1973, San Fernando, California earthquake of February 9, 1971: U.S. Department of Commerce, Washington, D.C., v. III, 432 p.

Ríos, R., Grases, J., Ponce, L., Weidmann, N., Zegarra, L., 1986, El terremoto de San Salvador 10 de Octubre 1986: CERESIS/UNESCO, Lima, 56 p. and 3 app.

Rogers, A.M., Algermissen, S.T., Hays, W.W., and Perkins, D.M., (geological and seismological portion); Van Strein, D.O., Hughes, H.C., Hughes, R.C., Lagorio, H.J., and Steinbrugge, K.V. (engineering analysis portion), 1976, A study of earthquake losses in the Salt Lake City, Utah, area: U.S. Geological Survey open-File 76-89, $375 \mathrm{p}$. 
Rogers, A.M., Carver, D.L., Hays, W.W., King, K.W., and Miller, R.D., 1984, Preliminary estimates of geographic variation in relative ground shaking in the Wasatch front urban corridor: U.S. Geological Survey Open-File Report $84-763$, p. 547-556.

Rosenblueth, E., 1964, Probabilistic design to resist structures: Proc. ASCE, v. 90 (EMS), p. 182-219.

Steinbrugge, K.V., 1979, Estimation of loss estimation techniques to metropolitan Salt Lake City, Utah: Report to the U. S. Geological Survey .

Steinbrugge, K.V., 1986, Building inventory data and loss estimation methods for Salt Lake City-Ogden-Provo, Utah: Report to the U.S. Geological Survey, $48 \mathrm{pp}$. and 2 appendices.

Stone, W.C., Yokel, F.Y., Celebi, M., Hanks, T., Leyendecker, E.V., 1987, Engineering aspects of the September 19, 1985 Mexico earthquake: National Bureau of Standards, Washington, D.C., $215 \mathrm{p}$.

U. S. Department of Commerce, Bureau of the Census, 1983a, Census Tracts, Provo-Orem, Utah Standard Metropolitan Statistical Area: PHC80-2-294, June 1983.

U. S. Department of Commerce, Bureau of the Census, 1983b, Census Tracts, Salt Lake City-Ogden, Jtah Standard Metropolitan Statistical Area: PHC80-2317, June 1983 . 
U. S. Department of Commerce, Bureau of the Census, 1983c, Census of Population and Housing: Master Area Reference File (MARF) 2, on magnetic tape, June 1983 .

\section{ACKNOWLEDGMENTS}

The authors wish to acknowledge the help of Mr. Richard M. Lockwood of the Salt Lake Board of Realtors and Ms. Linda Pollock of the Ogden Board of Realtors, as well as Mr. Neil Olson of the Salt Lake Planning Commission. 


\section{ISOSEISMALS OF SOME HISTORICAL EARTHQUAKES AFFECTING \\ THE WASATCH FRONT AREA, UTAH}

by

Margaret G. Hopper

U.S. Geological Survey

Denver, Colorado

\section{Abstract}

Isoseismals were drawn for thirteen historical earthquakes that caused damage-level intensities (MMI $\geq V I)$ in the four Wasatch Front counties of Weber, Davis, Salt Lake, and Utah. The highest historical intensity within any of the four counties was found to be MMI VII. Davis, Salt Lake, and most of Weber counties were found to be in an area commonly reporting intensity VI. However, historic intensities in Utah county have been below the damage level except for the Provo area to the northeast of Utah Lake and the Eureka mining district (southwest corner of Utah county and adjoining Juab county). The higher intensites in the northern part of the four-county study area are the result of the 1934 Hansel Valley earthquakes and large earthquakes in southern Idaho.

\section{INTRODUCTION}

Simulations of earthquake shaking in the Wasatch Front area require a knowledge of intensities gererated by historical earthquakes affecting the area. Epicenters for all historical Utah shocks having maximum Modified Mercalli intensities $I_{o} \geq$ VI (Wood and Neumann, 1931) are shown in figure 1. For this study isoseismal maps were made showing a four-county study area (Weber, Davis, Salt Lake, and Utah Counties) (figure 2). The set of thirteen earthquakes mapped in this study (table 1) all caused damage (MMI $\geq \mathrm{VI})$ within this four-county area. Most were small local shocks $\left(I_{o}=\mathrm{VI}\right)$, but a few were larger, more distant shocks which produced MMI $\geq$ VI within the study area. For each earthquake there was available at least enough intensity information at locatable points for rough isoseismals to be contoured.

\section{ISOSEISMALS}

\section{Eureka Earthquake}

The earthquake of August 1 (figure 3) twisted the deep shaft of the Mammoth Mine so that the cage could not be lowered. At Santaquin an adobe house was split in two (Townley and Allen, 1939). 


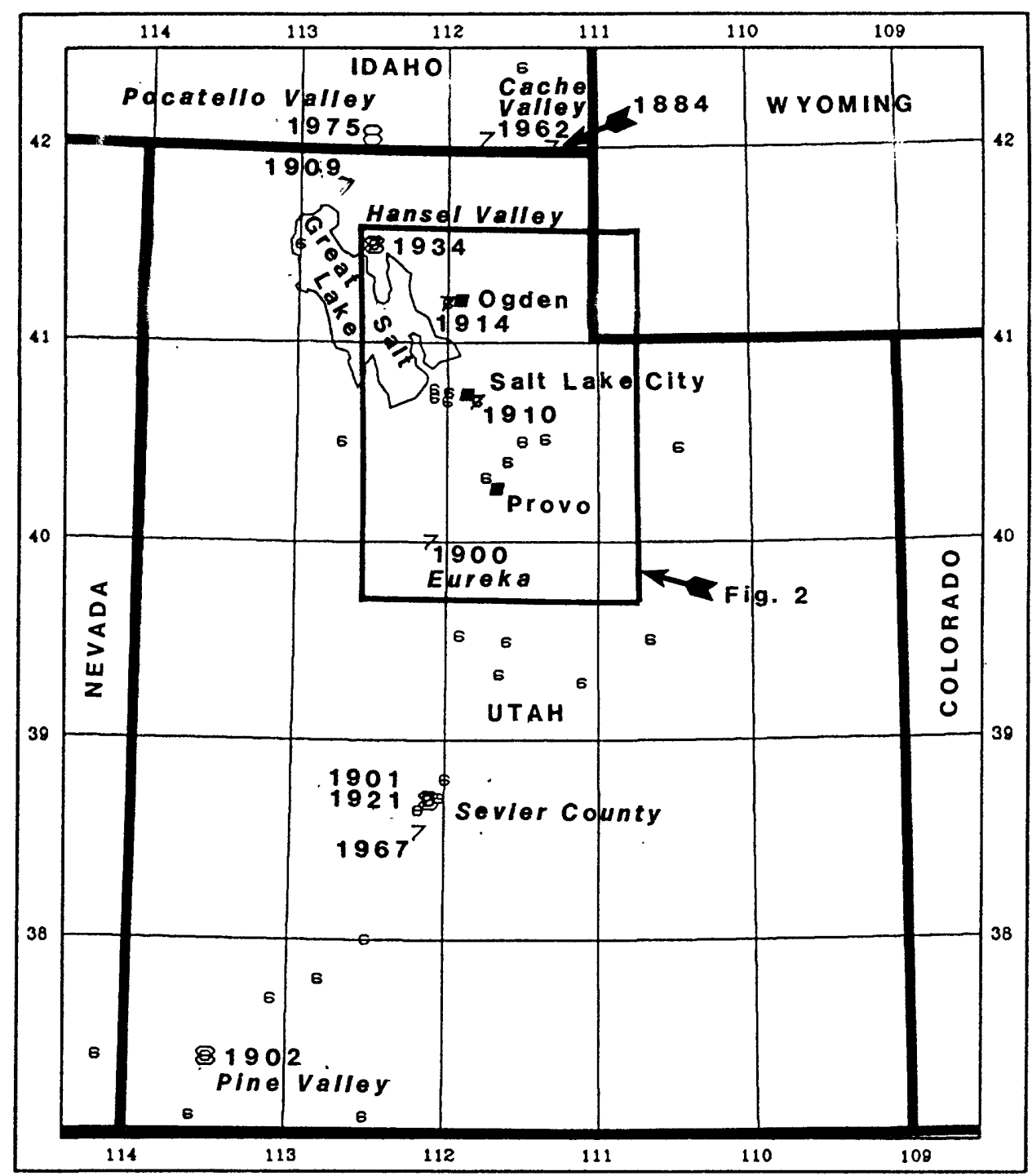

Historical Epicenters with Maximum Intensity of VI M.M. or Greater (Stover and others, 1886a, 1888b)

\begin{tabular}{llllll}
$0 \quad$ & 60 & 100 & $150 \quad 200 \quad 250$ & KTLOMETERS \\
\hline
\end{tabular}

Figure 1. Epicenters of historical Utah earthquakes having maximum Modified Mercalli intensities $I_{0} \geq V I$. Numbers are plotted at epicenters and indicate the maximum Modified Mercalli intensities. Locations and maximum MMl's are from Stover and others (1986a,b). 


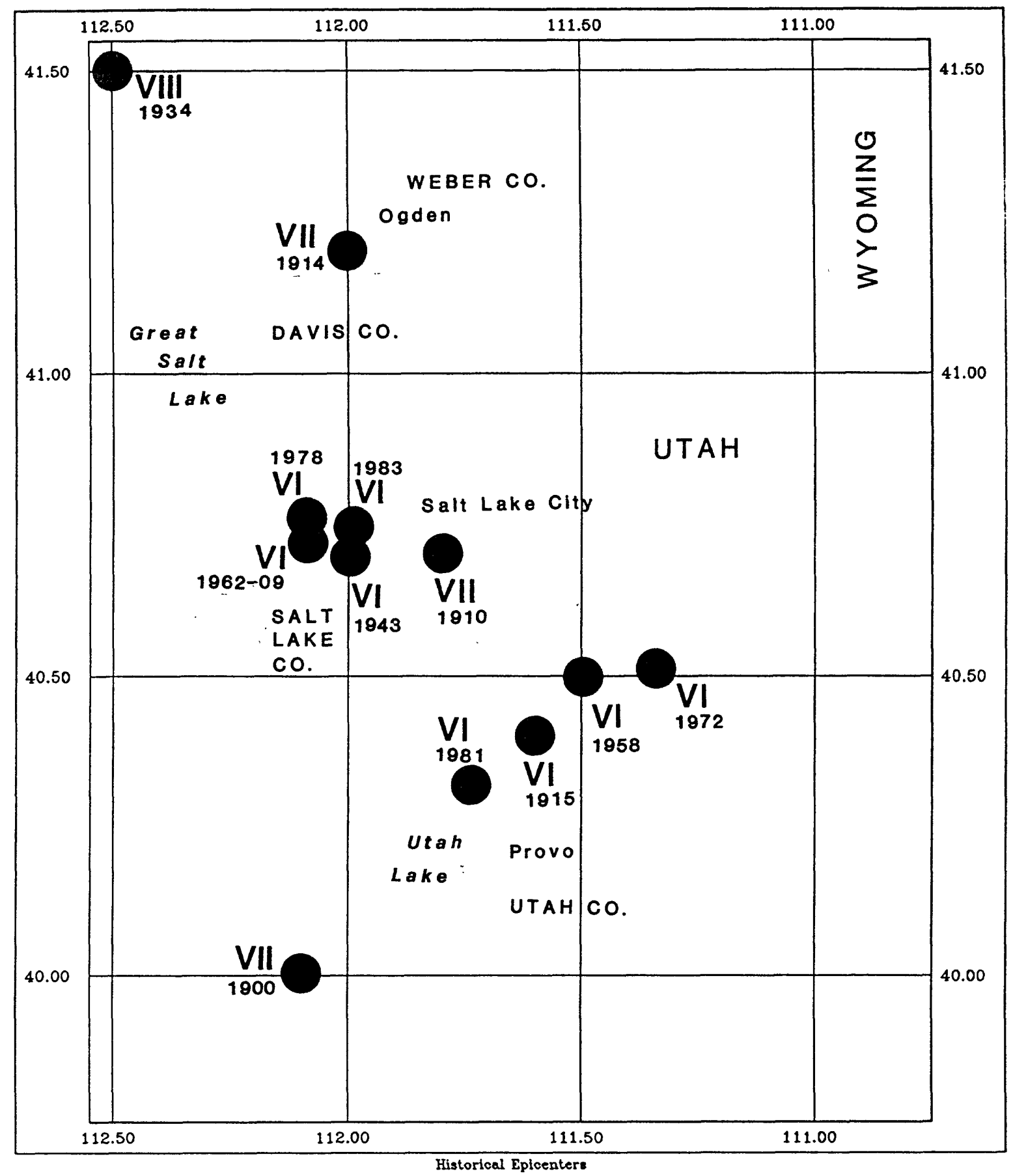

Figure 2. Epicenters of historical earthquakes used in this study. The dots show the locations of the epicenters; the roman numerals indicate their maximum Modified Mercalli intensities. Each of these earthquakes caused damaging intensities (MMI $\geq \mathrm{VI}$ ) within the four-county study area. See table 1 . 


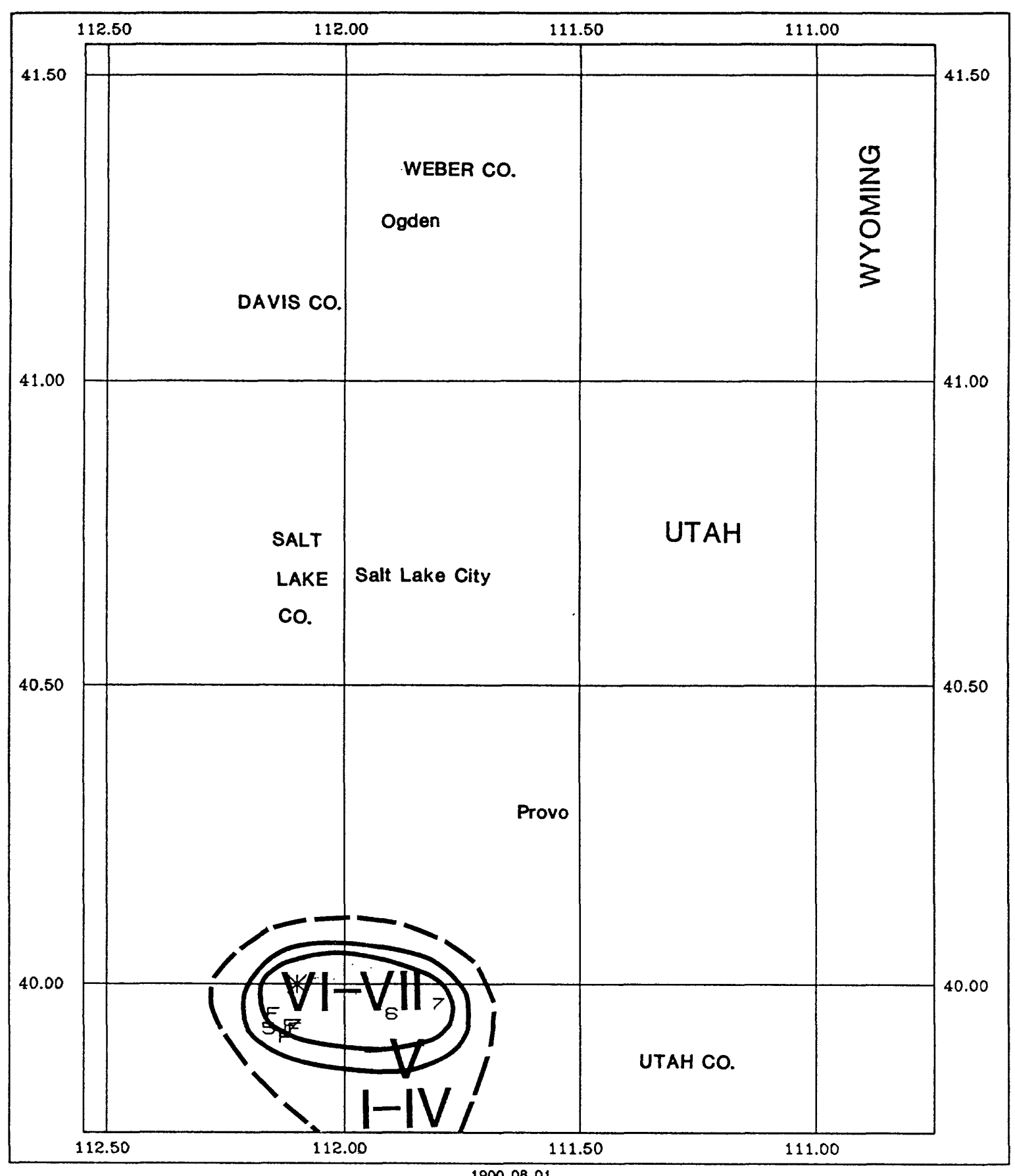

18000801

Figure 3. Isoseismal map (portion within the four-county study area) for the earthquake of August 1, 1900, Eureka, Utah. The maximum Modified Mercalli intensity is VII. The star indicates the epicenter. The numbers indicate site intensities and the roman numerals indicate isoseismal intensities (MMI). ' $F$ ' is used for a report of 'felt' that was not assigned a MMI. Isoseismals (dashed where uncertain) are by the author. 
TABLE 1. Earthquakes Used in Study 1

\begin{tabular}{|c|c|c|c|c|c|c|c|c|c|}
\hline YEAR & DATE & TIME $^{2}$ & LAT & LONG & $\mathrm{NO}^{3}$ & $\mathbf{b}$ & MAGNITUDE & AREA $^{4}$ & LOCATION \\
\hline 1900 & 0801 & $07: 45$ & 40.00 & 112.10 & 9 & VII & $5.7^{5}$ & 1.500 & Eureka \\
\hline 1910 & 0522 & $14: 28$ & 40.70 & 111.80 & 3 & VII & $5.7^{5}$ & 9,100 & Salt Lake City \\
\hline 1914 & 0513 & $17: 15$ & 41.20 & 112.00 & 3 & VII & $5.7^{5}$ & 20,700 & Ogden \\
\hline 1915 & 0715 & 22:00 & 40.40 & 111.60 & 6 & VI & $5.0^{5}$ & 12,900 & Provo \\
\hline 1934 & 0312 & 15:06 & 41.50 & 112.50 & 154 & VIII & 6.6 UK GR ${ }^{6}$ & 440,000 & Kosmo, Hansel Valley \\
\hline 1943 & 0222 & $14: 20$ & 40.70 & 112.00 & 20 & VI & $5.0^{5}$ & Local & Salt Lake City \\
\hline 1958 & 0213 & $22: 52$ & 40.50 & 111.50 & 6 & VI & $5.0^{5}$ & 3,100 & Wallsburg \\
\hline 1962 & 0830 & $13: 35$ & 42.04 & 111.74 & 240 & VII & $5.7 \mathrm{ML} \mathrm{UU^{7 }}$ & 168,000 & Cache Valley \\
\hline 1962 & 0905 & $16: 04$ & 40.72 & 112.09 & $\mathbf{5 5}$ & VI & $5.2 \mathrm{ML} \mathrm{UU}^{7}$ & 23,300 & Salt Lake City \\
\hline 1972 & 1001 & $19: 42$ & 40.51 & 111.35 & 23 & VI & $4.3 \mathrm{ML} \mathrm{U^{7 }}$ & 6,500 & Midway \\
\hline 1978 & 0309 & $06: 31$ & 40.76 & 112.09 & 19 & VI & $3.2 \mathrm{ML} \mathrm{UU} \mathrm{UU}^{7}$ & None & Magna \\
\hline 1981 & 0220 & $09: 13$ & 40.32 & 111.74 & 9 & VI & $3.9 \mathrm{ML} \mathrm{UU}{ }^{7}$ & None & Orem \\
\hline $1983^{8}$ & 1008 & $11: 58$ & 40.75 & 111.99 & 25 & VI & $4.3 \mathrm{ML} \mathrm{UU^{7 }}$ & None & West Valley City \\
\hline
\end{tabular}

1 All information in this table is from Stover and others (1986a) except as noted.

2 UTC

3 Number of located sites with assigned Modified Mercalli intensities

4 Felt areas in $\mathbf{k m}^{2}$ (Coffman and others, 1982)

5 Magnitude estimated from the maximum MMI, $I_{\mathrm{o}}$ (Arabasz and McKee, 1979)

6 Gutenberg-Richter magnitude

7 University of Utah magnitude

${ }^{8}$ Information on this earthquake from Stover (1987)

\section{Salt Lake City Earthquake}

The earthquake of May 22 (figure 4) on the Wasatch fault damaged several buildings in Salt Lake City, shaking plaster from ceilings and toppling chimneys on poorly constructed buildings, but leaving well-constructed buildings unharmed. The earthquake did minor damage at Bingham and Garfield, but was not felt beyond 50 miles $(80 \mathrm{~km})$ from Salt Lake City. It was followed by two lighter shocks. (Williams and Tapper, 1953)

\section{Ogden Earthquake}

The earthquake of May 13 (figure 5) on the Wasatch fault cracked walls, toppled a few chimneys, and broke plate glass windows in Ogden. In Salt Lake City dishes were broken. The shock was followed by a second, lighter shock. (Williams and Tapper, 1953) 


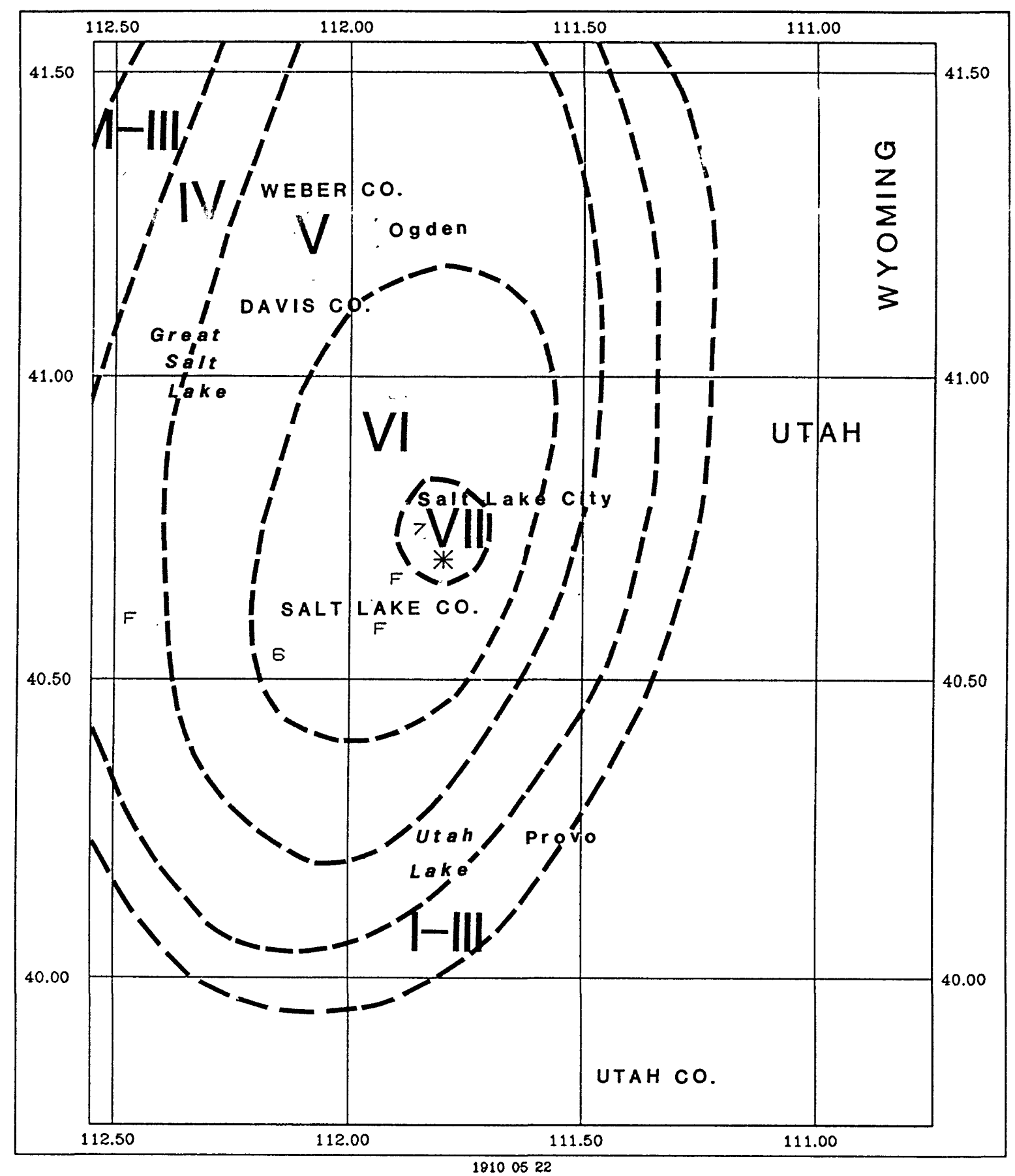

Figure 4. Isoseismal map (portion within the four-county study area) for the earthquake of May 22, 1910. Salt Lake City, Utah. The maximum Modified Mercalli intensity is VII. The star indicates the epicenter. The numbers indicate site intensities and the roman numerals indicate isoseismal intensities (MMI). ' $F$ ' is used for a report of 'felt' that was not assigned a MMI. Isoseismals (dashed where uncertain) are by the author. 


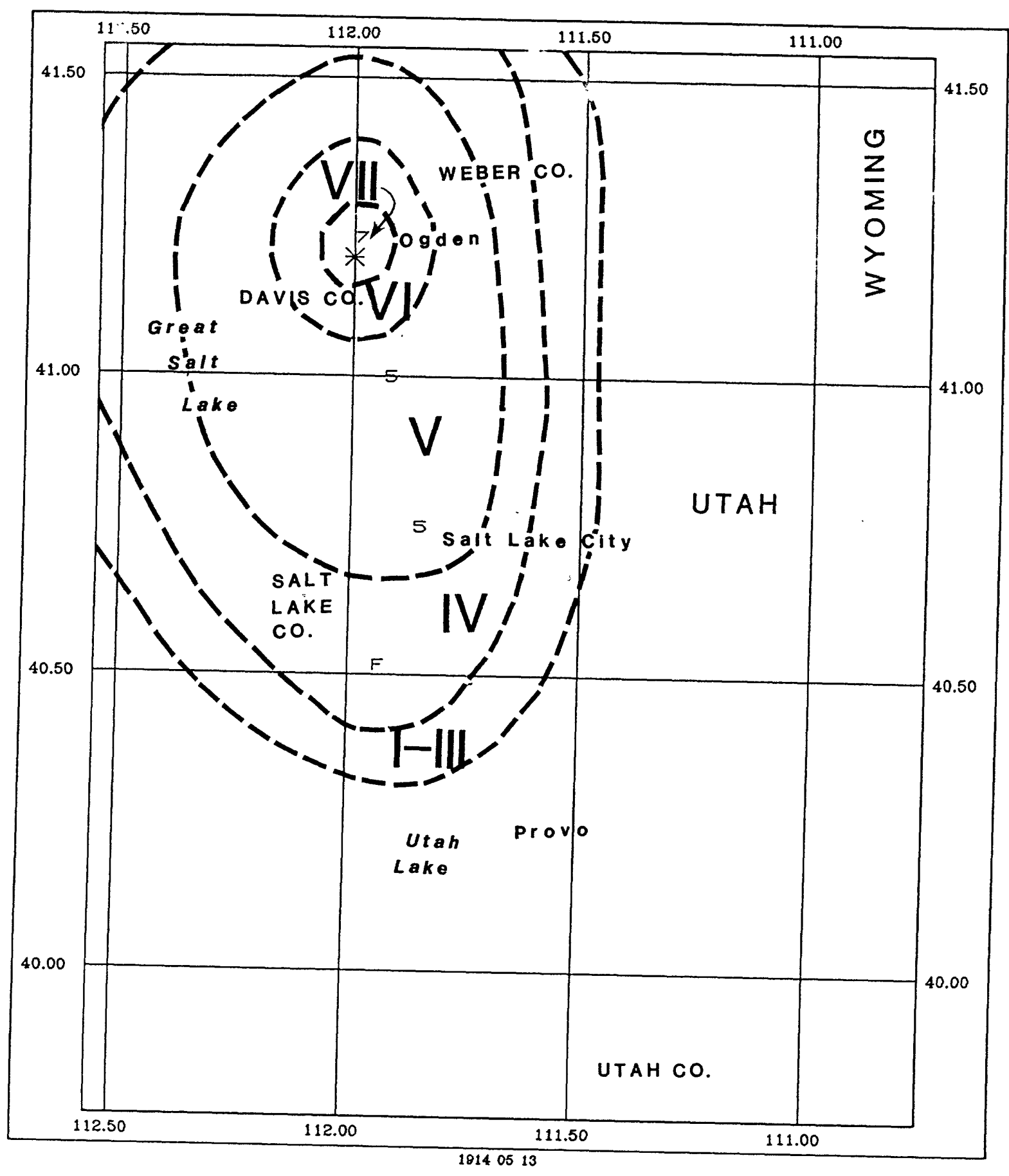

Figure 5. Isoseismal map (portion within the four-county study area) for the earthquake of May 13, 1914, Ogden, Utah. The maximum Modified Mercalli intensity is VII. The star indicates the epicenter. The numbers indicate site intensities and the roman numerals indicate isoseismal intensities (MMI). ' $F$ ' is used for a report of 'felt' that was not assigned a MMI. Isoseismals (dashed where uncertain) are by the author. 


\section{Provo Earthquake}

The earthquake of July 15 (figure 6) on the Wasatch fault cracked ceilings at Provo. (Williams and Tapper, 1953)

\section{Hansel Valley Earthquake}

The earthquake of March 12 (figures 7 and 8) occurred in a sparcely populated area and did very little damage except for fissures, ground cracks and liquefaction. At Kosmo a poorly constructed brick building was severely cracked, and at Monument all the chimneys were thrown down.

Beyond the immediate meizoseismal area, chimneys fell at Bacchus, Blue Creek, Hooper, Kelton, Locomotive Springs, Promontory, and Snowville. (Neumann, 1936)

\section{Salt Lake City Earthquake}

The earthquake of February 22 (figure 9) was felt most strongly in the Salt Lake Valley west of Salt Lake City. It shook down much plaster from the new brick Bingham High School, cracked plaster, windows, and chimneys at Magna, and cracked plaster and windows in Salt Lake City (Bodle, 1945). It is presumed to be located at depth on a branch of the Wasatch fault. (Williams and Tapper, 1953).

\section{Wallsburg Earthquake}

The earthquake of February 13 (figure 10) caused minor damage at Wallsburg and Provo, where a wall was cracked and plaster fell (Brazee and Cloud, 1960).

\section{Cache Valley Earthquake}

The earthquake of August 30 (figures 11 and 12) on the East Cache Valley fault caused the most severe damage at Richmond where numerous houses lost walls, a large church was damaged beyond repair, and $75 \%$ or the older chimneys fell. 


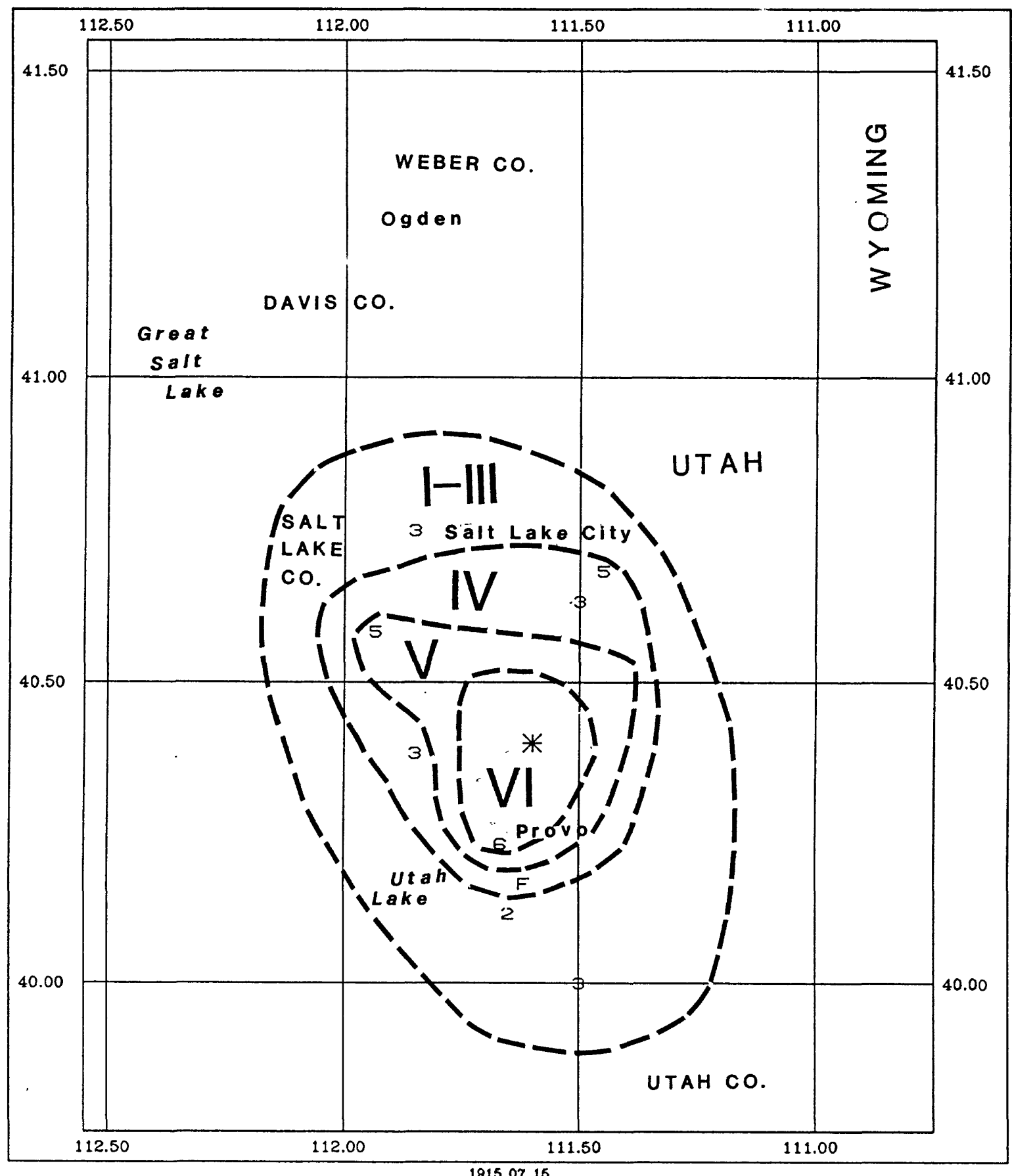

Figure 6. Isoseismal map for the earthquake of July 15, 1915. The maximum Modified Mercalli intensity is VI. The star indicates the epicenter. The numbers indicate site intensities and the roman numerals indicate isoseismal intensities (MMI). 'F' is used for a report of 'felt' that was not assigned a MMI. Isoseismals (dashed where uncertain) are by the author. 


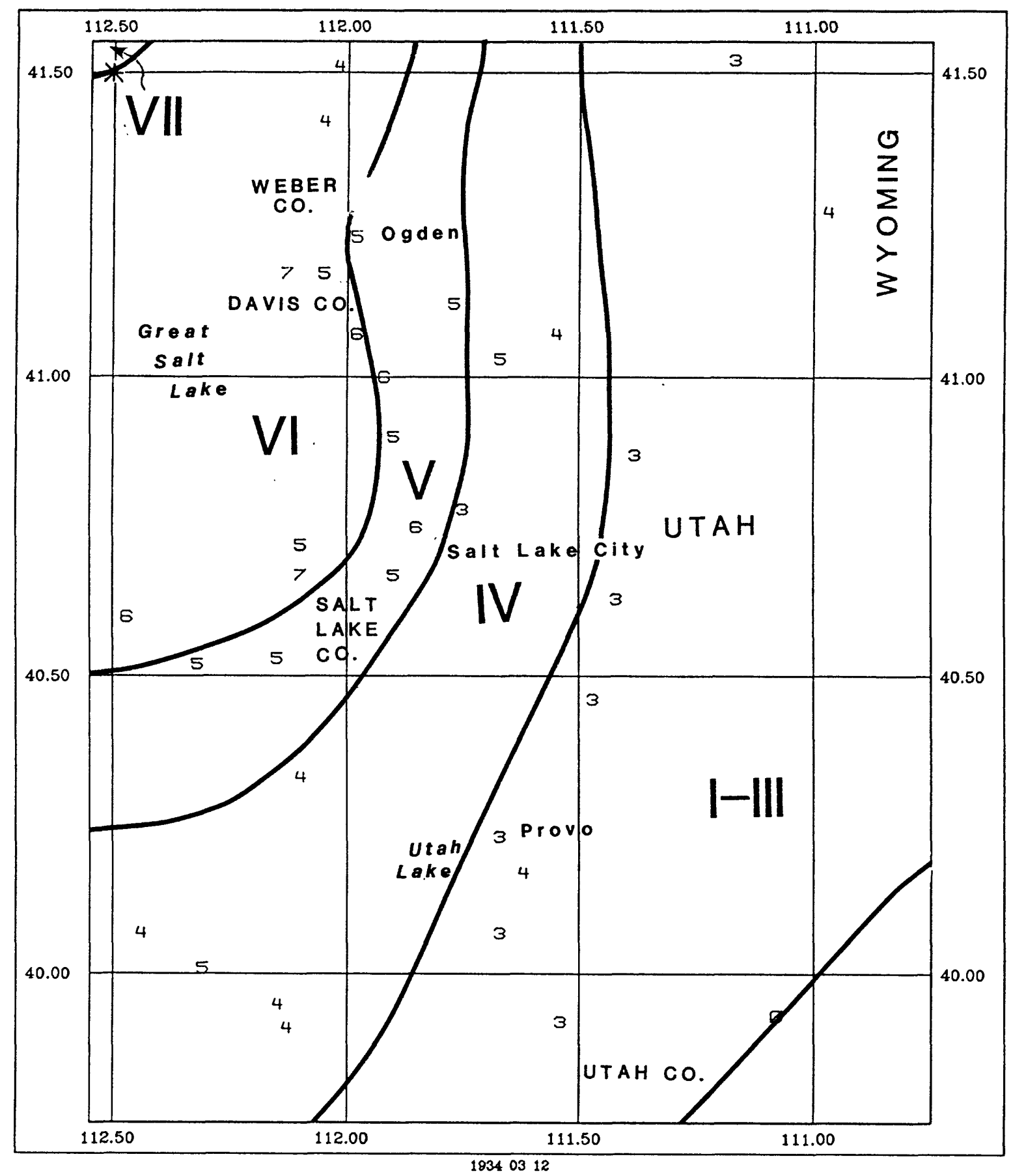

Figure 7. Isoseismal map (portion within the four-county study area) for the earthquake of March 12, 1934, Hansel Valley, Utah (Kosmo, Utah). The maximum Modified Mercalli intensity is VIII; $M_{L}$ is 6.6. The star indicates the epicenter. The numbers indicate site intensities and the roman numerals indicate isoseismal intensities (MMI). Isoseismals are from Neumann (1936). The entire isoseismal map is shown in figure 8. 


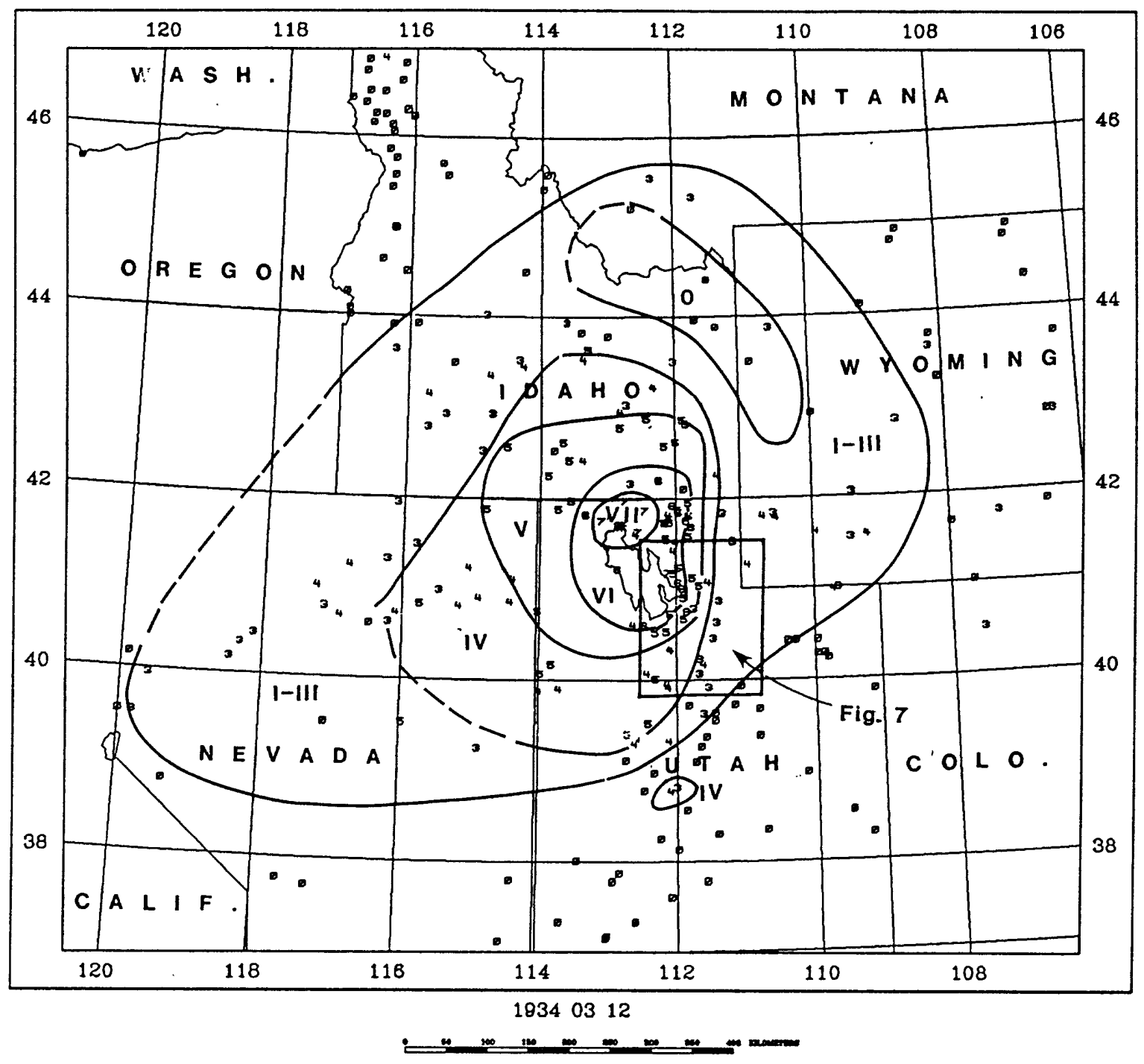

Figure 8. Isoseismal map for the earthquake of March 12, 1934. Hansel Valley, Utah (Kosmo, Utah). Maximum Modified Mercalli intensity is VIII; $M_{L}$ is 6.6. The numbers indicate site intensities and the roman numerals indicate isoseismal intensities (MMI). The inset map shows the area of figure 7 . Isoseismals are from Neumann (1936). 


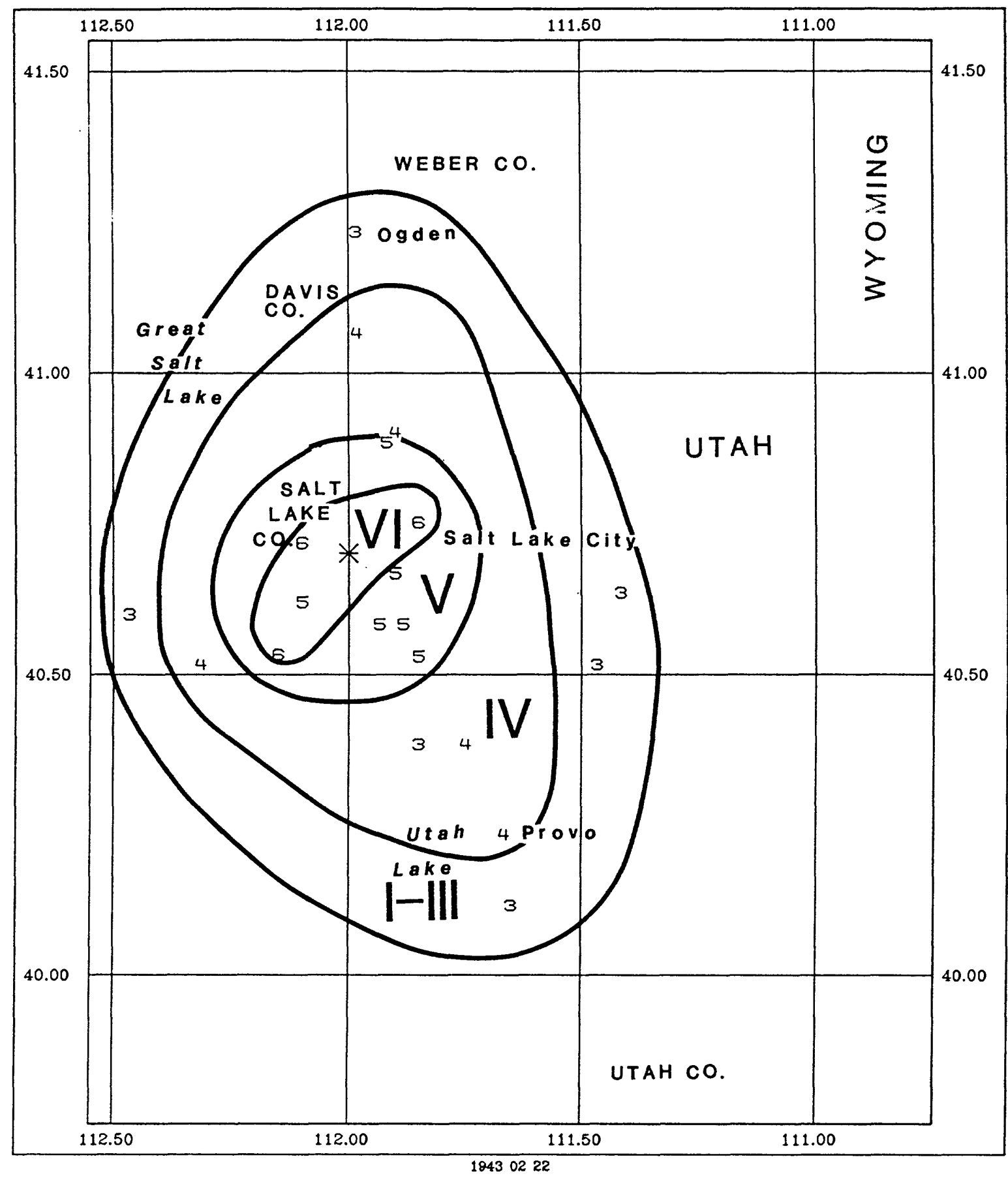

Figure 9. Isoseismal map for the earthquake of February 22, 1943. Salt Lake City, Utah. The maximum Modified Mercalli intensity is VI. The star indicates the epicenter. The numbers indicate site intensities and the roman numerals indicate isoseismal intensities (MMI). Isoseismals are by the author. 


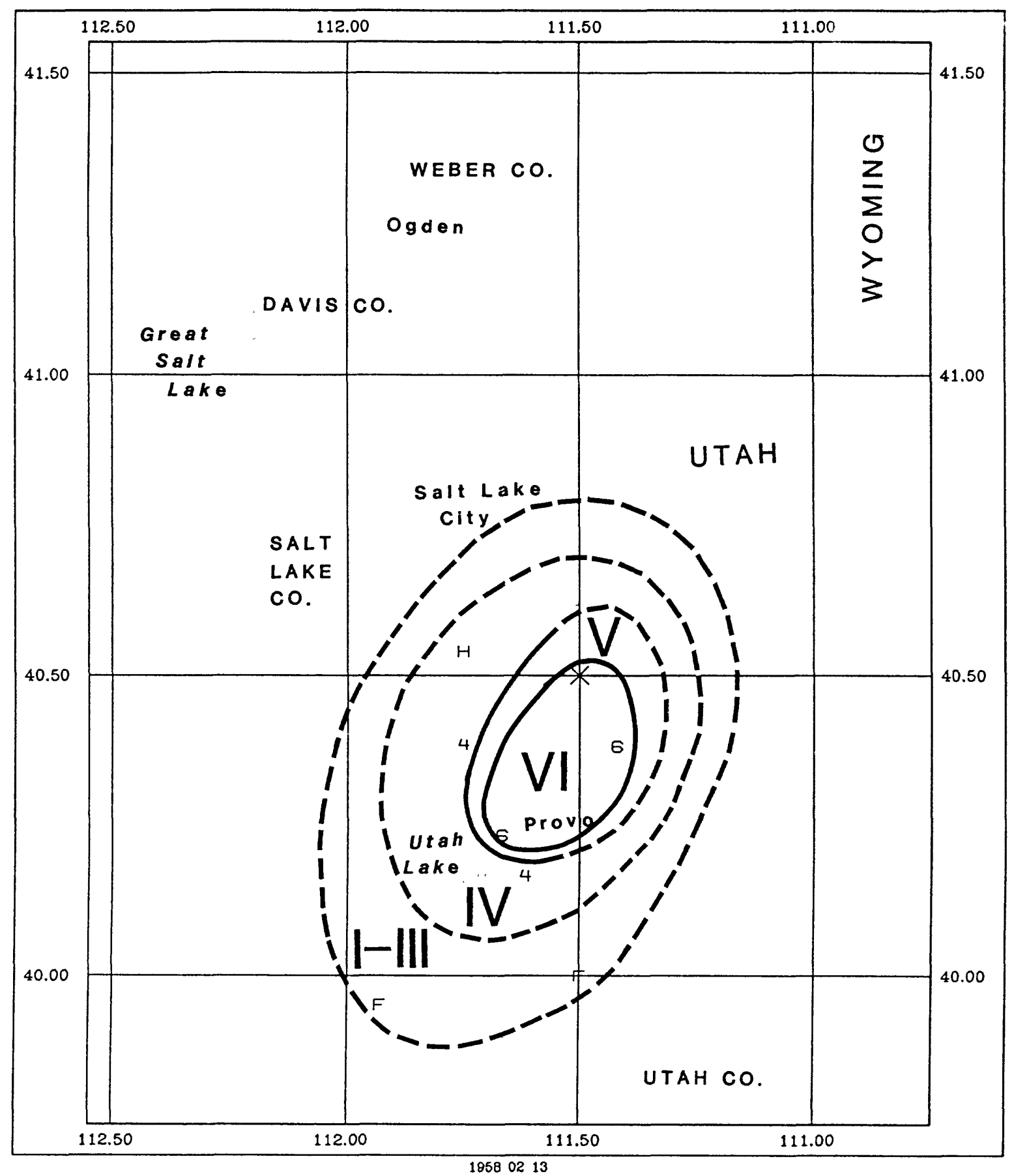

Figure 10. Isoseismal map for the earthquake of February 13, 1958, Wallsburg. Utah. The maximum Modified Mercalli intensity is VI. The star indicates the epicenter. The numbers indicate site intensities and the roman numerals indicate isoseismal intensities (MMI). ' $\mathrm{F}$ ' and ' $\mathrm{H}$ ' are used for reports of 'felt' and 'heavy' that were not assigned MMI's. Isoseismals (dashed where uncertain) are by the author. Berg and Resler (1958) developed a similar isoseismal map. 


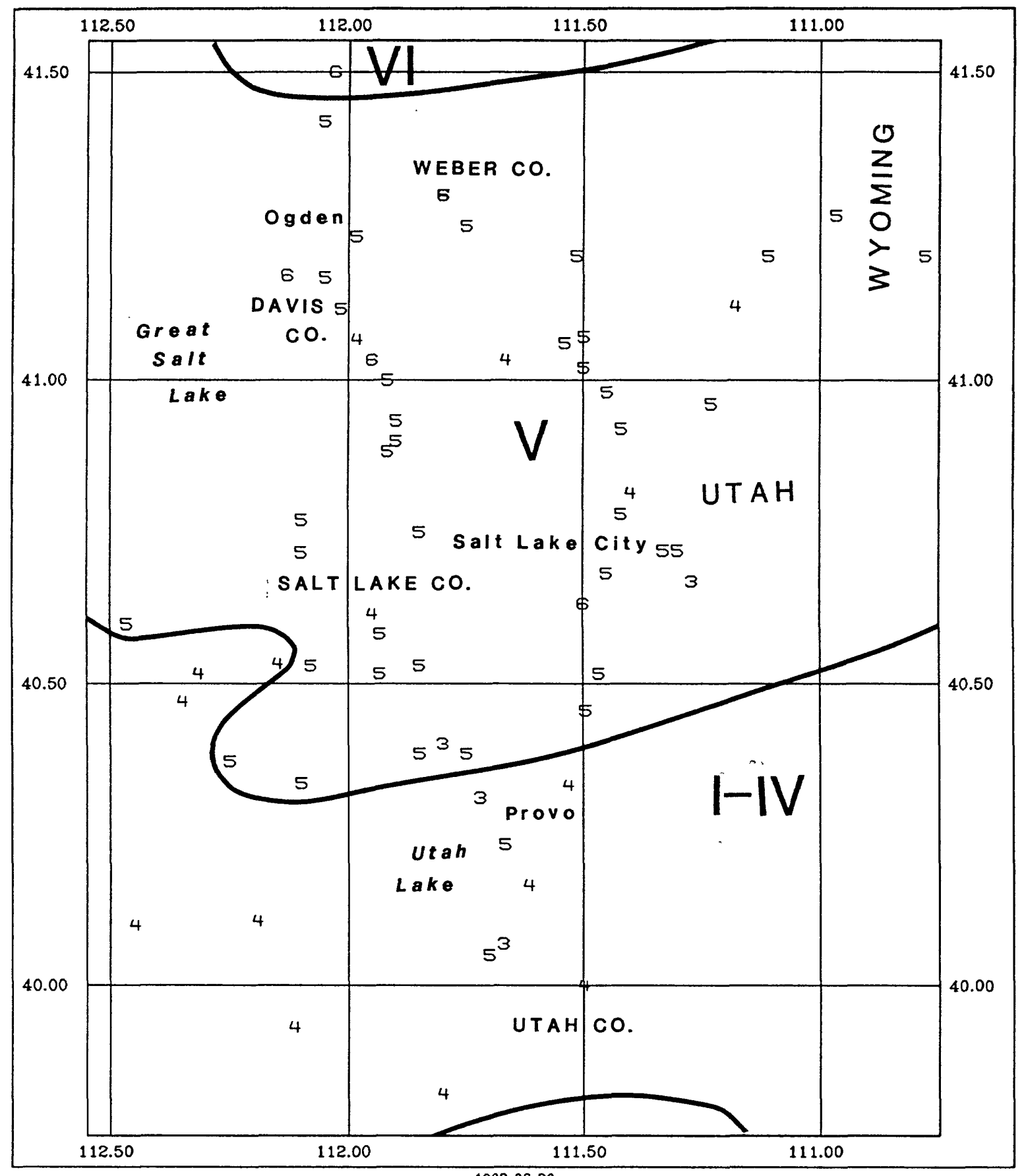

Figure 11. Isoseismal map (portion within the four-county study area)) for the earthquake of August 30, 1962, Cache Valley, Utah. The maximum Modified Mercalli intensity is VII; $M_{L}$ is 5.7. The epicenter is off the map to the north. The numbers indicate site intensities and the roman numerals indicate isoseismal intensities (MMI). Isoseismals are from Lander and Cloud (1964). The entire isoseismal map is shown in figure 12. 


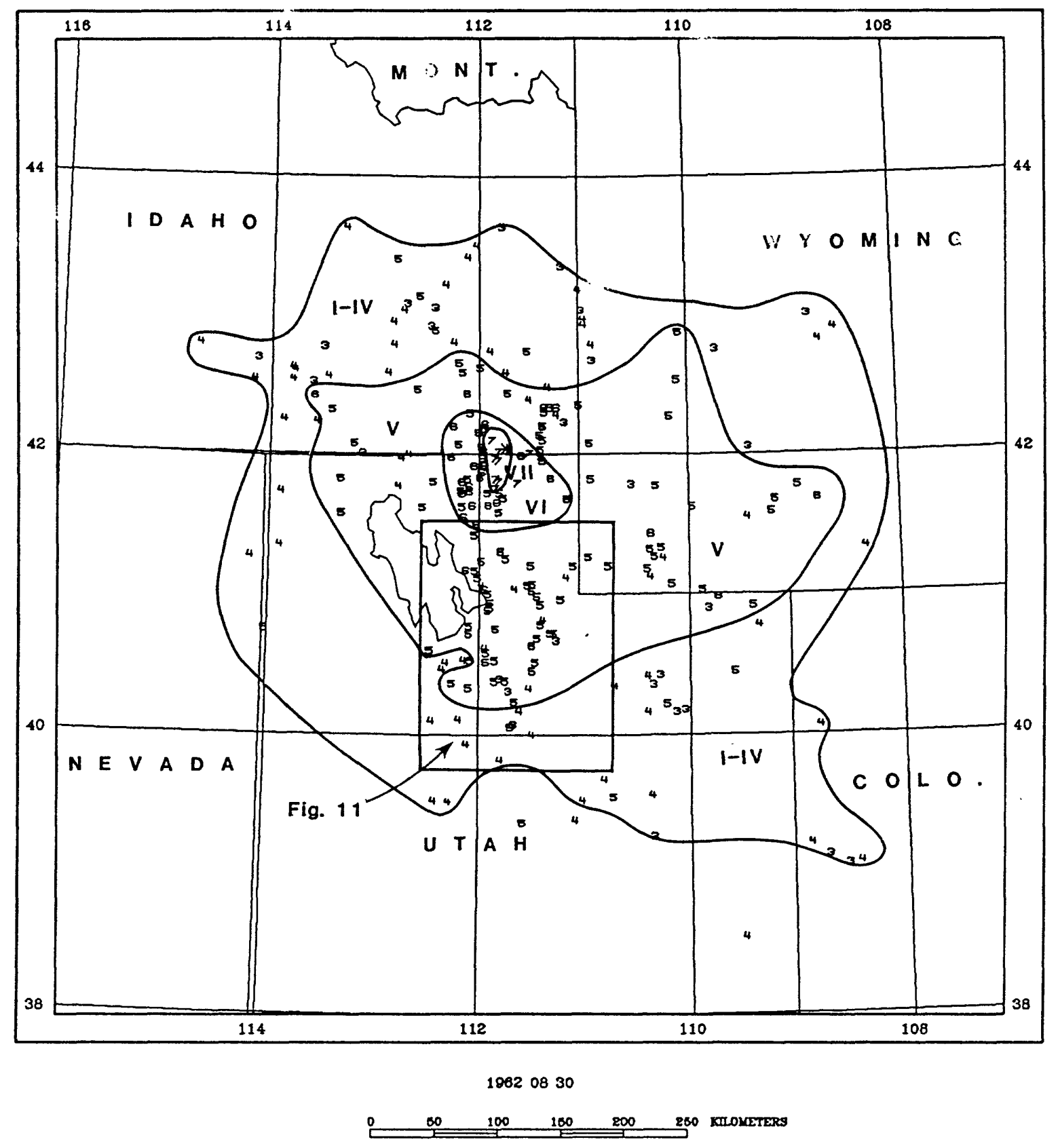

Figure 12. Isoseismal map for the earthquake of August 30, 1962, Cache Valley, Utah. The maximum Modified Mercalli intensity is VII; $M_{L}$ is 5.7. The star indicates the epicenter. The numbers indicate site intensities and the roman numerals indicate isoseismal intensities (MMI). The inset map shows the area of figure 11. Isoseismals are from Lander and Cloud (1964). 
Buildings in downtown Logan had severe damage from cracked and distorted walls, and parapets fell at the junior high school.

At Lewiston there was much chimney damage and a large parapet and the secondstory part of a brick wall fell.

At Hyde Park there was considerable chimney damage but no damage to newer brick structures.

At Smithfield plaster, walls, and chimneys cracked and bricks fell from most old chimneys.

At Franklin (Idaho) plaster, walls, and chimneys cracked, chimneys twisted and fell, and some foundations cracked.

At Preston (Idaho) a few chimneys fell and a few homes had cracked walls and fireplaces. (Lander and Cloud, 1964)

\section{Salt Lake City Earthquake}

The earthquake of September 5 (figure 13) damaged three older houses in Salt Lake City; in one the outside front wall cracked and fell through the ceiling; portions of inside walls and ceiling plaster fell in the other two. There were slight interior cracks in some large buildings in Salt Lake City and cracks and loosened acoustical tile in some of the schools. An old parapet facade pulled two inches $(5 \mathrm{~cm})$ away from one school building and the parapet had to be removed. At the newspaper office 16 windows were cracked, a light fixture fell, and there were many small cracks in walls and ceilings.

In North Salt Lake plaster, windows, walls, and chimneys were cracked.

At the Bingham Canyon mine there were slight cracks in freshly painted concreteblock walls.

At Draper plaster, walls, and cement were cracked.

At Lark walls cracked.

At Magna plaster, windows, walls, and chimneys cracked.

At Midvale plaster cracked.

At Morgan there were slight wall and foundation cracks.

At Murray plaster cracked. 


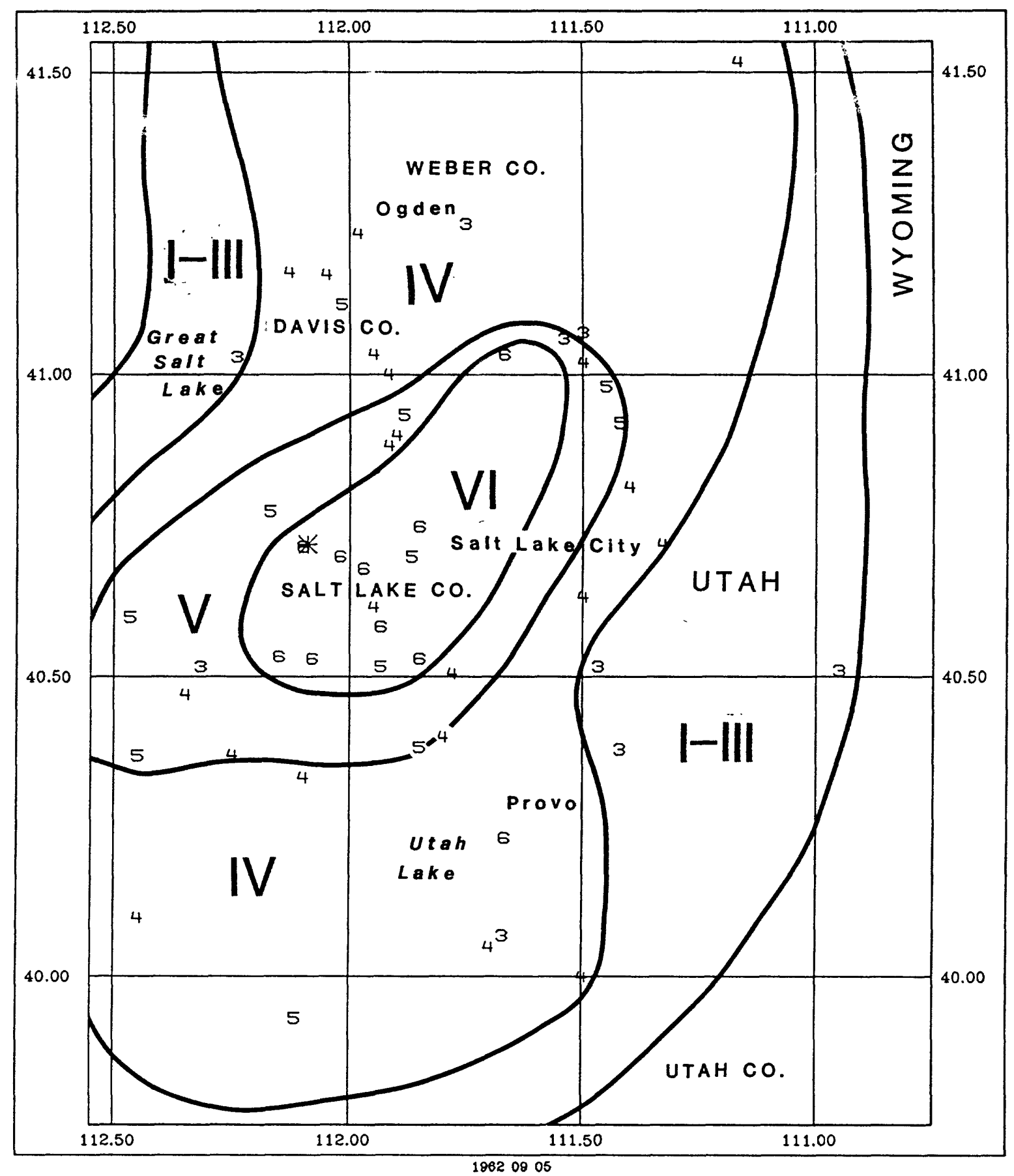

Figure 13. Isoseismal map (portion within the four-county study area) for the earthquake of September 5, 1962, Salt Lake City, Utah. The maximum Modified Mercalli intensity is VI; $M_{L}$ is 5.2. The star indicates the epicenter. The numbers indicate site intensities and the roman numerals indicate isoseismal intensities (MMI). Isoseismals are by the author. 
At Provo bricks fell from chimneys and there were a few small cracks. (Lander and Cloud, 1964)

\section{Midway Earthquake}

The earthquake of October 1 (figure 14) shook down some bricks from chimneys and cracked plaster at two schools and other places in Midway (Coffman and von Hake, 1974).

\section{Magna Earthquake}

The earthquake of March 9 (figure 15) caused damage only at Magna, where there were broken windows in several houses, cracked plaster, and cracks in the exterior walls of a fire station. (Cook, 1979; Stover and von Hake, 1980)

\section{Orem Earthquake}

The earthquake of February 20 (figure 16) cracked a foundation and caused hairline cracks in plaster and dry wall in Orem (Stover, 1984).

\section{West Valley City Earthquake}

The earthquake of October 8 (figure 17) caused damage only in West Valley City and Granger, which are western suburbs of Salt Lake City. In West Valley City chimneys cracked and one chimney fell. In Granger bricks fell from a chimney (Stover, 1987).

\section{MAXIMUM HISTORICAL INTENSITY MAP}

A map (figure 18) was made of the highest intensities experienced within the 4-county study area. This map is derived from the isoseismals and site intensities of the thirteen earthquakes listed in table 1 . It shows the maximum intensity experienced at any point due to any one of the thirteen shocks. 


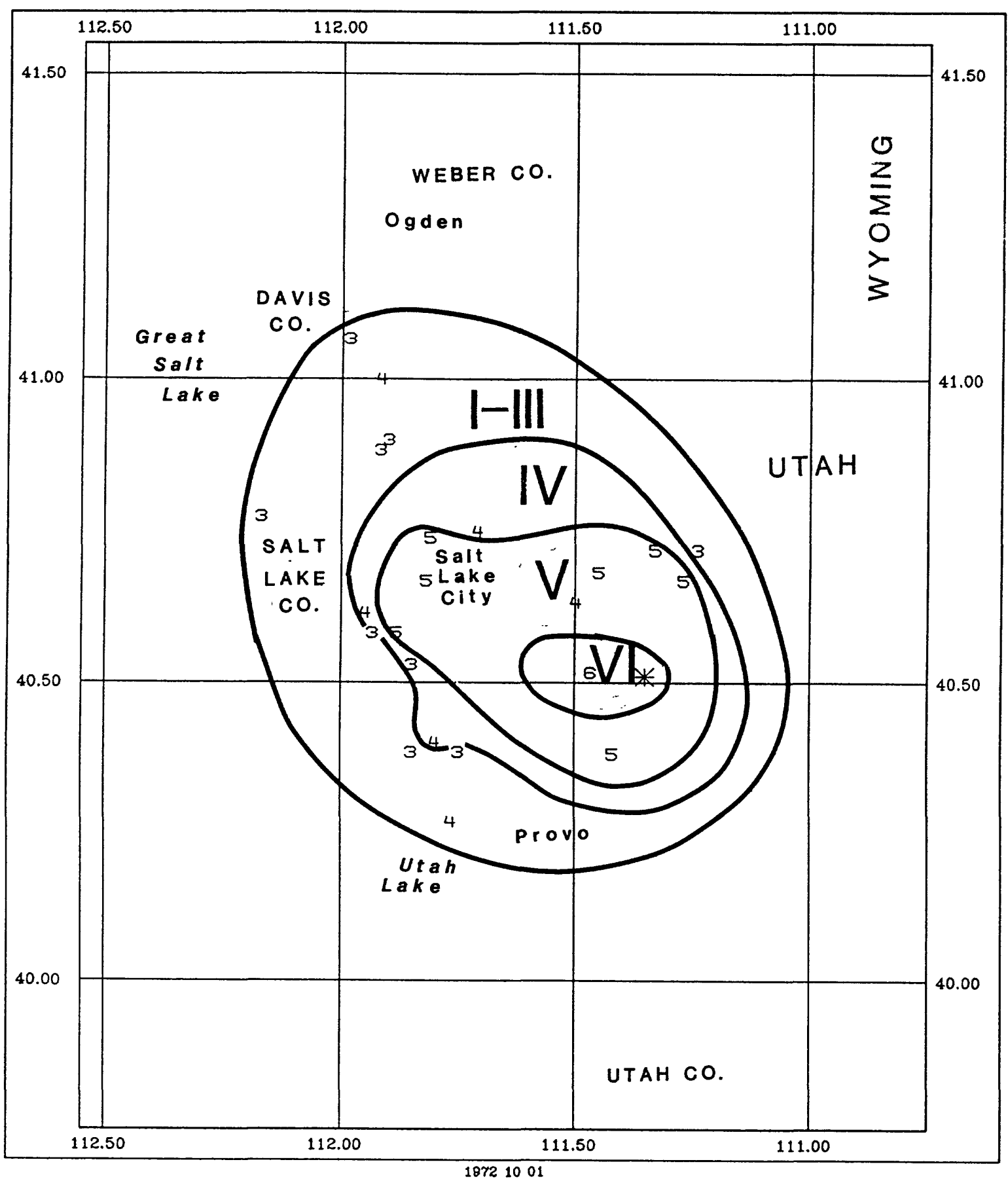

Figure 14. Isoseismal map for the earthquake of October 1. 1972, Midway, Utah. The maximum Modified Mercalli intensity is Vl; $M_{L}$ is 4.3 . The star indicates the epicenter. The numbers indicate site intensities and the roman numerals indicate isoseismal intensities (MMI). Isoseismals are by the author. 


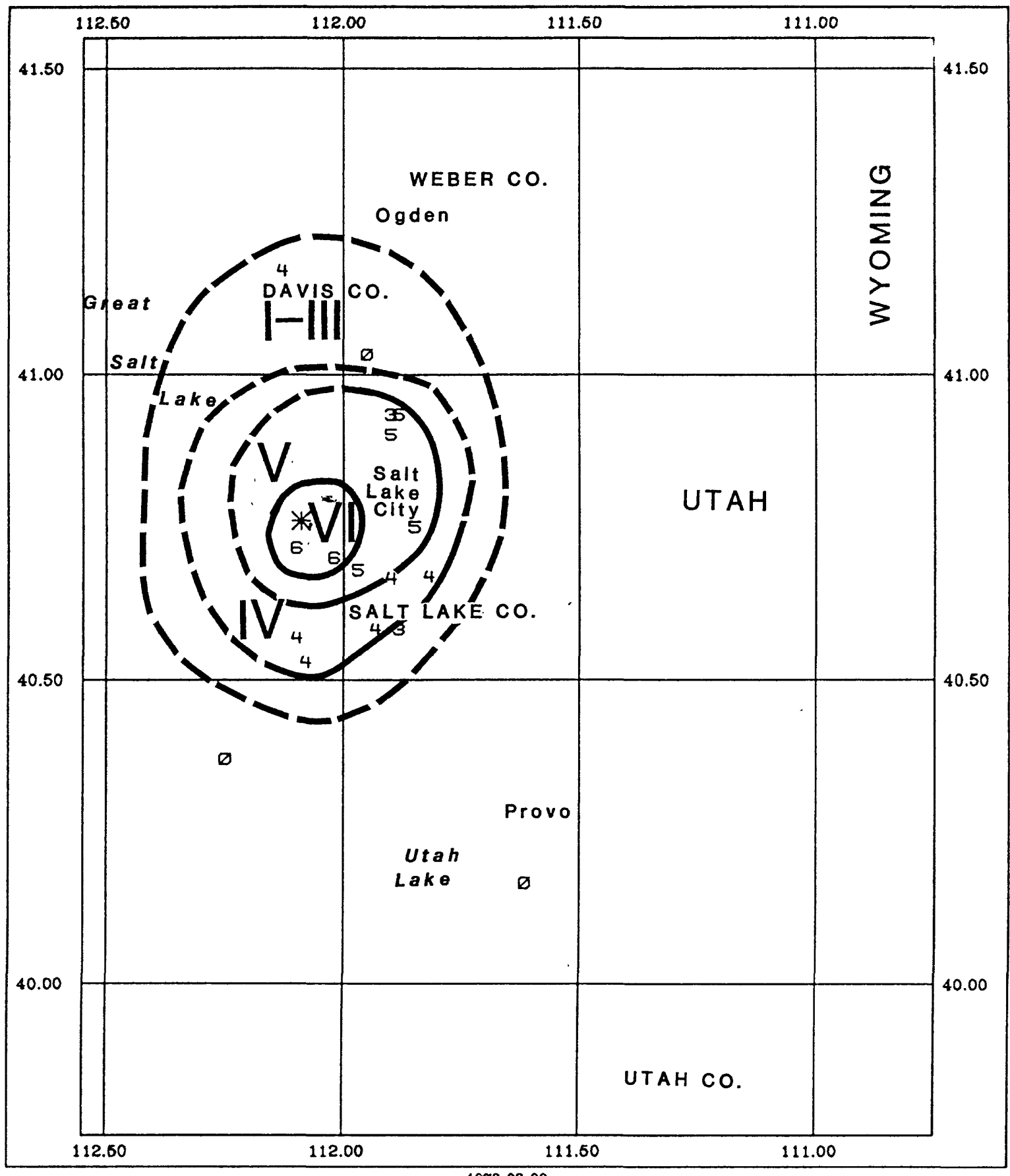

Figure 15. Isoseismal map for the earthquake of March 9. 1978, Magna, Utah. The maximum Modified Mercalli intensity is VI; $M_{L}$ is 3.2. The star indicates the epicenter. The numbers indicate site intensities and the roman numerals indicate isoseismal intensities (MMI). Isoseismals (dashed where uncertain) are by the author. 


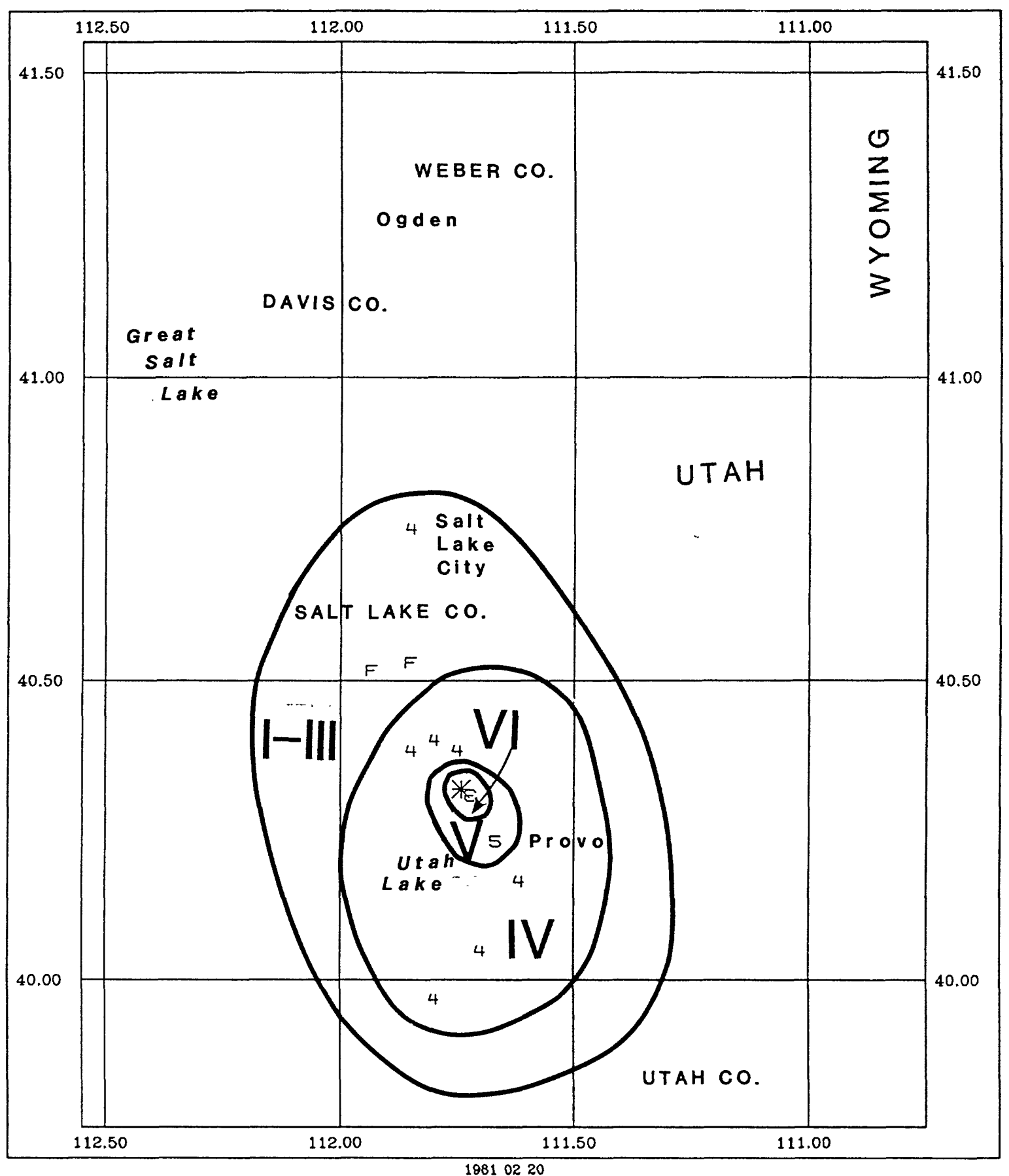

Figure 16. Isoseismal map for the earthquake of February 20, 1981, Orem, Utah. The maximum Modified Mercalli intensity is $\mathrm{Vl} ; \mathrm{M}_{\mathrm{L}}$ is 3.9. The star indicates the epicenter. The numbers indicate site intensities and the roman numerals indicate isoseismal intensities (MMI). ' $F$ ' is used for a report of 'felt' that was not assigned a MMI. Isoseismals are by the author. 


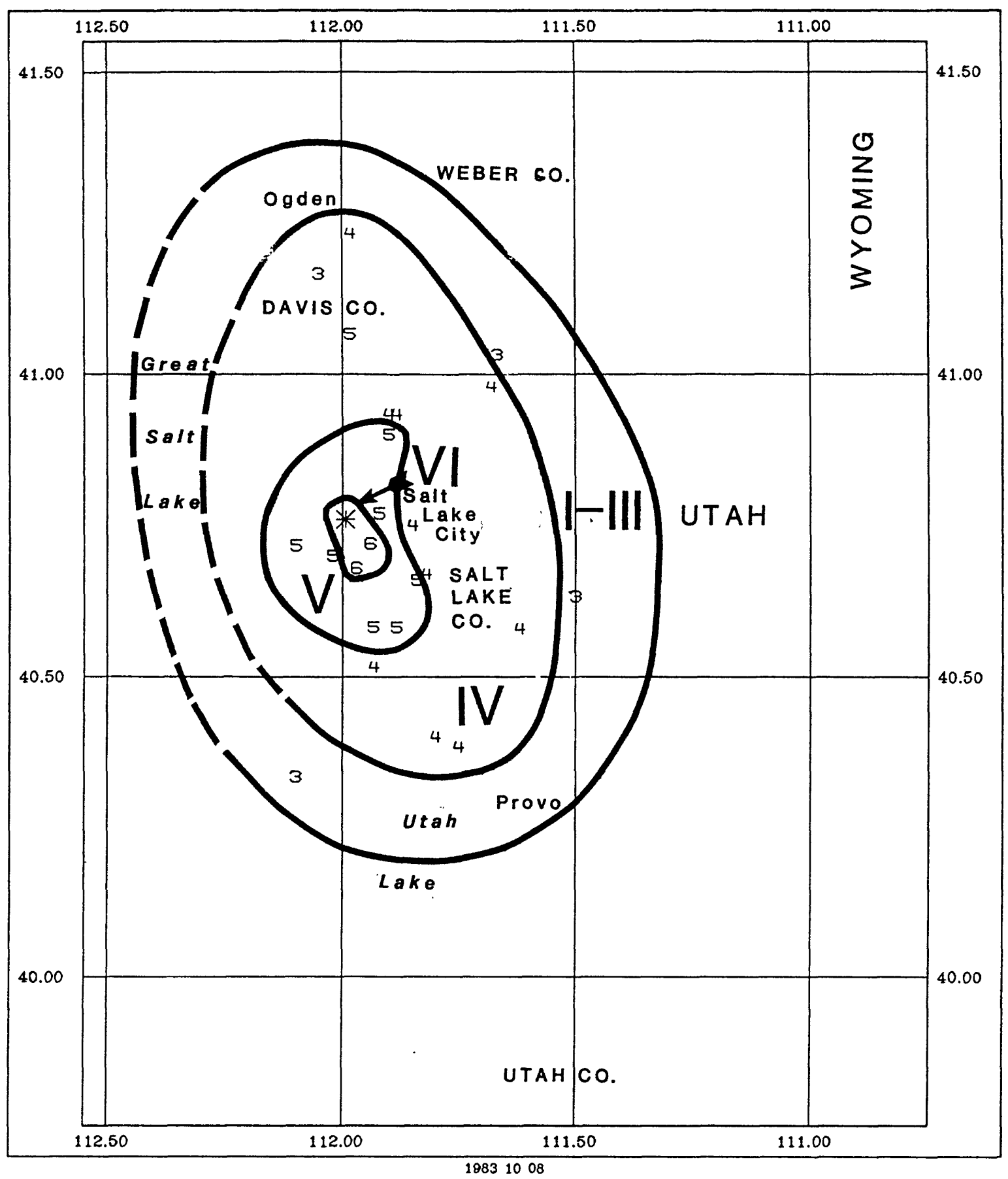

Figure 17. Isoseismal map for the earthquake of October 8, 1983, West Valley City, Utah. The maximum Modified Mercalli intensity is $V I ; M_{L}$ is 4.3 . The star indicates the epicenter. The numbers indicate site intensities and the roman numerals indicate isoseismal intensities (MMI). Isoseismals are by the author. 


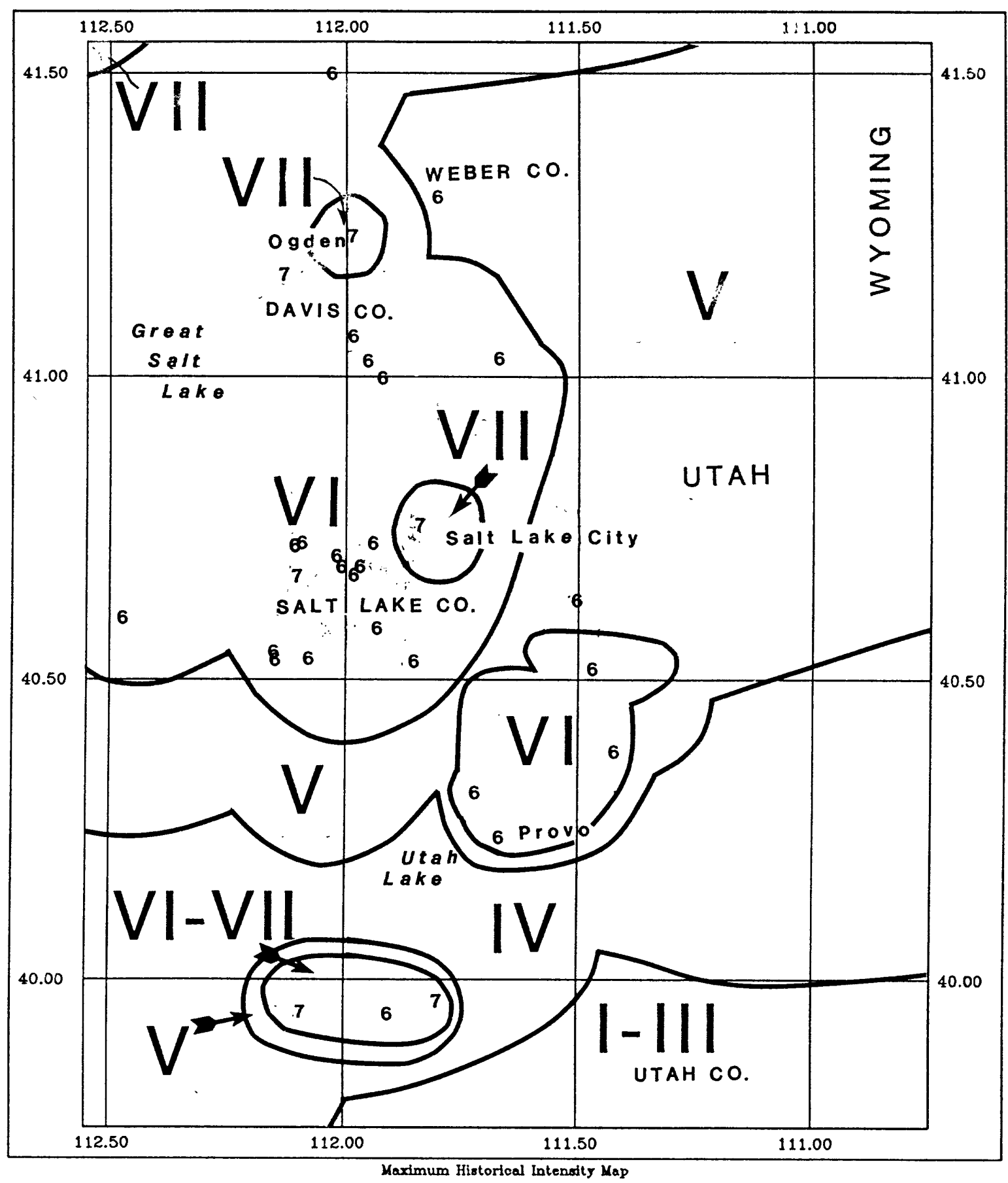

Figure 18. Maximum historical intensity map for the Utah counties of Weber, Davis, Salt Lake, and Utah. Contours and roman numerals indicate areas of highest historical isoseismals (MMI) based on the maps in figures 3-17. Arabic numbers indicate historical site intensities strong enough to cause damage (MMI $\geq \mathrm{VI})$. Note that the outlying high intensities (for example. 7's in the VI area) are all due to the larger distant earthquakes (Hansel Valley and Cache Valley). 
Intensities from two of the earthquakes (1934 Hansel Valley, and 1962 Cache Valley) override most of the map. These two large shocks determine the intensities for wide areas. Small areas of higher intensities within these wide areas are caused by local shocks.

Three other sets of earthquakes deserve mention in connection with the maximum intensity map.

(1) The 1975 Pocatello Valley, Idaho, earthquake (figure 19) caused high intensities across the northern part of Utah (Stover and others, 1986b; Coffman and Stover, 1977). However, nowhere within the study area did its isoseismals exceed those of the 1962 Cache Valley earthquake, and nowhere did its damage-level isoseismals (MMI $\geq \mathrm{VI}$ ) intrude upon the four-county study area. Therefore the 1975 shock was not included in this study.

(2) The group of shocks in Sevier County, Utah (figure 20), includes shocks with maximum intensities $I_{o}$ that have been estimated from VII to IX (one in 1901 and three in 1921) (Townley and Allen, 1939; Williams and Tapper, 1953; Coffman and others, 1982; Stover and others, 1986a; Hopper, 1988). All these shocks have very rapid intensity attenuation and frequently were not felt much beyond the county borders; they are probably extremely shallow events. The 1901 event, which was reported felt in Salt Lake City, could have produced isolated damaging intensities within the southern part of the study area. There is not enough data available for these earthquakes to know for certain.

(3) Several small local earthquakes were not included because little is known about their intensity distributions, and their epicentral intensities are no higher than other, better known shocks at nearby epicenters. For example, shocks in 1894 and 1949 produced MMI VI at their epicenters at Ogden and Salt Lake City, respectively, but the effects of the shocks beyond those cities are unknown. Neither earthquake affects the maximum intensity map (figure 18) because both locations already show MMI VII from earthquakes in 1915 (figure 4, VII at Ogden) and 1910 (figure 4, VII at Salt Lake City). 


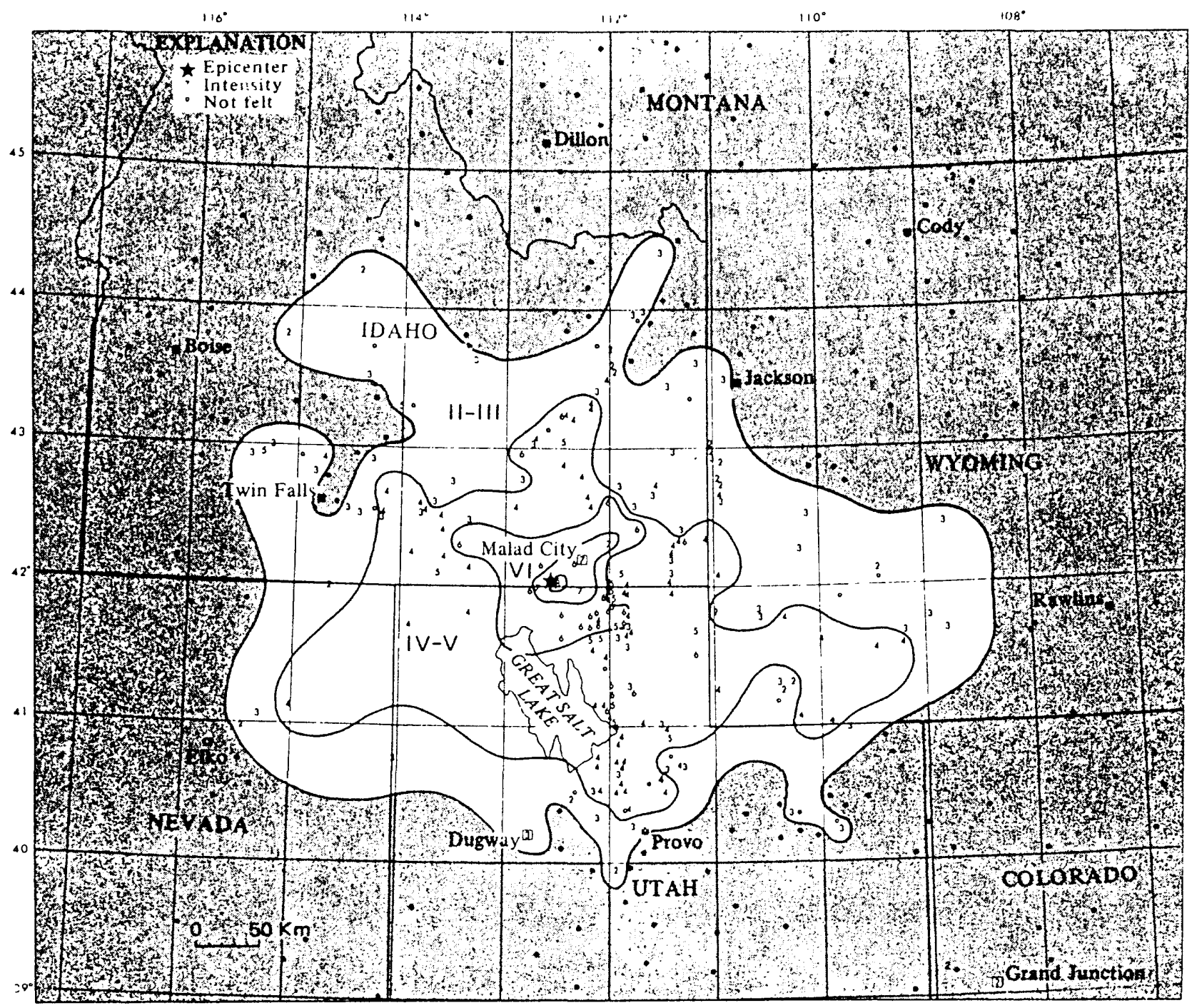

Figure 19. Isoseismal map for the earthquake of March 28, 1975, Malad City and Pocatello Valley, Idaho. The maximum Modified Mercalli intensity is VIII; $M_{L}$ is 6.0. The star indicates the epicenter. The numbers indicate site intensities and the roman numerals indicate isoseismal intensities (MMI). The map is from Coffman and Stover (1977). The area of this study is indicated by the rectangle. 




(a)

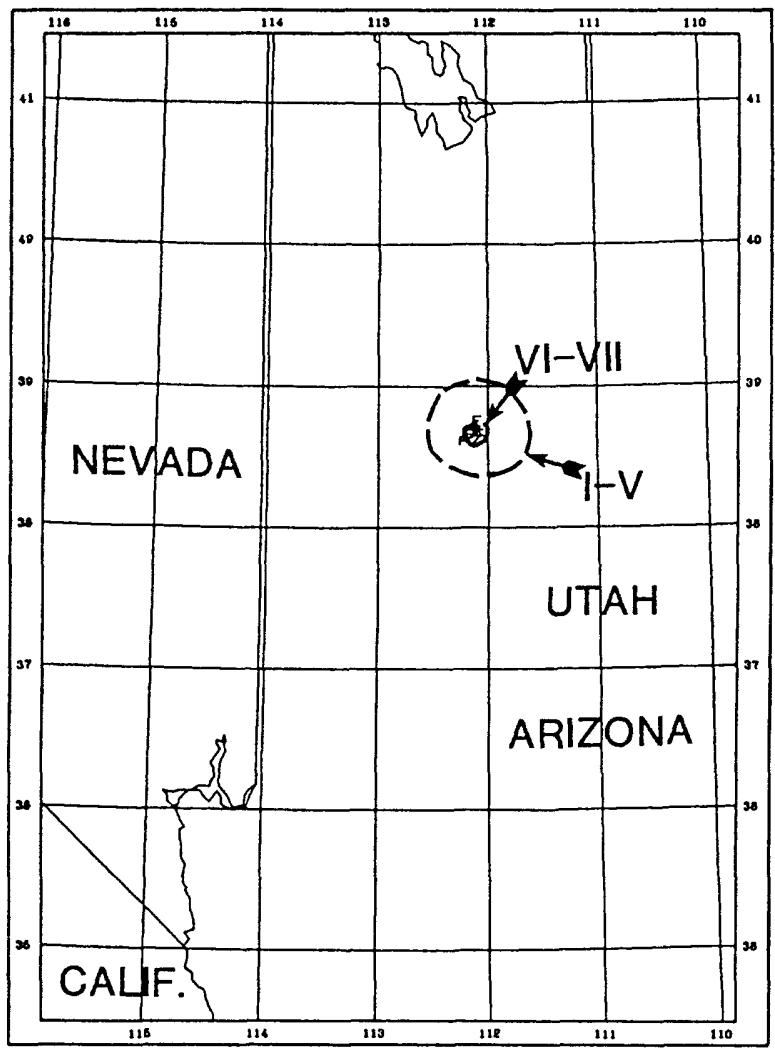

(c)
10011113

1001002010.30

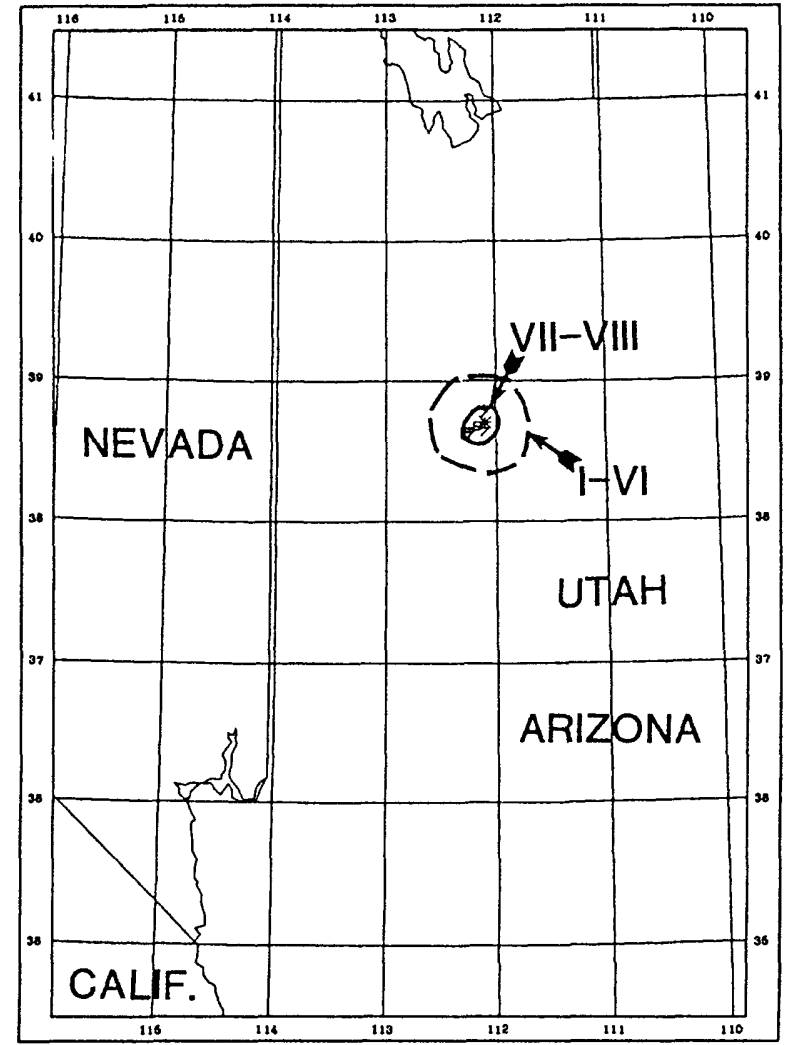

(b)

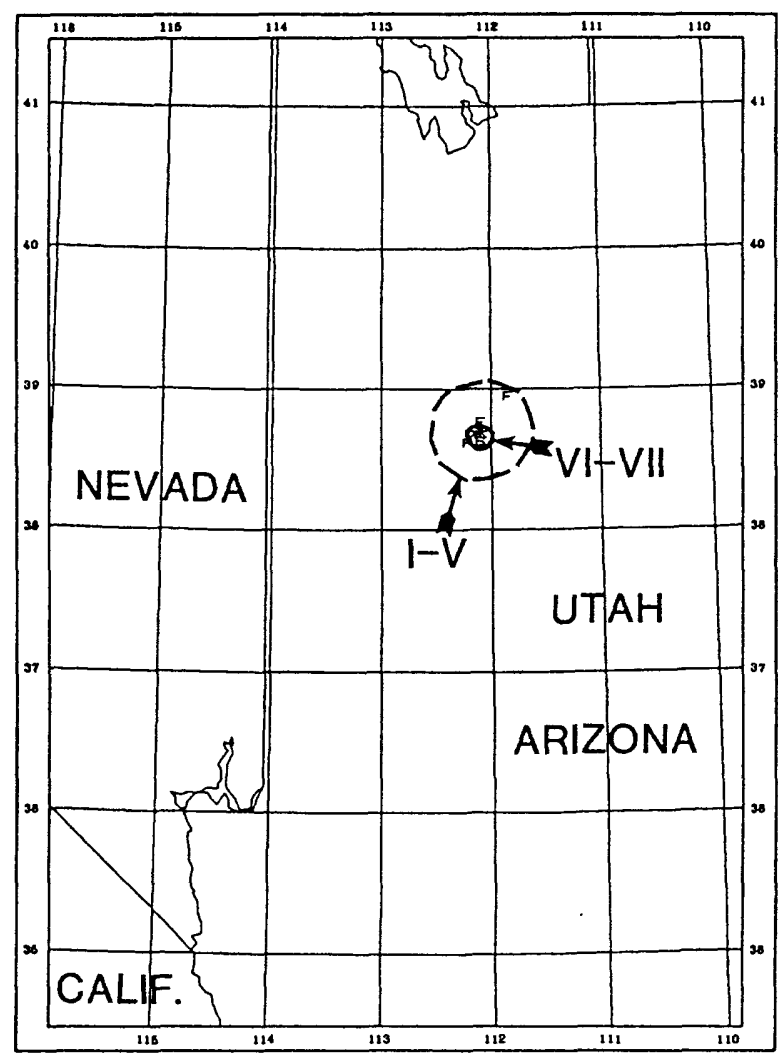

(d)

10211001

Figure 20. Isoseismal maps for the Sevier County, Utah, earthquakes of (a) November 14, 1901, (b) September 29. 1921. (c) September 30, 1921, and (d) October 1. 1921. The stars indicate the epicenters. The numbers indicate site intensities and the roman numerals indicate isoseismal intensities (MMI). ' $F$ ' is used for reports of 'felt' that were not assigned MMI's. Isoseismals (dashed where uncertain) are by the author. 


\section{REFERENCES CITÉD}

Arabasz, W. J., and McKee, M. E., 1979, Utah earthquake catalog 1850-June 1962 in Arabasz, W. J., Smith, R. B., and Richins, W. D., eds., Earthquake studies in Utah 1850 to 1978: University of Utah Seismograph Stations Special Publication, p. 119-143.

Berg, J. W. Jr., and Resler, R C., 1958, Investigation of local earthquakes February 13, 1958, near Wallsburg, Utah: Utah Academy of Science, Arts, Lett. Proc., v. 35, p. 113-117.

Bodle, R. R., 1945, United States earthquakes, 1943: U. S. Coast and Geodetic Survey, 49 p.

Brazee, R. J., and Cloud, W. K., 1960, United States earthquakes, 1958: U. S. Coast and Geodetic Survey, $76 \mathrm{p}$.

Coffman, J. L., and Stover, C. W., 1977, United States earthquakes, 1975: National Oceanic and Atmospheric Administration and U. S. Geological Survey, 136 p.

Coffman, J. L., and von Hake, C. A., 1974, United States Earthquakes, 1972: U. S. National Oceanic and Atmospheric Administration, 119 p.

Coffman, J. L., von Hake, C. A., and Stover, C. W., 1982, Earthquake History of the United States (Reprinted with Supplement): U. S. National Oceanic and Atmospheric Administration and U. S. Geological Survey, 208 p. plus 50-p. supplement.

Cook, K. L., 1979, Effects of the earthquakes in the Magna area, Salt Lake County, Utah, during February-March 1978 in Arabasz, W. J., Smith, R. B., and Richins, W. D., eds., Earthquake studies in Utah 1850 to 1978: University of Utah Seismograph Stations Special Publication, p. $475-485$.

Hopper, M. G., 1988, Large earthquakes in Sevier County, Utah, in 1901 and 1921: U. S. Geological Open-File Report 88-44, 18 p.

Lander, J. F., and Cloud, W. K., 1964, United States earthquakes, 1962: U. S. Coast and Geodetic Survey, $114 \mathrm{p}$.

Neumann, Frank, 1936, United States earthquakes, 1934: U. S. Coast and Geodetic Survey, 99 p.

Stover, C. W., ed., 1984, United States earthquakes, 1981: U. S. Geological Survey Special Publication, $136 \mathrm{p}$.

Stover, C. W., ed., 1987, United States earthquakes, 1983: U. S. Geological Survey Bulletin 1698, $196 \mathrm{p}$.

Stover, C. W., Reagor, B. G., and Algermissen, S. T., 1986a, Seismicity map of the state of Utah: U. S. Geological Survey Miscellaneous Field Studies Map MF-1856, 1:1,000,000.

Stover, C. W., Reagor, B. G., and Algermissen, S. T., 1986b, Seismicity map of the state of Idaho: U. S. Geological Survey Miscellaneous Field Studies Map MF-1857, 1:1,000,000. 
Stover, C. W., and von Hake, C. A., 1980, United States earthquakes, 1978: U. S. Geological Survey and National Oceanic and Atmospheric Administration, 112 p.

Townley, S. D., and Allen, M. W., 1939, Descriptive catalog of earthquakes of the Pacific Coast of the United States, 1769 to 1928: Seismological Society of America Bulletin, v. 29, no. 1, p. 1-297.

Williams, S. J., and Tapper, M. L., 1953, Earthquake history of Utah, 1850-1949: Seismological Society of America Bulletin, v. 43, no. 3, p. 191-218.

Wood, H. O., and Neumann, Frank, 1931, Modified Mercalli intensity scale of 1931: Seismological Society of America Bulletin, v. 21, no. 4, p. 277-283. 
SEISMIC RISK METHODS AND ESTIMATES

FOR UTILITY SYSTEMS AND STATE-OWNED

BUILDINGS ALONG THE WASATCH FRONT

By

Craig E. Taylor ${ }^{1}$, Delbert B. Ward ${ }^{2}$, and Jerold M. Haber ${ }^{3}$

\section{ABSTRACT}

This paper summarizes the methodology and results of two seismic risk projects on Utah facilities. The topics selected in these projects are explained in relation to past seismic risk projects on Utah facilities and in relation to potential uses of seismic risk estimates. Results are highlighted with reference to project goals. A longer discussion of methods used and technical obstacles addressed indicates the iterative nature of seismic risk projects. Finally, a more detailed presentation of results is made. Detailed results in the form of computer printouts of expected earthquake damage have been presented to specific users, namely local culinary water and natural gas utility officials and to the State of Utah Risk Administrator.

INTRODUCTION AND SUMMARY

In early 1985 we began a one-year U.S.G.S. sponsored project to examine (1) expected losses and casualties in state-owned buildings as a result of a maximum credible earthquake and (2) expected damage to culinary water and natural gas facilities in Salt Lake and Davis counties as a result of a broad range of possible earthquakes affecting

1Dames \& Moore, Los Angeles, California 2Structural Facilities, Inc., Salt Lake City, Utah

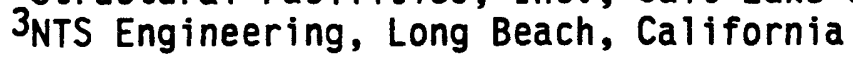


them. In early 1987, we began a second one-year U.S.G.S. sponsored project to examine expected damage to water and gas facilities in Weber and Utah counties as a result of a broad range of possible earthquakes affecting them.

Project topics were selected so that (1) they did not duplicate previous work or work in progress (these include [1], [2], [3], [4], [5], [6], [7], and [8], as illustrations) (2) project results could illuminate some of the more recent methodological and data developments in the geosciences and engineering as they pertained to the region of study and (3) project results might assist in advancing earthquake hazard reduction programs. As a result of this third consideration, for instance, we decided not to re-examine average annual loss estimates for various classes of buildings. Although new findings would likely change and improve those estimates (as found in [5], for instance), we did not believe that significant policy conclusions would change from those developed in [9] and [10]. Furthermore, this third consideration implied that the primary project outputs, detailed computer printouts of damage and casualty estimates, should be designed for those who might use them, the State of Utah Risk Administrator and utility officials whose systems were analyzed.

Results of the first project reaffirm that shaking losses and potential casualties would be severe for state-owned buildings affected by a maximum credible earthquake (whether from the Salt Lake or the Ogden segment of the wasatch fault). Principal factors affecting results are the magnitude of these maximum credible earthquakes (Ms 7.0 to 7.5), the close proximity of exposures to the Wasatch fault at depth, and the seismic vulnerability of many state-owned buildings. Further study of the seismic vulnerability of state-owned structures -especially with respect to life-safety factors -- could greatly assist 
in identifying those structures most vulnerable and hence in need of long-term removal, replacement, or occupancy reduction. Whether or not the current State of Utah practice of self-insurance is adequate to respond to expected damage state-owned buildings deserves careful review based on results of this study.

While building damage from these maximum credible events is expected to be severe, so is damage to and disruption of culinary water and natural gas systems. Except perhaps for the natural gas systems in Utah or Weber counties, local gas or water systems can be expected to have little or no immediate reliability when affected by a maximum credible Wasatch fault event that occurs in their county. Mountain Fuel Supply representatives have used detailed computer printouts of damage estimates made in this study in order to confirm this for their systems. The damage estimates for culinary water systems, containing much more seismically vulnerable facilities, were many times more severe than those for the natural gas systems.

In addition to the comparative vulnerabilities of facilities, factors primarily affecting these results include the magnitudes of these maximum credible events, the close proximity of the wasatch fault at depth to exposures, high soft soil site ampification factors for many exposures, and severe potential liquefaction problems especially near the Jordan River and the Great Salt Lake. Although fault zone crossings are significant, detailed results indicate that damage from fault displacement is generally only a small proportion of the overall expected damage to water and gas facilities.

An important characteristic of these projects is that we have emphasized smaller magnitude events (with magnitudes from 5.5 to 7.0 ) as much as maximum credible ones for two major reasons. First, owing to 
high liquefaction susceptibilities in the four counties, local water utility catastrophes can occur from earthquakes with many low magnitudes (possibly as low as 5.5 in some instances). Second, utility damage estimates from maximum credible earthquakes tend to be so high that no obvious limited measures can be used to improve immediate system reliability. In contrast, smaller magnitude earthquake scenarios can help utility officials to define those portions of the system that can be seismically enhanced in order to provide increased system reliability. Measures designed to increase system reliability in these smaller magnitude events also (1) tend to improve expected system performance (long-term reliability) through reduced expected damage in larger magnitude earthquakes as well and (2) tend to concentrate efforts on the more seismically vulnerable portions of systems -- those portions expected to be damaged from a wide variety of potential earthquakes.

Some of the more important methodological problems encountered in these projects are highlighted below. Methodological revisions from the first project to the second have included incorporations of changes made by $K$. Campbell in defining attenuation functions for the Wasatch Front region, simplifications in the fault models used as a consequence of findings in the first project, and adjustments in damage algorithms for pipelines subjected to severe ground-shaking. To estimate probabilities of liquefaction-induced ground failure, makeshift methods had to be devised for both projects. Our study findings strongly suggest the need to develop a research program to assess probabilities. This would include an empirical and/or experimental reassessment of multipliers used to adjust critical accelerations to account for effects of different numbers of cycles of shaking. Although seismic risk methods used often require working assumptions or imperfect data, these are best approached by (1) sen- 
sitivity and other statistical analyses that determine the impact of alternative assumptions and (2) continued investigations in science and engineering to improve pertinent information and algorithms used.

METHODS AND ASSUMPTIONS

A significant consideration in structuring a data base for these projects is the selection of a basic geographic reference system. The system selected has been the township system, shown in Figure 1 for the primary study area. In the course of these projects, many advantages and disadvantages of this system have become apparent. A very compelling advantage for these risk projects has been its widespread and customary use by those who select pertinent data and by potential users of data and results. Two examples of this are the culinary water systems of Granger-Hunter (in Salt Lake County) and Orem (in Utah County) which are laid out on the township system. Disadvantages arise because the ideal microzone size varies with particular purposes. Thus, use of township sections (one mile by one mile) as microzones are, at times, too large or too small. 2504 microzones were used for the study area. In some cases, especially in Weber and Utah counties, liquefaction susceptibility data developed by Utah State University and Dames \& Moore are too sparse to make meaningful estimates for each microzone. In other cases, these data are diverse enough to suggest that smaller microzones might be desirable. On the whole, however, given the large number of microzones used, the township system has been adequate for study purposes.

Figure 2 outlines the primary hazard steps in these projects. Unique to this approach in Utah seismic risk studies is the choice of many earthquake scenarios representing the gamut of possible magnitudes and the range of rupture locations which may damage exposures in the study 


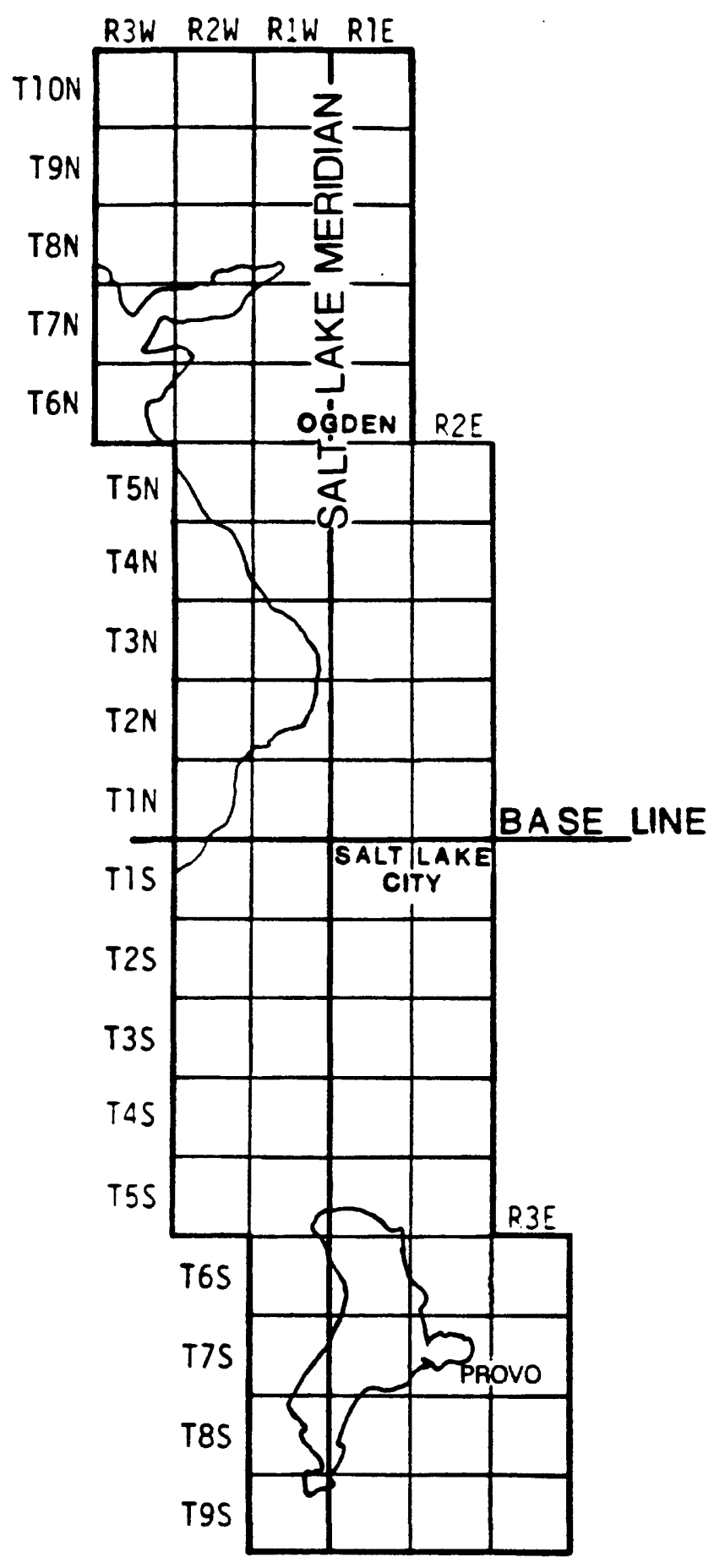

FIGURE 1. Studies Areas: Exposures in Weber, Davis, Salt Lake, and Utah counties 


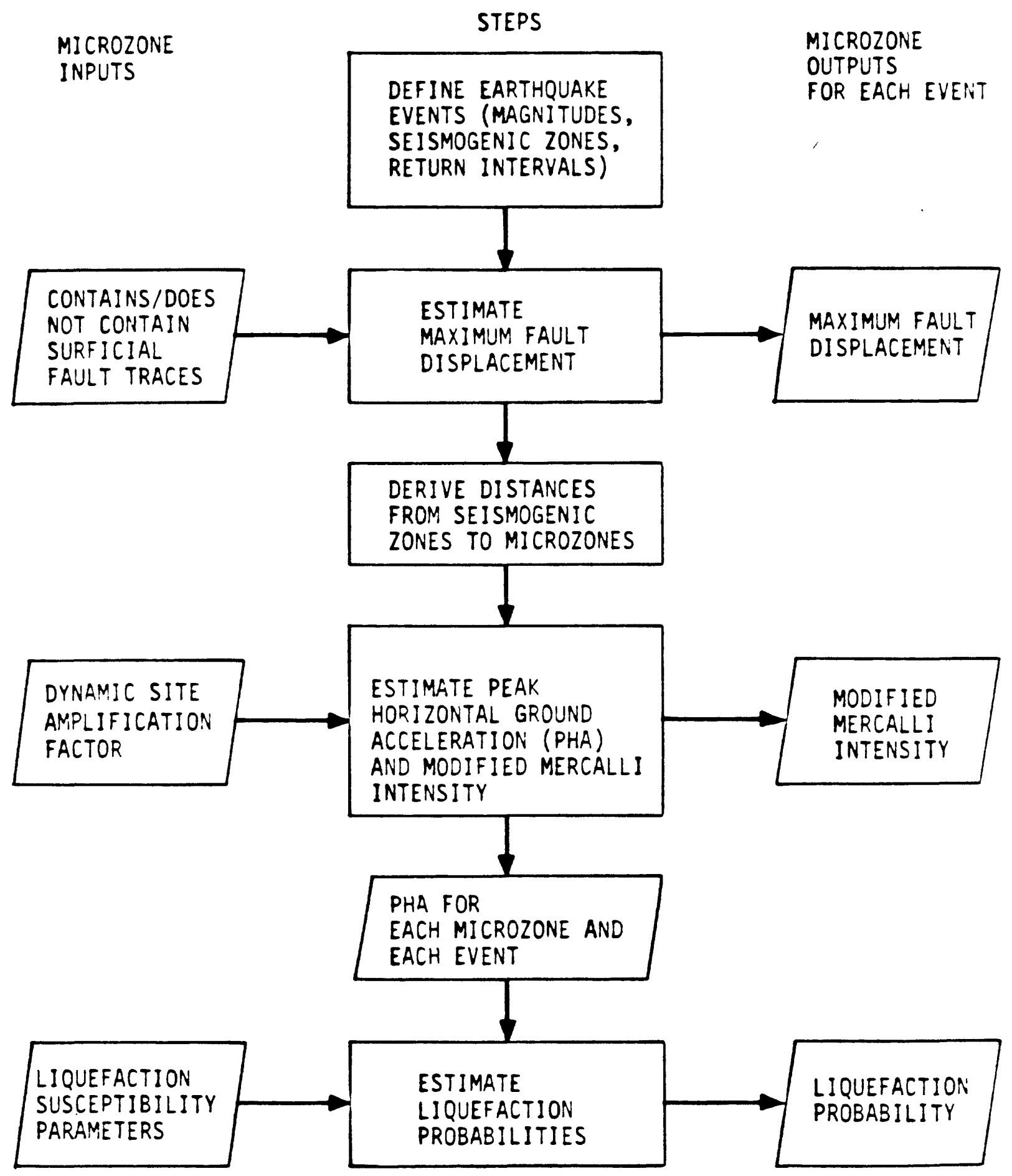

Figure 2. Hazard Assessment Procedures Used 
area. The annual probabilities of the magnitude and rupture location occurrences can be assessed in order to place risk results within a probabilistic framework. We shall now explain why multiple scenarios were selected rather than either selecting maximum ones only or else selecting methods to develop probabilistic estimates of hazards affecting individual sites. Then we shall describe how these earthquake scenarios are selected to accommodate a probabilistic framework.

A severe limitation of using only maximum credible earthquakes has been that it greatly underestimates long-term primary losses expected from earthquakes and hence benefits of seismic risk reduction measures. To draw an analogy from California, exclusive concern with potential losses from major San Andreas faulting earthquake scenarios (affecting either San Francisco or Los Angeles) would ignore losses from Whittier, Coalinga, Imperial Valley, San Francisco Valley, Long Beach, and Hayward events -- to name a few. Total estimated benefits from earthquake hazard reduction measures comprehend the entire range of potential earthquakes.

One traditional weakness of procedures designed to estimate total primary losses and benefits from all earthquakes potentially damaging facilities has been that these procedures ignore or provide a poor account of the secondary losses including systematic consequences of individual earthquakes. These include business interruption losses, governmental discontinuities, fires, losses of heating and lighting, water and gasoline shortages, and problems of caring for the homeless. These sorts of losses are clearly illustrated with respect to lifeline networks, for which direct dollar loss is not linearly related to system performance. In a highly redundant portion of a system, service may continue at pre-disaster levels even though direct dollar loss is large. In a portion of a system that has no alternative ser- 
vice paths or supply sources, damage to a single facility may cause extensive service outages over a long period of time. Traditional probabilistic approaches also have difficulties treating resources that are limited, such as inventories of piping, local medical personnel, local capital for reconstruction, and insurance reserves available for paying the insured. Use of individual scenarios to evaluate earthquake risks has the advantage of indicating whether or not specific critical levels of resources will be surpassed for given events as well as how soon critical infrastructure services will be available for use in response, recovery, and reconstruction.

Accordingly, the approach used in these projects has been to use a large number of individual scenarios within a probabilistic framework. This approach overcomes limitations of traditional probabilistic approaches and of emphasis on only a small set of earthquake scenarios -- chiefly maximum credible ones.

To accommodate this probabilistic framework, we have first treated major fault traces as sequences of straight lines. These include the Granger fault, the Hansel Valley fault, the Cache Valley fault, the Taylorsville fault, and various segments of the Wasatch fault ([12], [13]). For the sake of simplicity, we have followed Wheeler [14] in modeling the Wasatch fault as consisting of four persistent segment boundaries and five main segments: a northernmost, the Weber, the Salt Lake, the Provo, and a southernmost. Relative to exposures examined in this project, the chief controversial aspect of this treatment is that it permits larger magnitude events to be possible on the Provo segment than would be available if the smaller American Fork $(22.5 \mathrm{~km})$ and Provo $(18.5 \mathrm{~km})$ segments were used to define maximum earthquakes in this region (see [15]). 
As recent 1987 Whittier Narrows and 1983 Coalinga, California earthquakes have shown, not all earthquakes occur on fault zones known to be active and few normal or thrust zones have been mapped at depth ([16], [17]). Accordingly, our treatment of possible earthquakes permits the development of a random source zone and also designation of a dip angle for whatever fault system is used. Some random source zones for the Wasatch fault region have included very narrow zone, between ten and twenty $\mathrm{km}$ on each side of the Wasatch fault ([5], [18]). other accounts of background seismicity (earthquakes with magnitudes below 6.5) have employed a very wide random source zone [19]. Our method is to develop earthquakes along lines parallel to and at any specified distance from either a known fault trace (such as the Wasatch) or a north-south line. To account for rupture lengths relative to specified magnitudes, we have used empirical work [20] relating magnitude and rupture length for all fault systems. Given these rupture lengths, a number of earthquakes can be specified from north to south along the designated sequence of lines (representing fault traces, lines parallel to fault traces, or lines parallel to north-south lines). Our method is therefore compatible with either very narrow or very wide source zones and with either the view that an entire Wasatch fault segment must rupture in a Wasatch fault event or that only a portion of a given Wasatch fault segment may rupture.

Designation of a dip angle enables us to provide a crude account of distances for exposures to the Wasatch fault at depth. Currentiy, models of the Wasatch normal fault are either listric or planar [21]. In our first project, we explored the use of a complex planar model hypothesized by $R$. Bruhn and others ([22], but modified in [23]). That model suggests that the Salt Lake segment of the Wasatch fault may be modeled as a series of rectilinear planes whose surface projections are shown in Figure 3. 


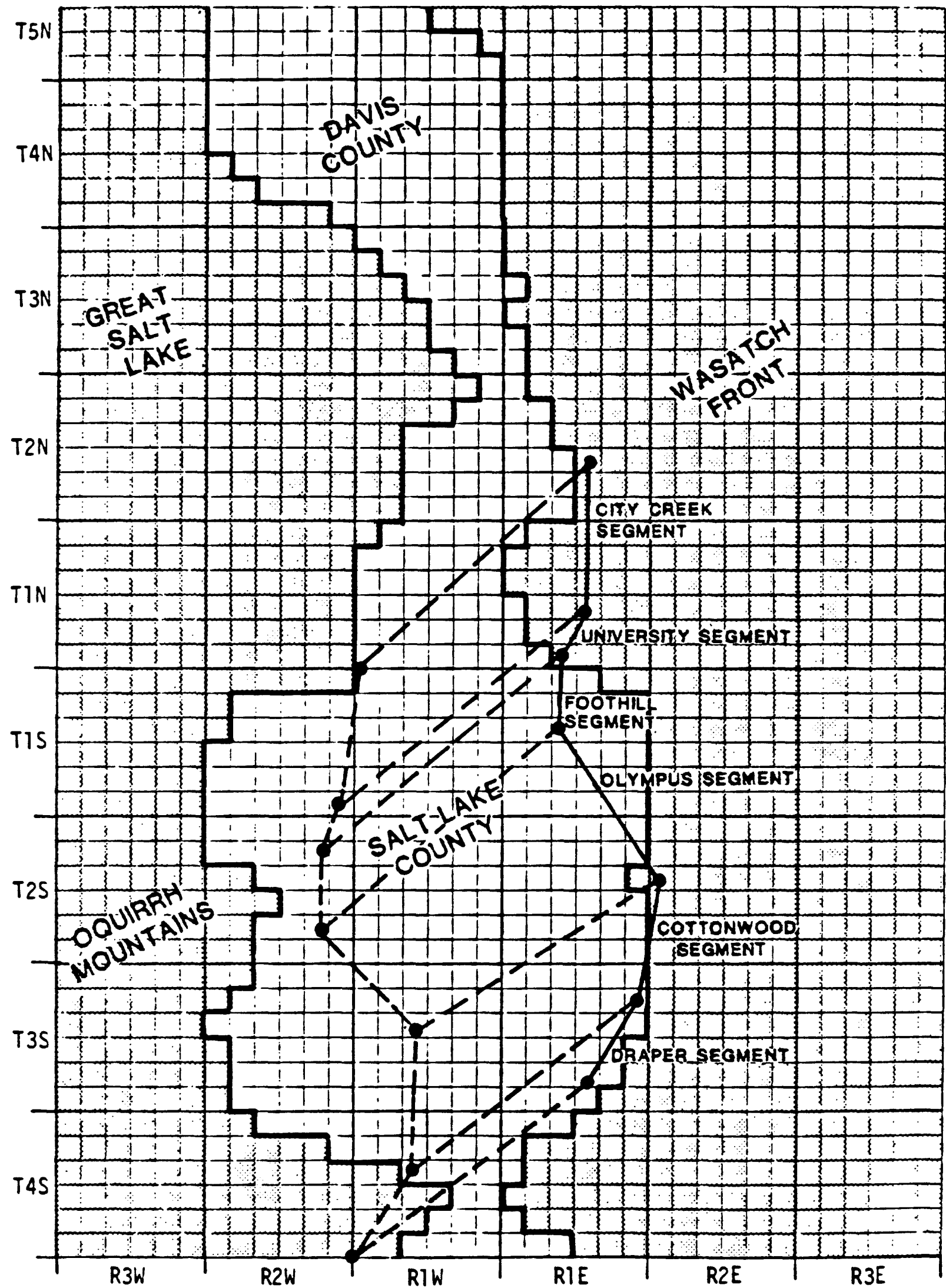

Figure 3. Plan View of Wasatch Fault System (Salt Lake Segment, $12 \mathrm{~km}$ Deep) Underlying Facilities in Salt Lake County

* Dashed lines indicate projection of fault planes to depth below the ground surface 
Table 1 indicates the assumed geometric characteristics of this segment, with Figure 4 clarifying the variables used in Table 1. This model derives itself from an attempt to derive a fairly constant slip vector for the planes composing the Salt Lake segment so that it becomes possible to model a single slip along all surc planes.

This model suggests that sites in Salt Lake County are much closer to the dipping planes of the Salt Lake segment of the Wasatch fault than would be estimated based on distances to the surface expression of this zone. Figure 5 shows estimated shortest distances to these wasatch fault planes as modeled in Figure 3. This figure suggests that for exposures to the west of the Wasatch fault trace (Salt Lake segment) distances to the surface trace are approximately twice distances to the fault at depth.

These findings, along with the presence of alternative Wasatch fault models (including listric ones) confirming the above result, have persuaded us that a designated dip angle is currentiy adequate for seismic risk purposes to model each Wasatch fault segment at depth. (In our current programs, this dip angle applies uniformly to each straight-line section of the segment; yariations in dip angles for each section, as implied in Table 1, might be slightly preferable.) Modeling distances to the surface expression of the fault has the disadvantage of ignoring the wasatch fault dipping planes underlying most exposures; more refined fault models -- worth exploring for their implications -- nonetheless have the disadvantage of not being fully corroborated.

Figure 5 illustrates how larger magnitude ( 6.5 and above) earthquakes from the Wasatch fault (especially the Salt Lake, Ogden, and Provo segments) are expected to affect many exposures in the near-field. 


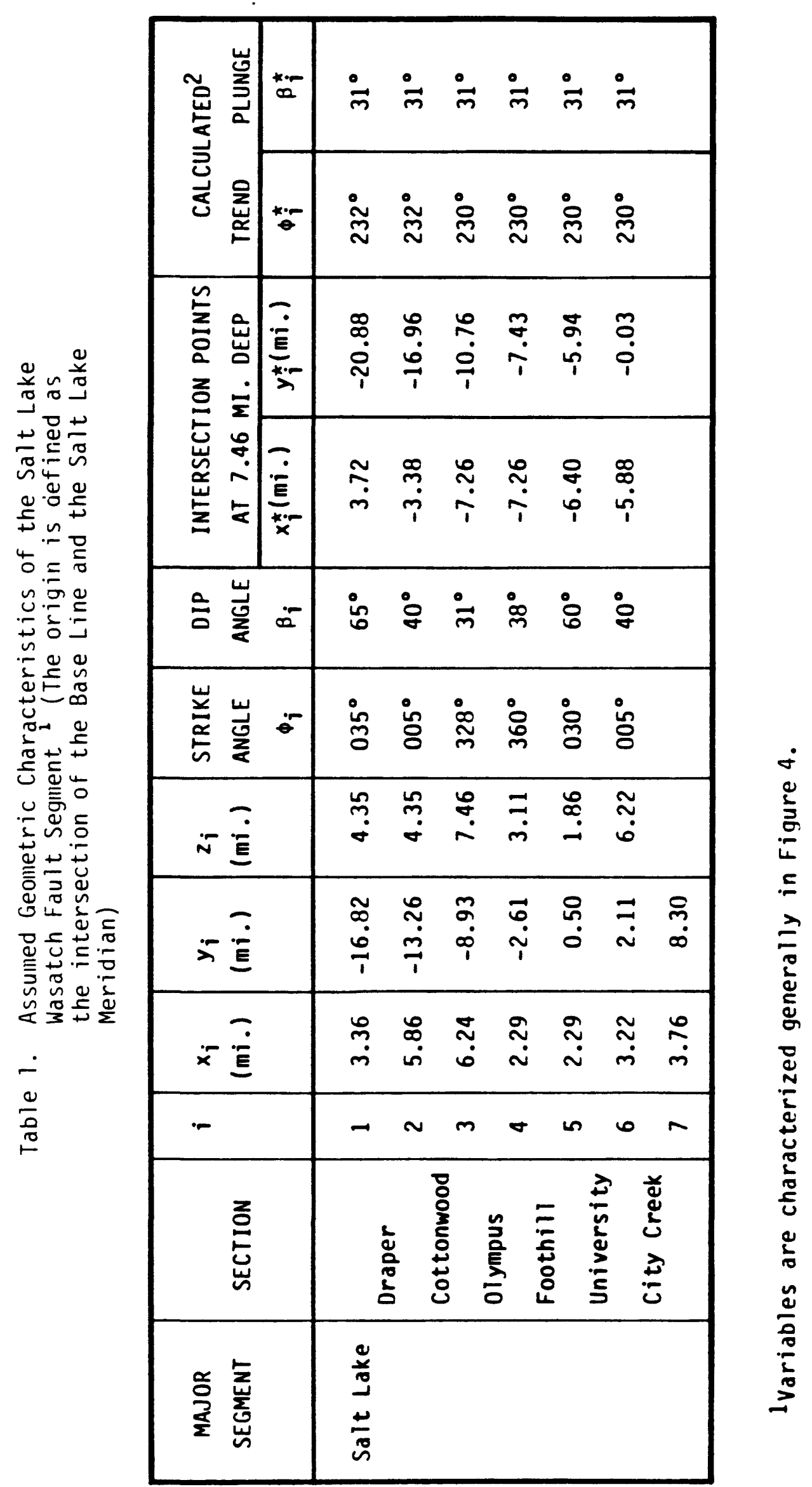




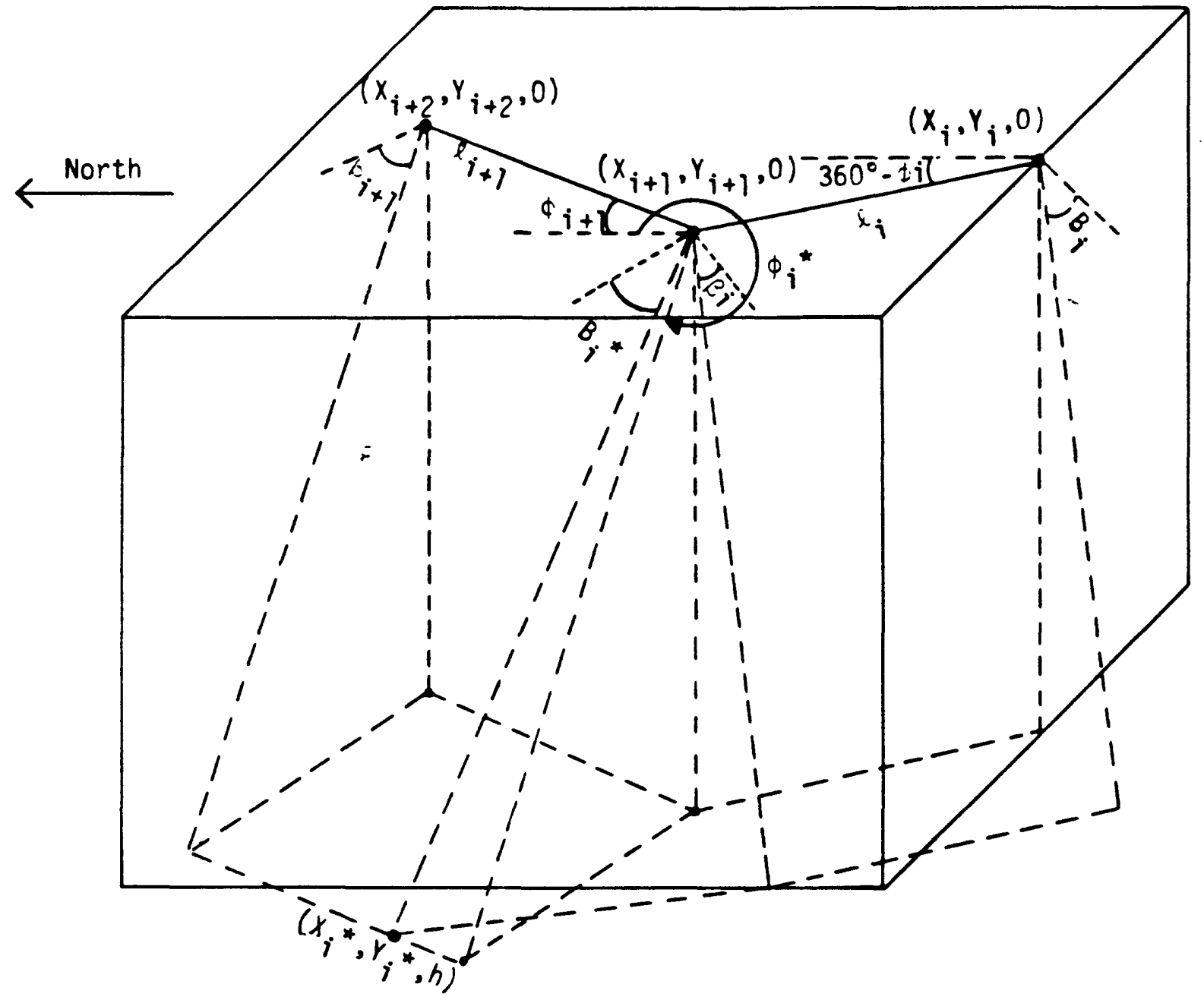

Notation: $\phi=$ strike angle

$E=$ dip angle (defined normal to each surface segment)

$\phi^{\star}=$ trend angle

$E^{\star}=$ plunge angle (calculated with respect to the line normal to ${ }^{*}$ )

$\hat{x}=$ length of surface trace

Figure 4. Two Three-Dimensional Rectilinear Fault Pianes Intersecting at $\left(X_{i}{ }^{\star}, Y_{i}{ }^{\star}, h\right)$ for Some Depth $h$ (No Elevations are Assumed on the Earth's Surface) 


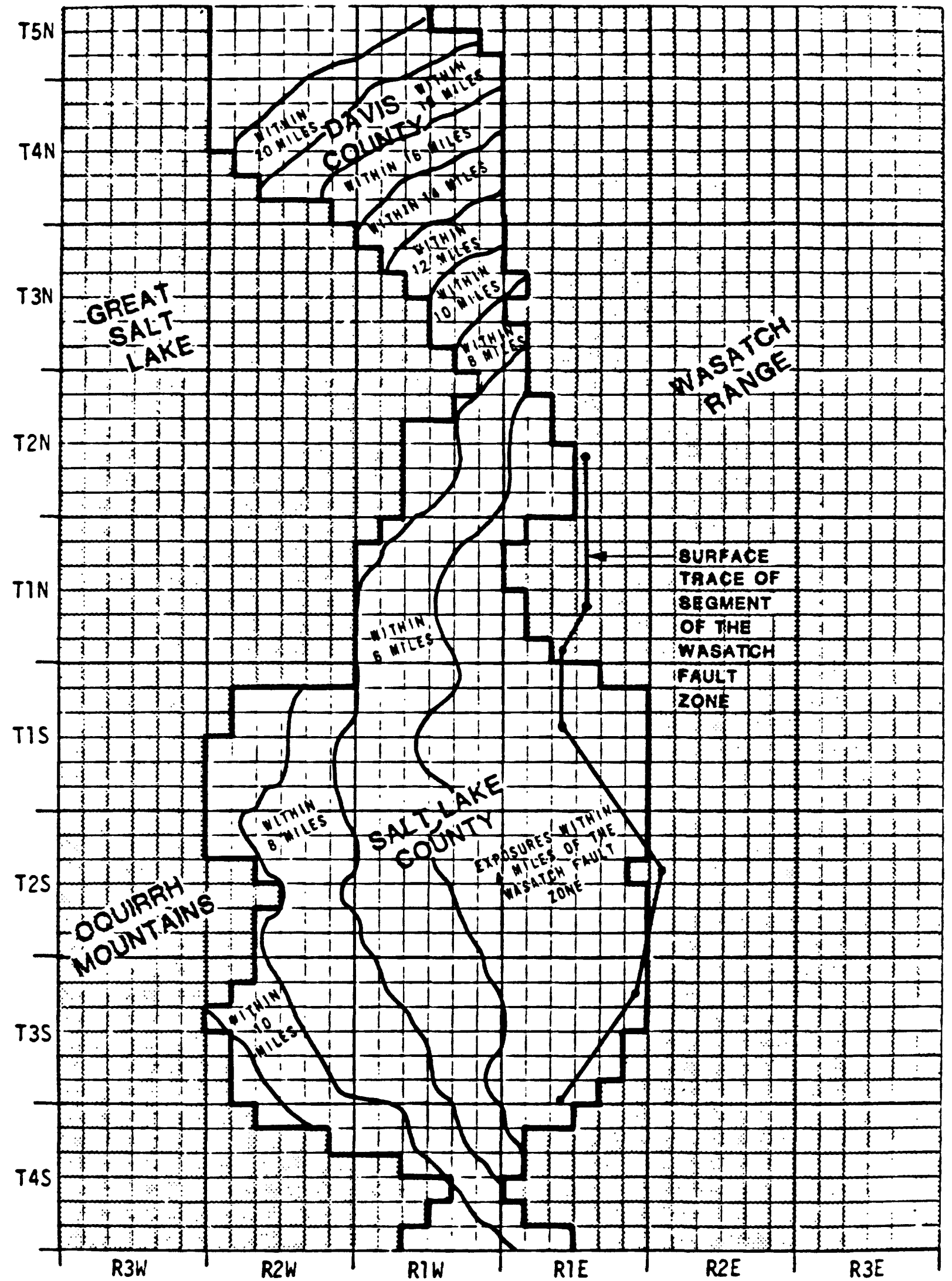

Figure 5. Isocontours Indicating Estimated Distances (miles) from Sites to the Salt Lake Segment of the Wasatch Fault Zone (Modeled in Three Dimensions) *Township Sections are $1 \mathrm{mi} \times 1 \mathrm{mi}$. 
Since the problem of defining attenuation patterns in the wasatch region includes this near-field aspect, and since large error terms hence arise in using attenuation functions based on hypocentral distance, K. Campbell's work ([11], [24]) has been used as a basis for developing both peak horizontal accelerations and Modified Mercalli intensities. For assessing peak horizontal acceleration (PHA, in units $g$ ) in the first project, the following equation from [24] was used:

$$
P H A=\exp [-2.817+0.702 M-1.02 \ln [R+0.0921 \exp (0.584 M)]]
$$

wherein

$M$ = Earthquake magnitude (Ms when $M>6$ and $M$ otherwise)

$R=$ The shortest distance to the seismogenic surface $(\mathrm{km})$ and

PHA = The mean of the two horizontal components of peak accelerations in units of $g$.

For the second project, following [11] we used the equation:

$$
\begin{gathered}
\text { PHA }=\exp (-3.303+0.850 M-1.25 \ln [R+0.0872 \exp (0.678 M)] \\
\left.-0.0059 R+\left(0.34 K_{1}+0.53 K_{2}+0.41 K_{3}\right)\right)
\end{gathered}
$$

wherein

$K_{1}=0$ for strike-slip faults and 1 for reverse and thrust faults

$K_{2}=0$ if the rupture is not directed toward the site (or directivity is unknown) and 1 if the rupture is directed toward the site

and

$K_{3}=0$ if soils are over $10-m$ deep and 1 otherwise. 
In programing these additional variables, we have permitted options to analyze the sensitivity of results to various selections of values for $K_{1}, K_{2}$, and $K_{3}$. For somewhat conservative results for the natural gas system, we have used $K_{1}=1, K_{2}=0$, and $K_{3}=1$ (rupture directivity is largely unknown). For less conservative results, we have used $K_{1}=$ $0, K_{2}=0$, and $K_{3}=1$. For sensitivity analyses, we have used $K_{1}=0, K_{2}$ $=0$, and $K_{3}=0$.

In order to derive estimates of Modified Mercalli shaking intensities, we have first developed estimates of peak horizontal velocities, and have derived estimated intensities from both relative response data for the region and an equation relating shaking intensities to peak horizontal velocity.

In the first project and following [24], we used the following equation in order to derive estimates of peak horizontal velocity (PHV):

$$
\mathrm{PHV}_{\text {rock }}=\exp (0.798+1.02 \mathrm{M}-1.26 \ln [R+0.015 \exp (0.812 \mathrm{M})])
$$

wherein

PHV = the median value of the mean of two horizontal components of peak velocity in $\mathrm{cm} / \mathrm{sec}$ (and "rock" refers to basement rock)

In order to derive surficial estimates of peak horizontal velocity, the following relationship was used:

$$
\mathrm{PHV}_{\text {surface }}=\left(\mathrm{DAF}_{\text {site }}\right) \mathrm{PHV}_{\text {rock }}
$$

wherein 
DAF $_{\text {site }}=$ soft surficial soil dynamic amplification factors.

Spectral values used in Equation (4) were derived for the short period band (0.2 - 0.7 seconds) results in [25], and as shown for Salt Lake, Davis, and Weber counties in Figure 6 . Spectral values tend to be slightly higher for the long-period band [0.7 - 1.0 seconds]. Nonetheless, as seen in Figure 6 , extensive portions of the study area were assigned spectral dynamic amplification factors of 6.2. The chief rationale for this procedure was that it yielded intensity increases of slightly over two relative to basement rock estimates.

In the second project, following [11] we have used the following equations to derive estimates of PHV:

$$
\begin{aligned}
\operatorname{PHV}_{c}= & \exp [-1.584+1.18 \mathrm{M}-1.24 \mathrm{ln}[R+0.00907 \exp (0.951 \mathrm{M})] \\
& -0.0059 \mathrm{R}+0.49 \mathrm{~K}_{1}+0.99 \mathrm{~K}_{2}+0.53 \mathrm{~K}_{3^{\prime}} \tanh (0.41 \mathrm{D}) \\
& \left.+0.60\left[1-\mathrm{K}_{3^{\prime}}\right] \tanh (0.88 \mathrm{D})\right]
\end{aligned}
$$

wherein

$\mathrm{PHV}_{\mathrm{C}}=$ peak horizontal velocity normalized primarily to California earthquake data

D = the depth $(\mathrm{km})$ of sediments beneath the site (i.e., depth to basement rock)

and

$K_{3^{\prime}}=0$ for buildings over 4 stories and 1 otherwise.

For estimates of depth to basement rock we have used maps developed by Mabey [26] and shown in Figure 7. Following K. Campbell [11], we have used $K_{3}{ }^{\prime}=1$ to establish upperbound median estimates of PHV, and for 


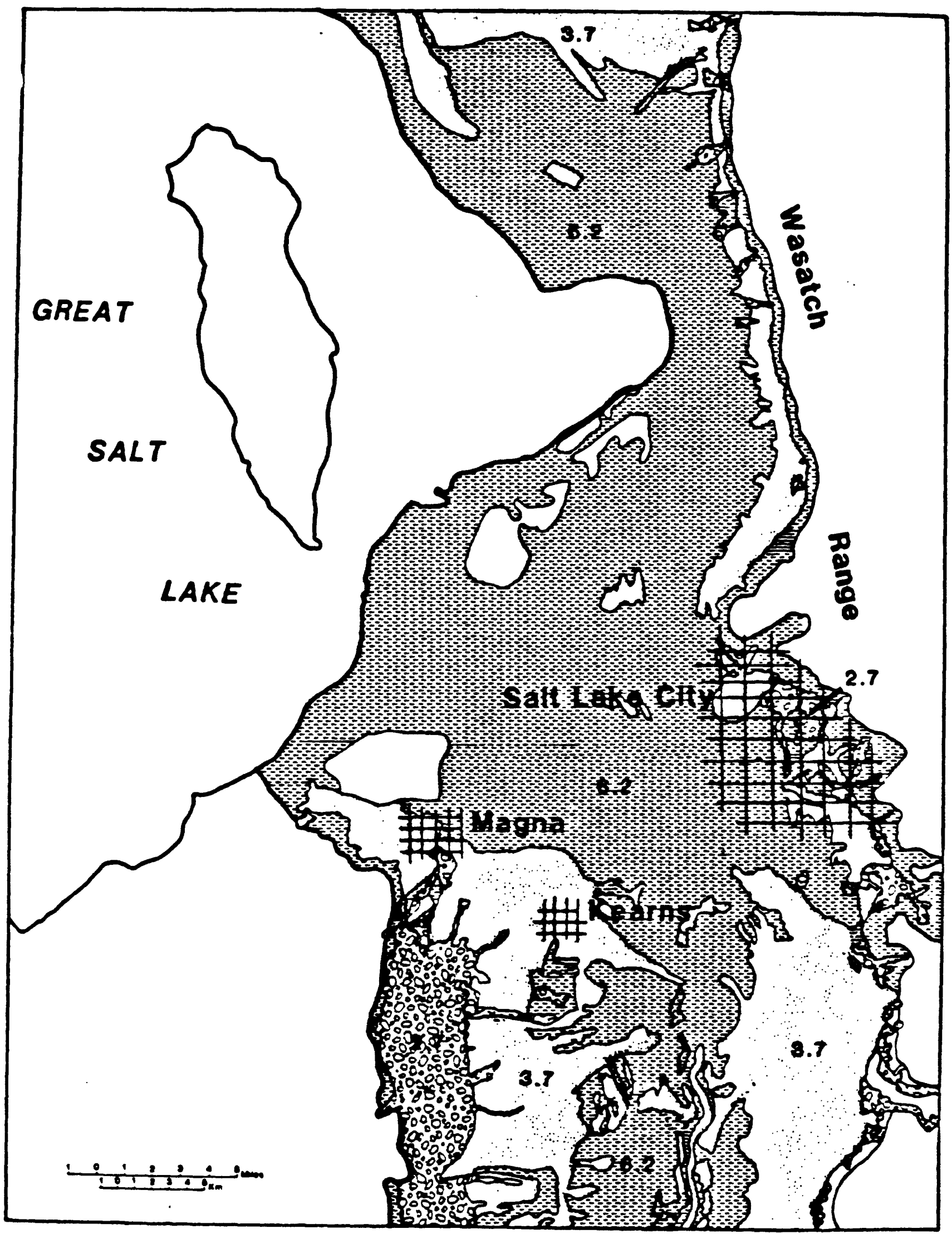

Figure 6. A Map Depicting Expected Relative Ground Shaking Response in the Central Part of the Wasatch Front Urban Area. The Numbers Indicate Mean Ground Response Relative to Bedrock Locations. ([25]) 


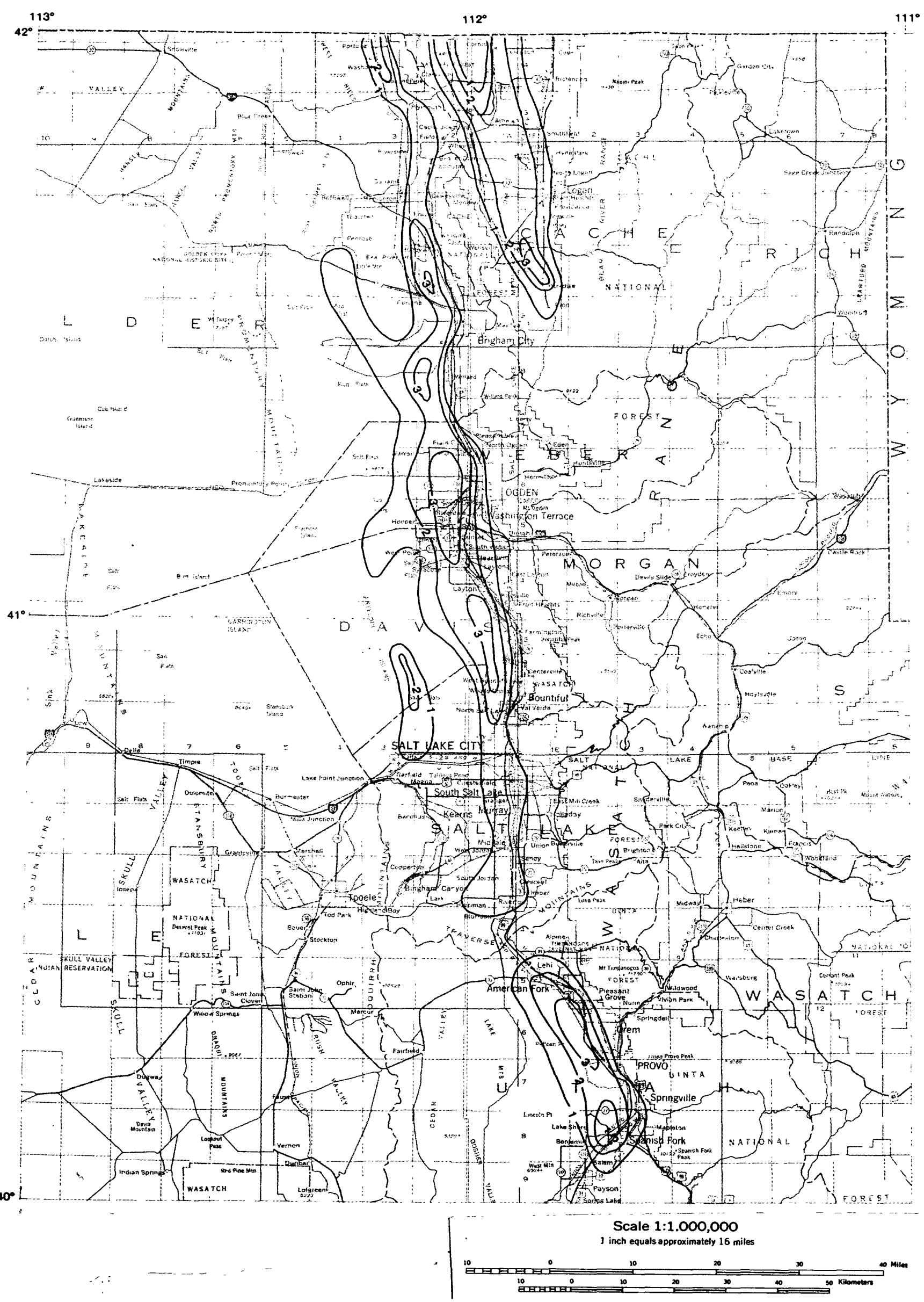

Figure 7. Thickness of low-density sedimentary rocks in Wasatch Front Valleys and Cache Valley inferred from gravity data. Contour interval is $1 \mathrm{~km}$. 
establishing estimates of PHV surface we have adapted remarks by Campbell in the following equation:

$$
\text { PHV surface }=\frac{\left(\text { PHV }_{C}\right)\left(\text { DAF }_{\text {site }}\right)}{4.0}
$$

This equation assists in adjusting for the high relative site response factors found along the Wasatch fault. We have again used $k_{1}=1$ for somewhat conservative results (for the natural gas system). The value of 4.0 in the denominator of equation (6) is used because $K_{3}^{\prime}=1$ already includes site amplification factors typical of California soft soils, with relative site response factors generally between 3.6 and 4.5 (see $[11])$.

To derive estimates of shaking intensities we have used the following equation from [27]:

$$
I=\frac{\log \text { PHV }_{\text {surface }}+1.484}{0.366}
$$

The notion of intensity used here is that of shaking intensity only. Such ground failure effects as liquefaction are accounted for with reference to input strong motion values, such as PHA, and hence are excluded from the shaking intensity scale implied here. Given equations (4) and (7), sites having soft surficial soil amplification values of 6.2 are assumed to have intensities exceeding basement rock values by over two intensity increments. Given equations (6) and (7), sites having amplification values of 6.2 exceed normal soft soil sites (chiefly from California earthquake data) by one-half intensity increment. These simplifying relationships should be used only for general planning purposes in as much as effects of high-strain, surface faulting, and seismic radiations are not accounted for. 
Obviously, values derived using these equations depend significantly on how distances from sites to the seismogenic source are estimated. As compared with results using a three-dimensional model, illustrated in Figure 1, one may as a rule-of-thumb state that distances in the near field of an earthquake from the Salt Lake segment of the Wasatch fault are overestimated roughly by a factor of two if they are calculated from the surface trace of this fault. More generally, if the dip angle is $B$, the distance is overestimated by a factor of $1 / \cos \beta$. Based on equation (2), the relative decrease in PHA to near-field sites and resulting from estimating distances to the surficial trace of the fault zone is expressible as

$$
\text { RatiopHA }=\exp (A+B-C-D)
$$

wherein

$$
\begin{aligned}
& A=-1.25 \ln [R / \cos \beta+0.0872 \exp (0.678 \mathrm{M})] \\
& B=-0.0059 \mathrm{R} / \cos \beta \\
& C=-1.25 \mathrm{ln}[R+0.0872 \exp (0.678 \mathrm{M})] \\
& D=-0.0059 R
\end{aligned}
$$

For instance, given magnitude 7.3 and a site $6 \mathrm{~km}$ west of the fault assumed to have a dip angle $\beta$ of $60^{\circ}$, this ratio is 0.68 .

To express the underestimate in intensities derived from using distances to the surface trace, the difference in intensity estimates is a convenient mode of expression. Based on equations (5), (6), and (7), this difference may be expressed as

$$
\text { Diff }_{I}=\frac{F+G-F^{\prime}-G^{\prime}}{0.366 \ln 10}
$$

wherein 


$$
\begin{aligned}
& F=-1.24 \ln [R+0.00907 \exp (0.951 M)] \\
& G=-0.0059 R \\
& F^{\prime}=-1.24 \ln [R / \cos \beta+0.00907 \exp (0.951 M)] \\
& G^{\prime}=-0.0059 \mathrm{R} / \cos \beta
\end{aligned}
$$

Using the same example presented for PHA (a dip angle of $60^{\circ}$, a magnitude of 7.3, and a distance to the dipping plane of $6 \mathrm{~km}$ ), there is an underestimate of 0.53 intensity increments if distance to the surficial fault trace is used. These findings, along with the definition of distance required to use $K$. Campbell's equations, confirm that significant errors may arise if one estimates distances relative to the surface fault trace only. In spite of these deficiencies in ignoring dip angles, our studies also indicate that Salt Lake county results are most affected by use of more complex fault models. In Weber, Davis, and Utah counties, less space is available between the Wasatch Range and the Great Salt Lake or Utah Lake for suitable deve1opment of exposures. As a consequence, in these counties, most exposures are extremely close to the surface trace of the Wasatch fault.

The general approach of simulating many earthquake scenarios within a probabilistic framework also has advantages in estimating liquefaction probabilities. To estimate these, we first used raw data provided by Utah State University and Dames and Moore. These data include critical blow counts, water table depths, and critical accelerations for various sites examined (see [28]). Critical accelerations are those peak horizontal accelerations which may lead to liquefaction relative to a 7.5 magnitude earthquake. Note that this definition does not suggest that liquefaction will occur if the critical acceleration is equaled or exceeded in a 7.5 magnitude event. To adjust critical accelerations for earthquakes of other magnitudes, the following magnitude scaling factors have been proposed to account for cyclic effects [29]: 
Magnitude

Magnitude Scaling
Factor (MSF)

$\begin{array}{ll}7.5 & 1.0 \\ 6.75 & 1.13 \\ 6.0 & 1.32 \\ 5.25 & 1.5\end{array}$

Hence, if for a 7.5 magnitude event the critical acceleration is $0.10 \mathrm{~g}$ for a given site, the above magnitude scaling factors suggest that $0.113 \mathrm{~g}, 0.132 \mathrm{~g}$, and $0.15 \mathrm{~g}$ PHA's must occur in earthquakes having magnitudes $6.75,6.0$, and 5.25 , respectively, for liquefaction possibly to occur. Our general approach assists in incorporating such multipliers for earthquakes having magnitudes other than 7.5. Moreover, using these magnitude scaling factors and equation (2), and assuming that $K_{1}=0, K_{2}=0$, and $K_{3}=0$, a site with a critical acceleration of $0.10 \mathrm{~g}$ for a 7.5 earthquake (an adjusted critical acceleration of $0.15 \mathrm{~g}$ for a 5.25 earthquake) can have this acceleration excepted as far as $8 \mathrm{~km}$ from a 5.25 magnitude event. Although these magnitude scaling factors may be too low, this finding partially confirms our later conclusion that liquefaction-included ground failure may be a major problem even in smaller magnitude earthquakes.

It has been objected that these standard magnitude scaling factors are too low. As a consequence, we have examined the sensitivity of our pipe break estimates to alternative magnitude scaling factors. To develop these alternative factors, we have used the following equation from [30] relating severity of liquefaction to magnitude for western U.S. earthquakes:

$\log ($ LSI $)=-3.49-1.86 \log R^{\prime}+0.98 M_{W}$ 
wherein

$\begin{array}{ll}\text { LSI } & =\text { severity of liquefaction (inches) } \\ R^{\prime} & =\text { distance to the energy source }(\mathrm{km}) \\ \text { and } & =\text { moment magnitude. }\end{array}$

For estimating the onset of liquefaction, we have used two alternative assumptions: LSI $=1$ inch and LSI $=4$ inches. To develop magnitude scaling factors, it is only necessary to use a suitable attenuation relation relating PHA to magnitude and distance. Equation (2) is oniy partially suitable. If one allows $M \simeq M_{w}$ and $R \simeq R^{\prime}$, equation (2) may be used. (The values ascribed to $K_{2}{ }^{\prime}$ make no difference to the critical acceleration multipliers derived.) However, more directly suitable equations from [31] are

$$
\log P H A=0.49+0.23\left(M_{w}-6\right)-\log D^{\prime}-0.0027 D^{\prime}
$$
and

$$
D^{\prime}=\left(\left(R^{\prime}\right)^{2}+64\right)^{1 / 2}
$$

From these alternative equations for PHA and alternative assumptions for LSI at the boundary threshold, we have developed four sets of magnitude scaling factors in Table 2. Values derived are much higher than those standardly used. We have examined, for instance, consequences of using the multipliers 1.3 for 6.75 magnitude events, 2.55 for 6.0 magnitude events, and 4.1 for 5.25 magnitude events (half the values derived from using LSI = 1" and equations (11) and (12)). These greatly reduce expected liquefaction-induced ground fallures and consequently expected pipe breaks associated with these failures for smaller magnitude $(<6.4)$ scenarios. Accordingly, further research is 
Table 2

Alternative Magnitude Scaling Factors

Derived from Equations in [30], [31], and [11]

\begin{tabular}{|c|c|c|c|c|c|c|c|c|}
\hline \multirow{3}{*}{$\underset{\left(M_{W}\right)}{\text { Magni tude }}$} & \multicolumn{4}{|c|}{$\begin{array}{l}\text { Calculated Critical } \\
\text { Acceleration (\%g) } \\
\text { At Specified Magnitude }\end{array}$} & \multicolumn{4}{|c|}{$\begin{array}{l}\text { Derived Critical } \\
\text { Acceleration Multipliers } \\
\text { Relative to } 7.5 \mathrm{M} \text { Event }\end{array}$} \\
\hline & \multirow{2}{*}{\multicolumn{2}{|c|}{$\begin{array}{l}\text { Equations } \\
(11) \text { and }(12) \\
\text { LSI }=1 " \quad \text { LSI }=2 "\end{array}$}} & \multicolumn{2}{|c|}{ Equation (2) } & \multirow{2}{*}{\multicolumn{2}{|c|}{$\begin{array}{l}\text { Equations } \\
(11) \text { and }(12) \\
\text { LSI }=11 " \quad \text { LSI }=4 "\end{array}$}} & \multicolumn{2}{|c|}{ Equation (2) } \\
\hline & & & $L S I=1 "$ & LSI = 4" & & & LSI = 1" & LSI = 4 " \\
\hline 7.5 & 0.027 & 0.084 & 0.0237 & 0.075 & 1.0 & 1.0 & 1.0 & 1.0 \\
\hline 6.75 & 0.07 & 0.164 & 0.056 & 0.135 & 2.6 & 2.0 & 2.4 & 1.8 \\
\hline 6.0 & 0.13 & $0.236^{\star}$ & 0.099 & 0.21 & 4.8 & $2.8 *$ & 4.2 & 2.7 \\
\hline 5.25 & 0.174 & $0.210 *$ & 0.16 & 0.29 & 6.4 & $2.5^{\star}$ & 6.5 & 3.8 \\
\hline
\end{tabular}

* These values demonstrate that combining equations (11) and (12) yields paradoxes (these were recognized by L. Youd in his review of study findings). 
required to determine the merits of the objection that standard magnitude scaling factors [29] are too low.

Since the exceedance of adjusted critical accelerations by calculated PHA's only implies that liquefaction may occur, actual estimates of liquefaction probabilities also remain a problematic area. In the first project, we distinguished among microzones having high, medium and low susceptibilities:

Liquefaction Susceptibility of Microzone

High

Medium

Low

\section{Characterization}

the average site had critical blow counts below 12 and water table depths below $3 \mathrm{~m}$ the average site had critical blow counts below 25 and water table depths below $6 \mathrm{~m}$.

all other average sites

Figure 8 indicates the highly susceptible zones (generally near the Great Salt Lake or Jordan River) in Salt Lake and Davis counties.

In the first project, we assumed that no liquefaction-induced ground failure occurs in microzones having high liquefaction susceptibilities or in microzones whose calculated PHA's were below adjusted critical accelerations. Otherwise, we assumed that highly susceptible microzones had probabilities of liquefaction-induced ground failure of fifty percent and that this probability was ten percent for medium susceptible microzones. 


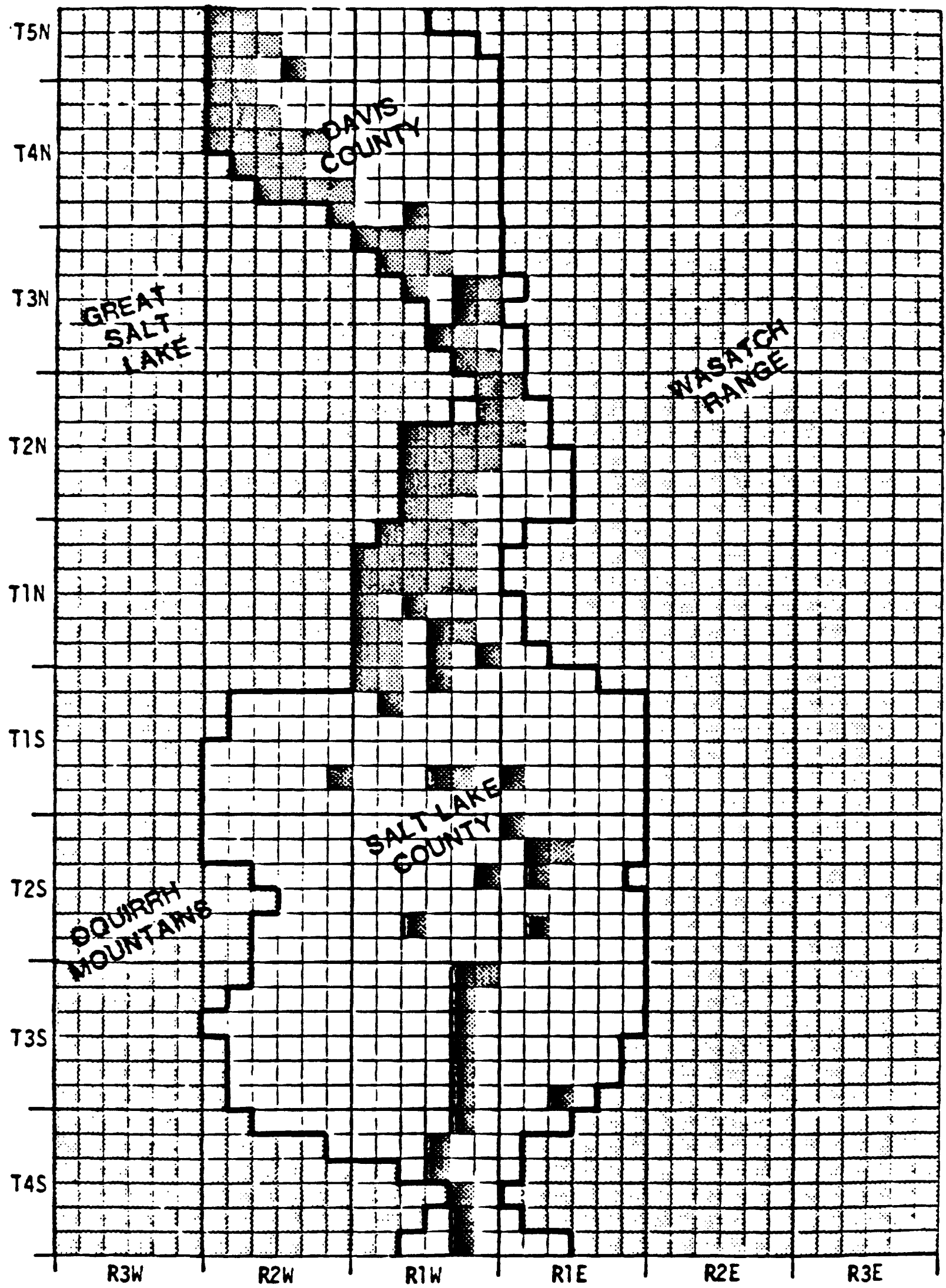

Figure 8. Microzones Assigned the Highest* Liquefaction Susceptibility (Based on Data Furnished by Utah State University and Dames \& Moore)

* = Average Critical Accelerations $\leq 0.13 \mathrm{~g} /$. Average Biow Counts $\leq 12$, and Average Water Table Depth $\leq 3 \mathrm{~m}$

$\square=$ Average Critical Accelerations > $0.13 \mathrm{~g}$, or Average Blow Counts $>12$, or Average Water Table Depth $>3 m$. 
These makeshift procedures have been replaced with others in the second project in which we have used the following general function for estimating the probability of liquefaction:

Liquefaction probability $=f\left(\operatorname{CSR}_{\text {est }} 0.011 \mathrm{~N}_{1}\right.$, MSF, $\left.\Delta\right)$

wherein

$$
\begin{aligned}
\text { CSRest }^{=} & \text {the calculated cyclic shear ratio for a given microzone } \\
N_{1}= & \text { the critical blow count (average for sites in the } \\
& \text { microzone) } \\
M S F \quad= & \text { the magnitude scaling factor (based on earthquake magni- } \\
& \text { tude) } \\
\Delta \quad= & \text { a function dependent on how much CSRest exceeds } N_{1}
\end{aligned}
$$

In the standard 7.5 magnitude earthquake, we have assumed that no liquefaction occurs if $N_{1} \geq 25$ or PHAC $a_{c} \star M S F$ or if CSRest $<0.011 N_{1}$, where $a_{c}$ is the critical acceleration and MSF is the adjustment for the earthquake magnitude. Otherwise we have assumed that the probability of liquefaction is a function of $\Delta$, the amount by which CSRest exceeds $0.011 \mathrm{~N}_{1}$. Based on the 1 imited data from [30], we have drawn a working analogy between the degree of liquefaction severity (in inches) that may occur and the probability of liquefaction-induced ground failure. We have assumed that if $\Delta$ is 0.03 , the probability is 15 percent, if $\Delta$ is 0.09 , the probability is 60 percent and if $\Delta$ is 0.22 , the probability is 99 percent. For other magnitude level earthquakes simulated, we have used the same procedure except that CSR $_{\text {est }} /$ MSF is used in place of CSRest.

Previous National Science Foundation (N.S.F.) studies and earthquake insurance studies have been adapted to develop procedures for making 
loss estimates for state-owned buildings (summaries of data and methods are found in [32] and [33]; [34] also provides useful data summaries; no published comprehensive raw loss data are available for U.S. structures, as contrasted to routine practices in the Balkan region of systematic loss data collection as shown in [35]). The loss estimation tools used employ both probabilistic methods (e.g., Monte Carlo simulations, Beta distributions to estimate probability of degree of damage relative to a sample mean) as opposed to deterministic ones. They have been adapted from methods approved by the State of California in fulfillment of the annual requirement of earthquake insurance carriers to report expected maximum credible losses and other insurance estimates for their California portfolio. Principally developed and refined for proprietary insurance studies (and from proprietary computer codes), the probabilistic methods have been derived from the deterministic ones by modeling the sources of uncertainty (e.g., distance to the fault plane, intensity, site dynamic amplification, seismic building quality, exposed population) in loss estimation probabilistically. Properly speaking, the methods employed are probabilistic, not deterministic. Even though one fixed rupture zone and magnitude are assumed, the method used implies that many loss outputs are conceivable from these assumptions. These loss outputs are calculated through Monte Carlo simulations to yield such statistics as means and variances.

The general procedures are outlined in Figure 9. Inventory data were provided by the Utah State Risk Administrator and the Utah State Division of Facilities Construction and Management. These data include facility name, address, building frame system, number of stories, construction date(s), total square footage, and replacement value of buildings and contents. To these data, we have added occupancy usage, township section, and building and contents vulnerability 


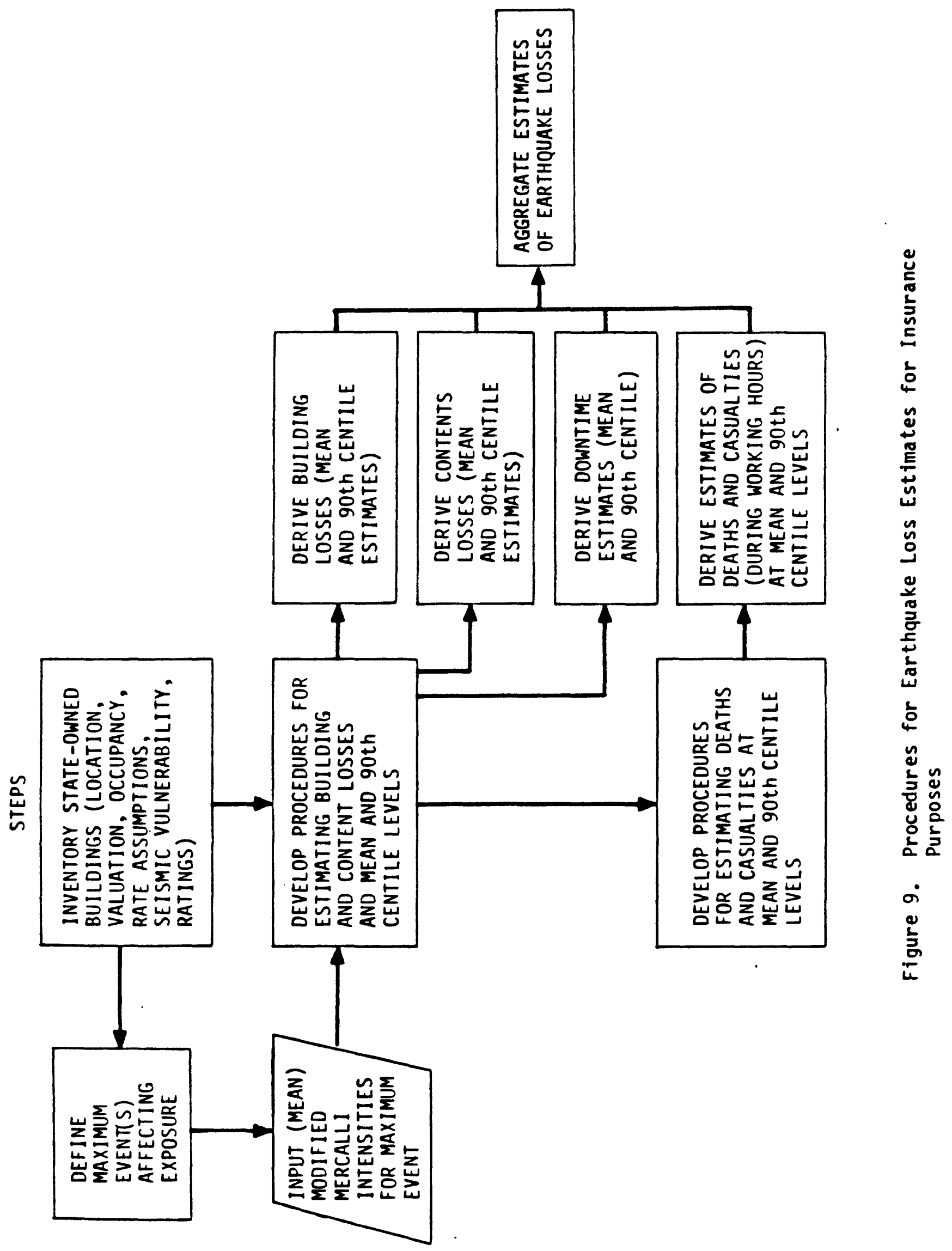


categories. Building vulnerability categories used involve four major categories, defined at the minimum level with reference to the Uniform Building Code (UBC) earthquake zone for which a structure is designed. Contents vulnerability categories are similar to those found in [34]. Procedures to estimate deaths and injuries are based on severity of expected building damage, where this severity is treated probabilistically in terms of aforementioned Beta distributions applied to deterministic loss estimates. The chief bases for estimating casualties relative to severity of building damage are derived from methods explicated in [36] and [37] and critiqued in [35].

Given what at first appears to be a limited seismic resistance of many state-owned buildings as indicated by the seismic codes governing them, the concentration of these buildings in Salt Lake County (see Figure 10), and the high shaking intensities expected in a 7.0- 7.5 $\mathrm{M}_{\mathrm{s}}$ earthquake on the Salt Lake segment of the Wasatch fault, we originally expected property and casualty losses to be significant -likely larger than those losses estimated from previous studies.

Our only surprise in this regard arose in the course of the first project when we decided to distinguish between economic building vulnerability ratings and ratings for life-safety estimates. We discovered that many state-owned buildings contain features such as numerous interior partitions and good physical condition that make them more seismically safe than would be indicated based on such economic damageability factors as age (indicative of building code used) and frame system alone. As a result, we recomend further study to formalize life-safety factors for Utah buildings so that future casualty estimates may be based on explicit procedures like those developed for 




Figure 10. Number of State-Owned Buildings with Assumed (AboveThreshold $\star$ ) Occupancies by Microzone

* Pumphouses, roadsheds etc. were excluded, as were buildings for which square footage data were unavailable. 
California structures (see [20] for life-safety visual inspection and renting procedures originaliy developed to estimate potential casualties as a means to assess risks and retrofit needs in the city of Long Beach).

We adapted previous N.S.F. lifeline research ([38], [39]) to define procedures for making earthquake risk estimates to culinary water and natural gas systems. These procedures are outlined in Figure 11. Inventoried in these projects have been the natural gas system for each of the four main counties and the following culinary water systems: Clinton (Davis County), Granger-Hunter Improvement District (Salt Lake County), Weber Basin Conservancy District (Weber and Davis counties), Salt Lake County Conservancy District, South Ogden City (Weber County), Ogden City, Provo City (Utah County), and Orem City (Utah County). The Salt Lake Department of Public Utilities was not inventoried because it has been the subject of several past seismic risk studies ([2], [4], [6], [7], and [40]). Included in these inventories are types of component, location(s) distributed by township section(s), pipe material, pipe joint, pipe length and diameter, and percent of pipe in the wasatch fault zone of deformation. To characterize this latter input we have used the broad conservative definition of the fault zone of deformation found in [2]: $457 \mathrm{~m}$ on the downthrown side and $61 \mathrm{~m}$ on the upthrown side of the fault trace. Further details of the inventory process for the natural gas system are developed in [41]. In the second project, $R$. Campbell and $M$. Salmon have made engineering site inspections of various wells, booster stations, and filtration plants in the four counties in order to develop earthquake fragility models (failure probabilities as a function of PHA) and seismic risk reduction recommendations. 


\section{STEPS}

MICROZONE AND

EVENT INPUTS

(FROM HAZARD

ESTIMATION

PROCEDURES)
INVENTORY NATURAL GAS

AND CULINARY WATER

SYSTEMS (COMPONENT

LOCATIONS, VULNERABIL-

ITIES, FUNCTIONS, LENGTHS, RELATIONS TO SURFACE

FAULT TRACES)
OUTPUTS FOR

EACH EVENT,

COMPONENT,

\& MICROZONE

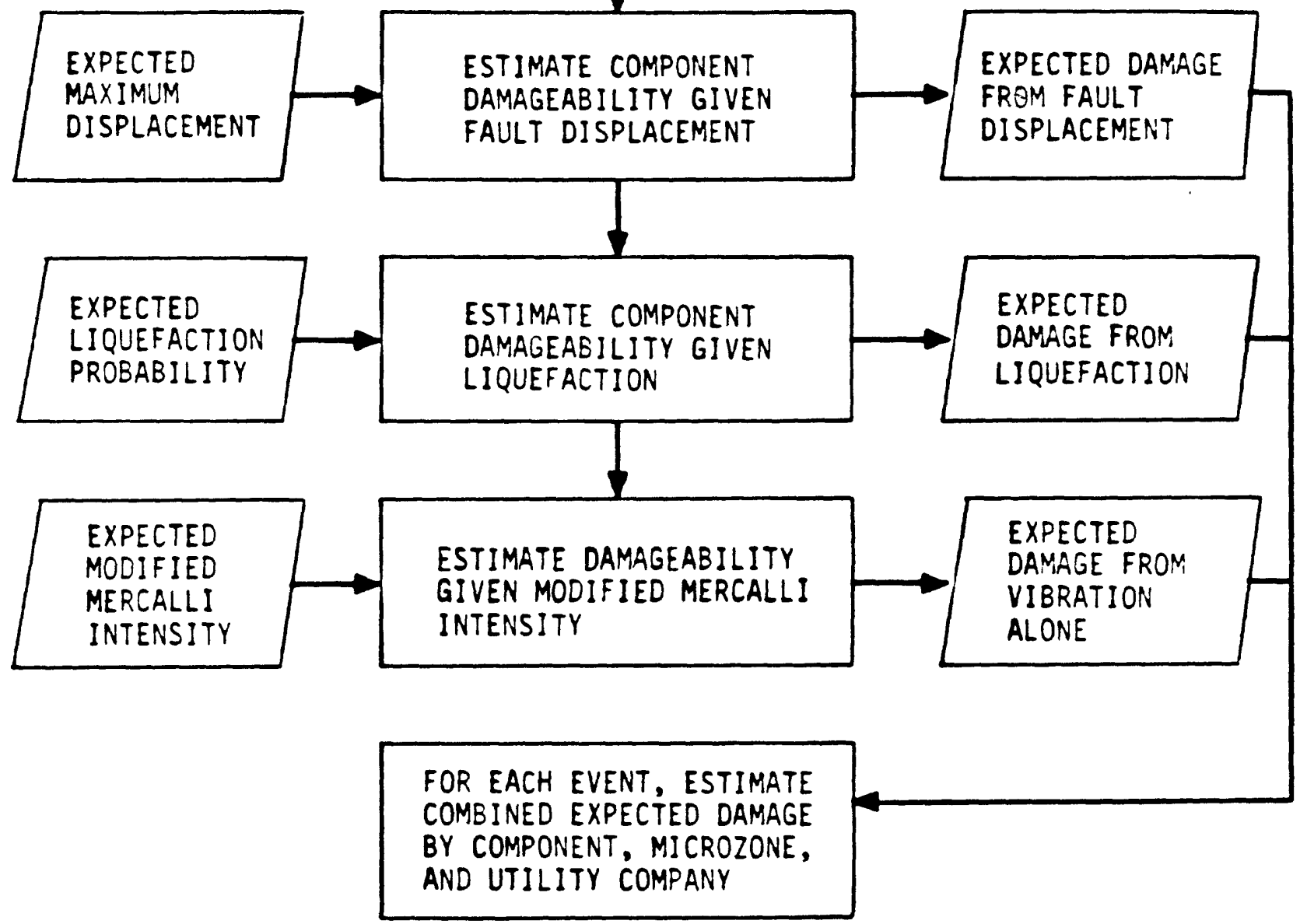

Figure 11. Damage Estimation Procedures Used for Natural Gas and Culinary Water Systems 
Figure 11 distinguishes among three hazard modes: strong ground motion, vibration-induced ground failure, and fault rupture. In the first project, we found that pipeline vulnerability models developed in [37] yielded estimates of breakage that were excessive at higher shaking intensities (Modified Mercalli intensities of IX and above). As a consequence, through the assistance of the project consultant $R$. Eguchi, we have revised those pipe vulnerability models to reflect first project findings. Revised models will be shown in the final report for the second project. Empirical data on which pipe vulnerability models are based make us believe that results developed at lesser intensities and for the hazard failure modes examined are meaningful. For instance, in the recent 1987 Whittier Narrows earthquake, the city of Whittier had cast iron breakage rates of 0.05 per $\mathrm{km}$, or about as we would predict assuming a shaking intensity of VIII (see [42]). Data summaries forming the basis for pipe vulnerability models and especially on the 1971 San Fernando Valley and the 1983 Coalinga earthquakes are found in [38], [39], [27], [41], and [42].

GENERAL RESULTS

The probabilistic approach used in this study has provided new materials to address unresolved issues on the validity of Wasatch fault loss estimates. In general, results are as expected -- with hazard estimates being higher than previous estimates, and with worstcase earthquakes yielding very high damage estimates. Some specific results, however, were surprising.

Risk estimates are improved by employing a near-source approach -- one that uses at least dip angles for the Wasatch fault and attenuation functions specially designed to account for near-field effects -principally because the wasatch fault is held to be the major source 
of larger $\left(M_{s}>6.4\right)$ earthquakes and because so many wasatch fault exposures are close to the Wasatch fault, especialiy when defined in two or more dimensions (see Figure 5 and its discussion for technical confimation). Recent and on-going liquefaction susceptibility and dynamic amplification findings, combined with this fault modeling, show that risks are significantly greater than estimates obtained from simpler models.

Indeed, vibrational hazards are severe enough in the largest earthquakes postulated $\left(M_{s}>6.4\right)$ that modeling ground failure hazards initially made little difference to damage estimates in the near-field --except with respect to the most seismically resistant facilities exposed to ground failure hazards. As a result of high pipe breakage rates developed in the first project for these larger magnitude events, we were forced to revise (downwards) breakage estimates for piping subjected to strong ground motion so that these estimates did not exceed those for piping subjected to ground failures. Extrapolation from lower intensity data has long been a problem in pipe breakage algorithms, and ground failure estimates serve as a useful upper boundary on those expected from strong ground motion.

At the high levels of ground motion expected in these larger earthquake scenarios, a large degree of uncertainty also applies to building loss and casualty estimates derived for the least seismically resistant classes of building (see [32] for a discussion of different estimates among investigators for the worst classes of buildings, and for preliminary loss estimates and loss distributions for unreinforced masonry construction in the 1983 Coalinga, California earthquakes). In other words, such high levels of strong motion test the vulnerability and damageability models principally developed from Modified Mercalli Intensity VIII data. 
Liquefaction hazards, moreover, appear to be significant enough to yield potential ground failure hazards and consequent pipeline breaks even in some near-field events of $M_{L}$ 5.5. For instance, modeling earthquake events of comparatively low magnitudes $(5.5-6.4)$ beneath selected portions of Salt Lake or Davis County initially suggest that these localized hypothetical earthquakes could yield significant ground failure problems and resulting pipe breaks in such local systems as the Granger-Hunter Improvement District or the Clinton Water Department. However, these results raise questions about research tools used. Our analysis of the sensitivity of pipe repair rates to magnitude scaling factors (MSF's) shows that non-standard multipliers (derived from Table 2) reduce expected repair estimates considerabiy. Even if research is appropriately directed to this topic, another remains--the development of liquefaction probabilities for those sites and/or microzones affected by earthquakes so that adjusted critical accelerations are exceeded by PHA's.

Assignment of probabilities in these cases also greatly affects study results--in large as well as small magnitude earthquakes simulated.

The risk estimates produced in this study have been presented to potential users -- the State of Utah Risk Administrator and representatives of local utilities inventoried and analyzed. Currently the most significant use has been to assist in the natural gas system seismic mitigation program. Key elements in this use involve participation by gas utility representatives in providing facility data, checking vulnerability and other models, and in using detailed damage estimates from several postulated earthquakes to make system flow analyses and hence to identify weak system links. Thus, full scale seismic system risks analyses have been developed, with estimation of consequences for various categories of customers (industrial, commer- 
cial, and residential) and of reduced losses through alternative mitigations. These risk analyses, moreover, have been the basis for mitigation planning and actions.

\section{State Owned Buildings Subjected to a Maximum Credible Event}

As a result of high intensities estimated in maximum credible events ( $\approx 7.3 \mathrm{Ms}$ ) generated from the Salt Lake segment of the Wasatch fault zone, state-owned buildings in Salt Lake County are expect to suffer very high property (building and content) losses, with additional losses resulting from potentially long downtimes. Table 3 sumarizes replacement values at risk by microzone (township sections) and seismic building qualities (at the minimum level, without inspection and rating, 1 refers to buildings designed to UBC seismic zone 0-1 standards, 2 to those designed to UBC seismic zone 2 standards, and 3 to those designed to UBC seismic zone 3 standards). Table 4 summarizes mean estimates of building losses, contents losses, and downtime by microzone. For all building surveyed, mean loss estimates are 39 percent of the replacement value ( $\$ 480$ million) of buildings surveyed, with downtime estimate of two-thirds of a year for many buildings.

Population exposure estimates in state-owned buildings vary considerably--depending primarily on university and governmental schedules. Nonetheless, the severe building damage estimated resulted in high estimates of deaths, severe injuries, and moderate injuries when expressed as ratios of the population exposed. Those ratios were three percent dead, four percent severely injured, and ten percent moderately injured. For the least seismically resistant class of buildings surveyed, these property and casualty loss estimates were much higher. (For details, see project report [33]; the upper limit of mean deaths estimated was twenty percent of occupants). 


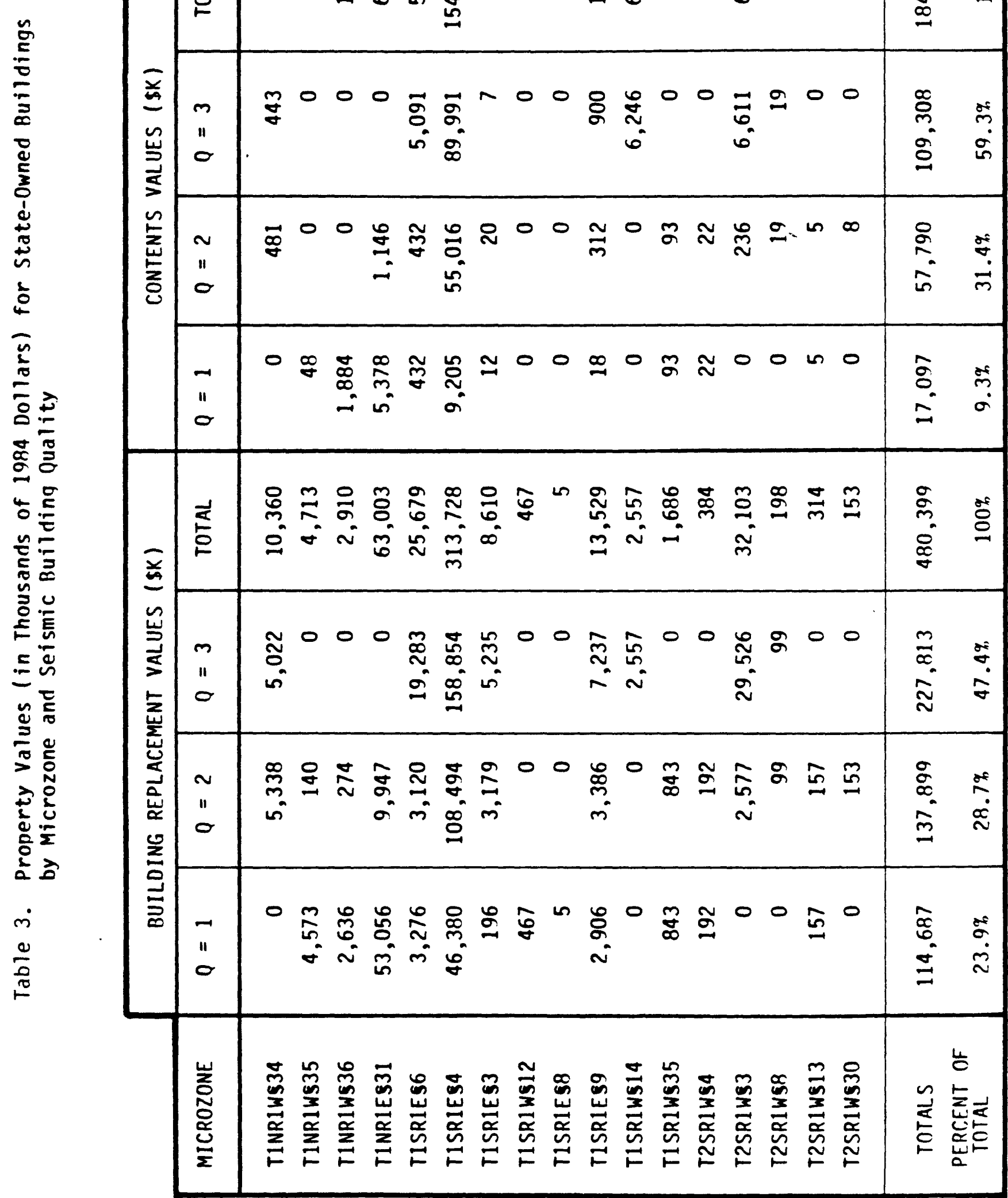


\&

$\stackrel{ \pm}{ \pm}$

葛

E

岀至

造

E山

$+$

此需

铈

순

넌

이

U

ñ⿱一⿻上丨亅八

n 잉

어동

n 응

t $x^{2}$

요 $=$

달

品

- E.

i E \&

ñ

$0 \approx 9$

$0 \geqslant \frac{1}{0}$



응

氞的

我

-

당

항

$\frac{8}{2}$

\begin{tabular}{|c|c|c|c|c|}
\hline \multirow{3}{*}{ 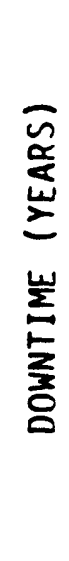 } & $\begin{array}{l}m \\
11 \\
0\end{array}$ & \%. 0 o 0 : & & \\
\hline & $\begin{array}{l}\sim \\
" 1 \\
0\end{array}$ & ఈ & & \\
\hline & $\overrightarrow{0}$ & 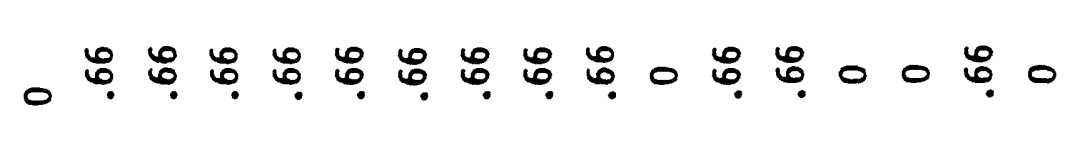 & & \\
\hline \multirow{3}{*}{ 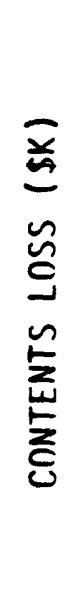 } & $\begin{array}{l}m \\
1 " \\
0\end{array}$ &  & $\begin{array}{l}\vec{\infty} \\
\stackrel{a}{a}\end{array}$ & \multirow{3}{*}{$\begin{array}{l}\overrightarrow{\tilde{o}} \\
\stackrel{i}{\cong} \\
\dot{n}\end{array}$} \\
\hline & $\begin{array}{l}\sim \\
0 \\
0\end{array}$ &  & $\begin{array}{l}\stackrel{m}{*} \\
\tilde{N}\end{array}$ & \\
\hline & $\overrightarrow{11}$ &  & $\begin{array}{l}\hat{\sigma} \\
\hat{y}\end{array}$ & \\
\hline \multirow{3}{*}{ 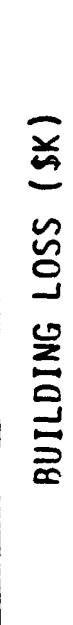 } & $\begin{array}{l}m \\
11 \\
0\end{array}$ & 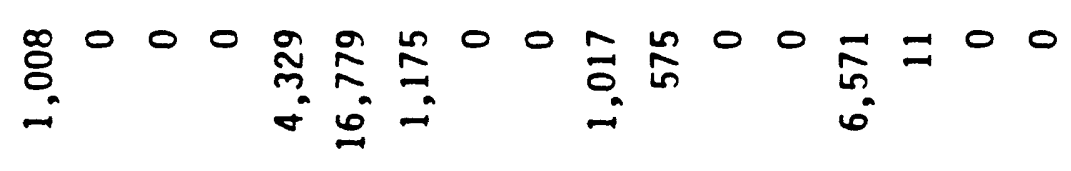 & $\begin{array}{l}n \\
\mathscr{\sigma} \\
\dot{m}\end{array}$ & \multirow{3}{*}{$\begin{array}{l}\dot{E} \\
\stackrel{0}{0} \\
\stackrel{\infty}{\infty}\end{array}$} \\
\hline & $\begin{array}{l}\sim \\
1 " \\
0\end{array}$ &  & $\begin{array}{l}\tilde{n} \\
\tilde{F}\end{array}$ & \\
\hline & $\overline{1}$ &  & $\begin{array}{l}\widehat{\alpha} \\
o \\
\vdots \\
\vdots\end{array}$ & \\
\hline & 岩 & 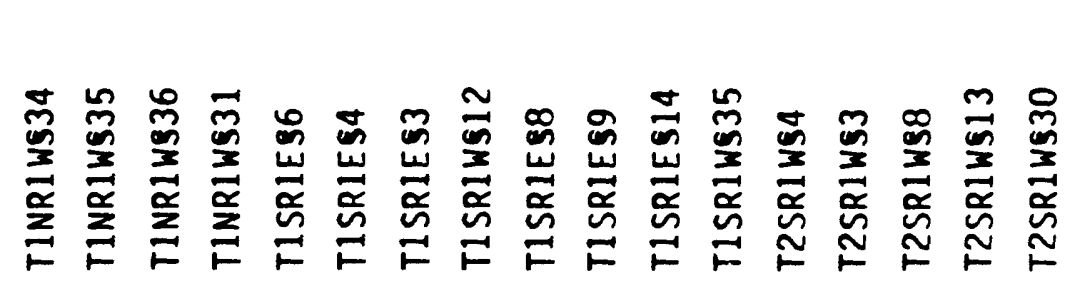 & 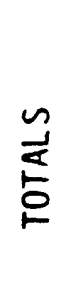 & 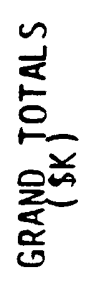 \\
\hline
\end{tabular}


As high as these estimates are, it should be noted that they reflect a refinement in characterization of the hazards posed by these buildings. Our initial estimates based on standard seismic categorization loss procedures that focus on construction features known to be seismically vulnerable, were still higher. Vulnerability categories were carefully reassessed through the adaptation of visual inspection and rating methods discussed in [21], which emphasize both economic and life-safety building hazards. Two sets of seismic ratings were subsequently developed, one for property loss estimates and the other for casualty estimates. As a result of this reassessment, aggregate property and casualty loss estimates were reduced considerably. For instance, estimated deaths dropped by a factor of 3.7 once university and technical school buildings were reassessed more carefully. Loss results for this maximum credible event are clearly very sensitive to how buildings are evaluated for seismic property and safety issues. This suggests that continued refinement of seismic inspection and rating procedures -- especially with respect to crucial safety issues -- should be encouraged for and applied to Wasatch Front buildings.

To our surprise, the dynamic amplification estimates used made less of a difference in property and casualty estimates than we had expected. When dynamic amplification factors were ignored and only basement rock intensities were used, mean building loss estimates were reduced from 39 to 28 percent and contents loss estimates were reduced from 39 to 20 percent. Estimated deaths were reduced from three to two percent, severe injuries from four to three percent, and moderate injuries from ten to eight percent of the population exposed. The magnitude ( $M_{S}$ 7.3) of the earthquake postulated and the very short distances of buildings to the Salt Lake segment of the Wasatch normal fault zone (generally within five miles) imply very high shaking 
intensities even if dynamic amplification factors are ignored. We expect these factors to have more of an influence on risk estimates for earthquakes of lesser magnitudes.

\section{Overall Earthquake Damage Expected to Water and Gas Conduits}

Based on vulnerability models developed in [38], we had originally anticipated that damage to buried conduits from earthquakes would be dominated by liquefaction-induced ground failure, with lesser contributions from fault rupture and shaking intensity. The chief reason for this hypothesis was the greater extent of exposed piping to potential liquefaction than to fault-related hazards. Figure 12 illustrates this. This figure indicates provisionary estimates of the percentage of piping exposed to fault rupture and liquefaction-induced ground failure in worst-case events for various utilities surveyed. These estimates are provisionary principally because they are based on the liquefaction probabilities (fifty percent for highly susceptible microzones and ten percent for the medium susceptible microzones) used for the first project and on the broad fault zone definition used earlier, and applied to maps in [44] and [45]. Figure 12 nonetheless illustrates how in Salt Lake and Davis counties potential liquefaction-induced ground failure covers a much greater exposure than fault rupture and appears to be a more significant hazard on an aggregate level even for worst-case earthquake events. Moreover, fault rupture is not modeled for smaller magnitude $\left(M_{S}<6.5\right)$ events, whereas liquefaction-induced failure can be extensive in smaller magnitude events. At the same time, our inventory of facilities has indicated critical ones that traverse the Wasatch fault zone of deformation.

These original hypotheses were by and large confirmed with respect to natural gas system piping. The most serious damage to this piping, 


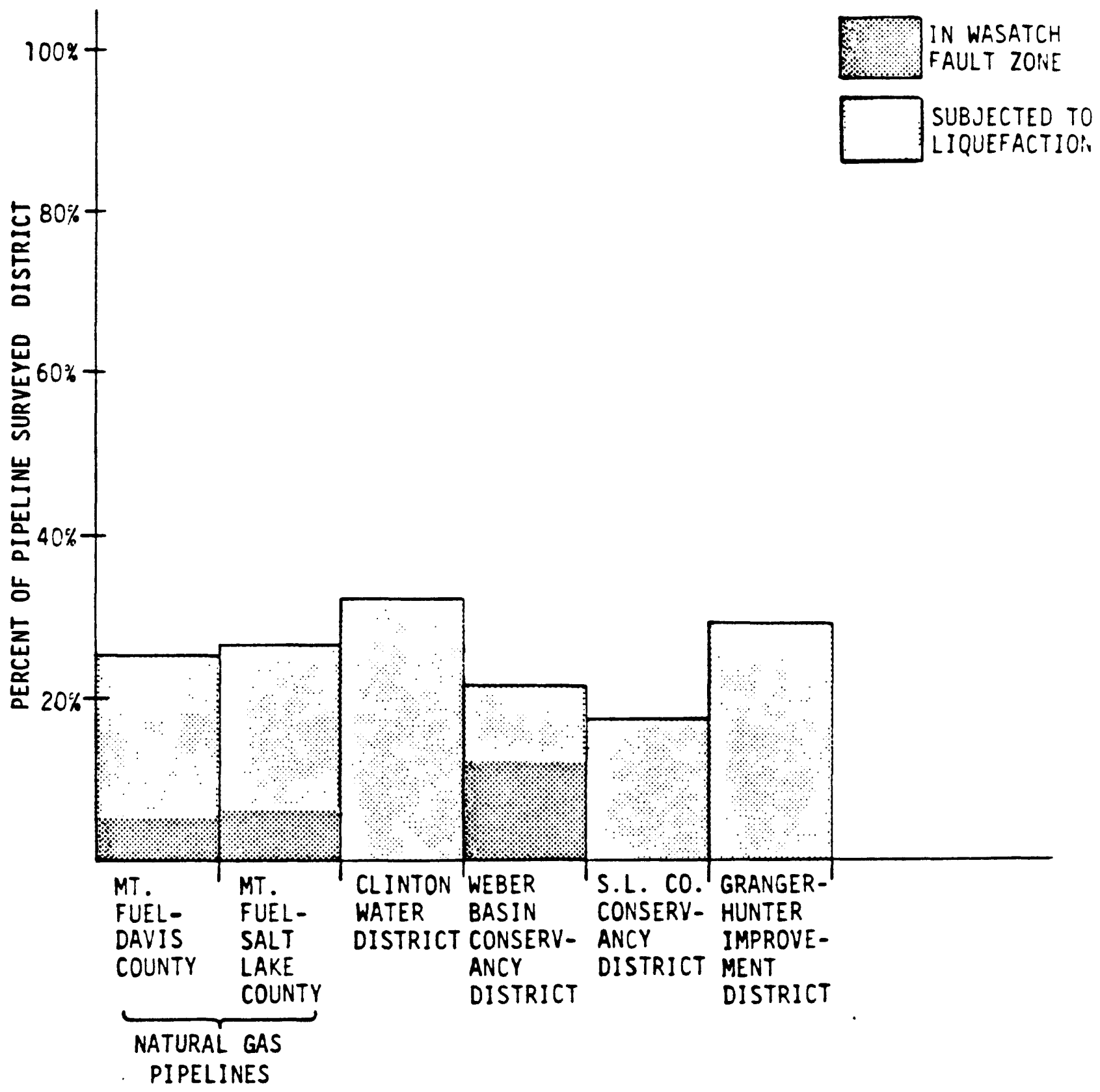

Figure 12. Percent of Pipeline Surveyed Estimated to be Subjected to Permanent Ground (Fault Rupture or Liquefaction) in Worst-Case $\left(M_{S} 7-7.5\right)$ Eartinquake Events 
especially for the highly resistant piping surveyed, naturally occurs when permanent displacement occurs when permanent displacement occurs (details of natural gas piping seismic vulnerability characteristics are discussed in [41] and [47]; shaking vulnerabilities for both butt-welded polyethylene piping and welded-steel piping are treated as $X$-grade welded steel piping in [38]). Furthermore, our inventory of Weber and Davis aqueducts in the Weber Basin Conservancy District also indicated that over one-fourth were contained in the Ogden segment of the wasatch fault zone. Rupture of key sites in this segment would therefore likely stop ample Weber Basin Conservancy District water supplies from being conveyed to local utilities until repairs are made. Several water distribution storage facilities and at least one Davis County filtration plant also appear to be located in the Wasatch fault zone of deformation (earlier evidence of water tanks in this zone were reported by B. Kaliser, and found in [6]).

We modified our original hypothesis with respect to aggregate culinary water piping in larger $\left(M_{s}>6.4\right)$ magnitude events. High shaking levels in these events contributed significantiy to expected culinary water damage. At first, we speculated that significant damage can occur to seismically vulnerable pipelines even at Modified Mercalli intensities as low as VIII and when no permanent ground displacement occurred (see [43] on the Coalinga earthquake, for which later estimates [48] suggest intensity IX or $X$ may have occurred in the city of Coalinga). Eventually we determined that pipe vulnerability models need to be modified (downwards) at these higher intensities. In the first project, it was only through an examination of an entire suite of earthquakes -- of varying magnitude and with both distant and nearfield rupture centers -- that a geographical distribution of damage dependent on liquefaction susceptibility as well as exposure became evident. 
Table 5 provides a summary of piping damage expected in larger magnitude events postulated. For each utility and for each event evaluated, we aggregated estimated piping breaks. For a given utility, these total breaks were divided by total pipeline lengths in order to construct piping break rates. We then selected the worst rates for any $M_{S} 6.7$ event simulated in order to construct Table 5. To put these rates into perspective, approximately 2800 miles (14.78 million lineal feet) of natural gas piping exists in Salt Lake and Davis counties. Hence, a break rate of 10 breaks per million lineal feet would indicate approximately 148 expected breaks to natural gas piping in those two counties.

Table 5 thus shows the widespread piping damage expected from events in which rupture occurs either on the Ogden or Salt Lake segment of the Wasatch fault zone. As a result of its comparative invulnerability to shaking damage, natural gas piping, either butt-welded polyethylene plastic or welded steel with arc-welded joints, shows much lower pipe break rates than culinary water piping. Much of the Provo City and Orem City piping systems surveyed, moreover, consisted of ductile piping with flexible joints. But even the natural gas system surveyed and evaluated would have limited immediate reliability in these larger magnitude near-field events -- except for the Utah County system which is exposed to few potential ground failures hazards.

As seen partly from the contrasts between Mt. Fuel supply break rates and culinary water system break rates, breaks from strong ground motion are expected to be numerous. However, with the revision (downwards) of pipe break estimates at higher shaking intensities, overall pipe break estimates are currentiy especially sensitive to estimates of liquefaction probability. In the 7.45 Ms earthquake from 


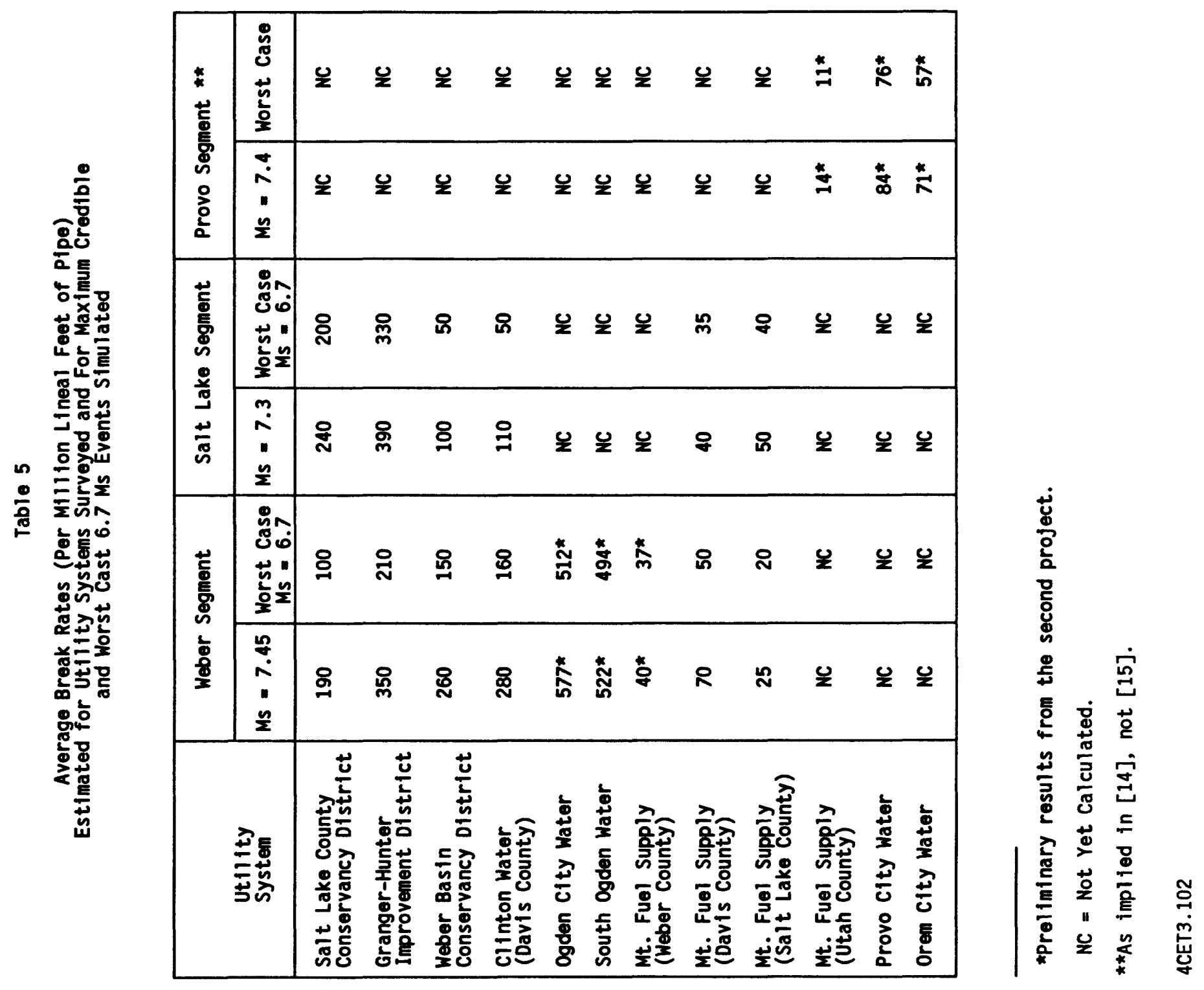


the Weber segment affecting Ogden City Water, for example, only 18 percent of all breaks estimated were from strong ground motion, with 23 percent estimated from surficial fault displacement and the remaining 59 percent from liquefaction-induced ground failures. Still, the high levels of ground shaking also suggest significant potential damage to less resistant aboveground utility structures such as unanchored water distribution storage tanks. Table 6 provides repair results in the second project broken down by the hazard that affected these results in worst case events for each system surveyed. Standard assumptions are those hazard assumptions already explored, including standard magnitude scaling factors. The relative contribution of groundshaking to estimated breaks is higher for lower magnitude events and is higher in Utah County than in Weber County.

Both projects so far suggest that liquefaction-induced ground failure is the most significant hazard mode for earthquakes possibly damaging water and gas systems in the four counties. Concentration on pipes traversing fault systems may in general ignore that breaks from fault displacements, when they occur, will be concurrent with many breaks from other hazard modes (1 iquefaction-induced ground failure, strong ground motion, and other hazard modes not studied explicitly here such as landsliding).

Table 7 examines the sensitivity of pipe repair rate estimates in maximum credible earthquakes to various geoseismic hazard assumptions used. These consist of two alternative shaking hazard assumptions (use of the extreme assumption of basement rock estimates and assumption that the rupture propagates toward all sites in the system) 
Table 6

Percent of Estimated Repairs Attributed to Different Hazard Modes in Worst Case Events (Standard Assumptions*)

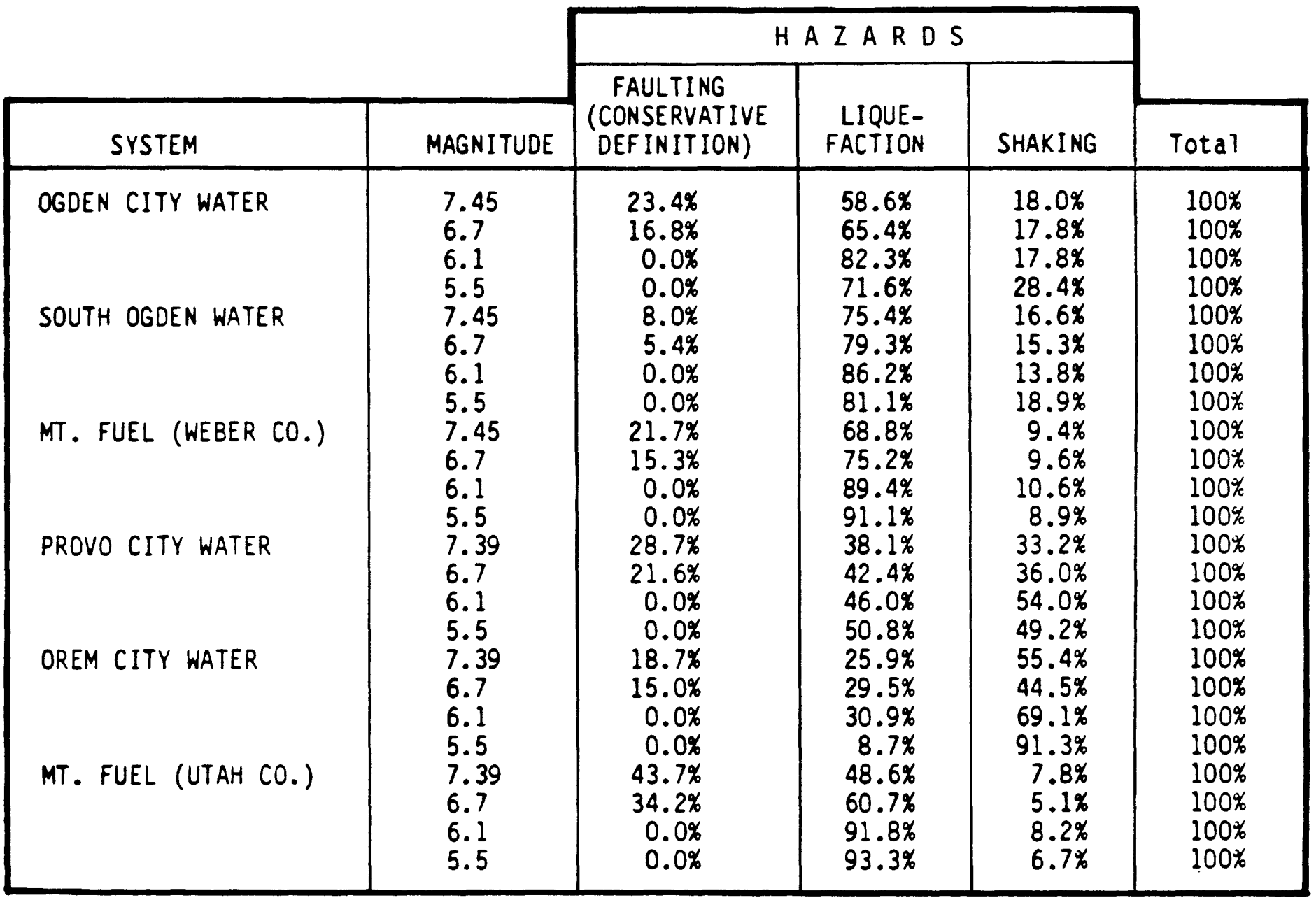

These include a $60^{\circ}$ dip angle; $k_{1}=0$ for water systems, $k_{1}=1$ for gas systems; $K_{2}=0 ; K_{3}=1 ; K_{3}^{\prime}=1$. 
Table 7

Ratio Comparisons of Pipe Repair Rates Based on Diverse Assumptions for Maximum Credible Earthquakes Affecting Water and Gas Systems in Utah and Weber Counties

\begin{tabular}{|c|c|c|c|c|c|c|}
\hline & \multicolumn{3}{|c|}{ Weber County Systems } & \multicolumn{3}{|c|}{ Utah County Systems } \\
\hline & $\begin{array}{l}\text { Ogden } \\
\text { City } \\
\text { Water }\end{array}$ & $\begin{array}{l}\text { South } \\
\text { Ogden } \\
\text { Water }\end{array}$ & $\begin{array}{l}\text { Mt. } \\
\text { Fuei } \\
\text { Supply }\end{array}$ & $\begin{array}{l}\text { Provo } \\
\text { City } \\
\text { Water }\end{array}$ & $\begin{array}{l}\text { Orem } \\
\text { City } \\
\text { Water }\end{array}$ & $\begin{array}{l}\text { Mt. } \\
\text { Fuei } \\
\text { Supply }\end{array}$ \\
\hline $\begin{array}{l}\text { Standard } \\
\text { Assumptions* }\end{array}$ & 1.0 & 1.0 & 1.0 & 1.0 & 1.0 & 1.0 \\
\hline $\begin{array}{l}\text { Standard But } \\
\text { Basement Rock PHA and PHV } \\
\text { Estimates Used }\end{array}$ & 0.94 & 0.94 & 0.95 & 0.91 & 0.80 & 0.92 \\
\hline $\begin{array}{l}\text { Standard But } \\
\text { Directivity Assumed }\end{array}$ & 1.03 & 1.02 & 1.0 & 1.08 & 1.12 & 1.01 \\
\hline $\begin{array}{l}\text { Standard But } \\
\text { Maximum Liquefaction } \\
\text { Probability }=10 \%\end{array}$ & 0.61 & 0.52 & 0.50 & 0.79 & 0.86 & 0.63 \\
\hline
\end{tabular}

* These include a $60^{\circ}$ dip angle; $k_{1}=0$ for water systems, $k_{1}=1$ for gas systems; $K_{2}=0 ; K_{3}=1 ; K^{\prime}{ }_{3}=1$. 
and one alternative assumption concerning liquefaction probability (use of ten percent as a maximum). Results for all systems are clearly sensitive to the maximum liquefaction probability assignment. Utah County water systems are especially sensitive to alternative assumptions concerning shaking hazards.

The results of this research indicate that earthquakes in Salt Lake, Davis, or Weber counties having magnitude perhaps as small as M5.5 can also yield numerous breaks to local culinary water piping, especially for those systems having much non-ductile piping. Preliminary results also suggest that smaller magnitude events $\left(M_{s}<6.5\right)$ are expected to produce over half of all expected earthquake-related breaks to culinary water piping in systems evaluated. This is largely the result of high liquefaction potential for many sites even in smaller magnitude events. Table 8 explores the sensitivity of repair rate results in smaller magnitude earthquakes to the selection of magnitude scaling factors. For systems having much non-ductile piping, even strong motions from near-field smaller magnitude events can yield considerable breaks. Clearly, though, critical acceleration multipliers used make dramatic differences in pipe repair estimates at lower magnitude levels.

Break estimates naturally vary considerably with the various earthquakes postulated in this study. Figure 13 shows how break rate estimates vary for a hypothetical Davis County system composed of welded-steel pipelines (not "X grade" as in the more resistant natural gas piping). Aggregate system damage decreases with distance of the rupture center from the system. Moreover, based on mathematical reasoning found in [49], a region of upture centers, identified by the intersection of intervals $R x$ and $R y$ as in Figure 13, contains rupture centers for which utility system reliability is minimum relative to the earthquake magnitude level examined. 
Table 8

Sensitivity of Worst-Case Repair Rates at

Lower Magnitude Levels to Assumptions on

Magnitude Scaling Factors

\begin{tabular}{|c|c|c|c|}
\hline \multirow[b]{2}{*}{ System } & \multicolumn{3}{|c|}{ Expected Repairs per Million Lineal Feet of Piping } \\
\hline & $\begin{array}{l}\text { Magnitude } \\
\text { Level }\end{array}$ & $\begin{array}{c}\text { Standard } \\
\text { Multipliers }\end{array}$ & $\begin{array}{c}\text { One Half Highest } \\
\text { Multipliers } \\
\text { In Table } 2\end{array}$ \\
\hline $\begin{array}{l}\text { Mt. Fuel Supply } \\
\text { (Weber Co.) }\end{array}$ & $\begin{array}{l}5.5 \\
6.1\end{array}$ & $\begin{array}{l}26.3 \\
30.0\end{array}$ & $\begin{array}{l}4.4 \\
6.6\end{array}$ \\
\hline $\begin{array}{l}\text { South Ogden } \\
\text { Water }\end{array}$ & $\begin{array}{l}5.5 \\
6.1\end{array}$ & $\begin{array}{l}200 \\
393\end{array}$ & $\begin{array}{l}50.1 \\
94.1\end{array}$ \\
\hline $\begin{array}{l}\text { Ogden } \\
\text { Water }\end{array}$ & $\begin{array}{l}5.5 \\
6.1\end{array}$ & $\begin{array}{l}158 \\
424\end{array}$ & $\begin{array}{r}60.6 \\
129.5\end{array}$ \\
\hline $\begin{array}{l}\text { Mt. Fuel Supply } \\
\text { (Utah Co.) }\end{array}$ & $\begin{array}{l}5.5 \\
6.1\end{array}$ & $\begin{array}{l}2.1 \\
5.4\end{array}$ & $\begin{array}{l}0.3 \\
1.0\end{array}$ \\
\hline $\begin{array}{l}\text { Provo } \\
\text { Water }\end{array}$ & $\begin{array}{l}5.5 \\
6.1\end{array}$ & $\begin{array}{l}30.3 \\
48.1\end{array}$ & $\begin{array}{l}16.4 \\
30.0\end{array}$ \\
\hline $\begin{array}{l}\text { Orem } \\
\text { Water }\end{array}$ & $\begin{array}{l}5.5 \\
6.1\end{array}$ & $\begin{array}{l}13.8 \\
34.3\end{array}$ & $\begin{array}{l}12.7 \\
24.4\end{array}$ \\
\hline
\end{tabular}




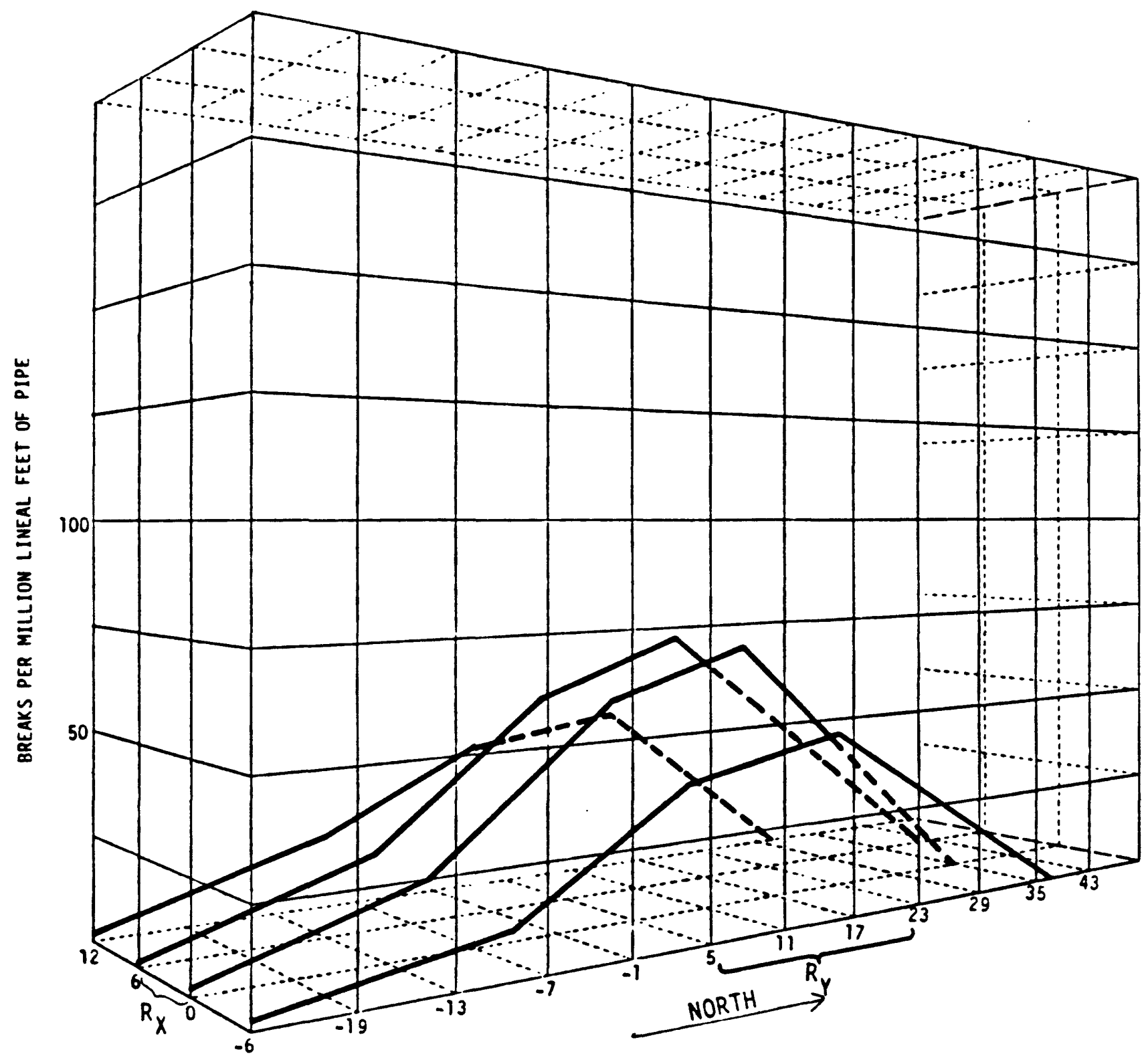

Figure 13. Break Rate Variations versus Fault Rupture Center Locations, $M_{s}=6.1$ (Davis County; Origin is Intersection of Base Line and Salt Lake Meridian)

Notation: $R$ Represents Location of Rupture Centers Causing Highest Damage to the System (for $x$ - and $y$-axes, respectively) 
For the natural gas system, which was sectionalized by county, rupture centers were determined for the magnitude levels $5.5,6.1,6.7$, and 7.0-7.5 (depending on the fault segment length and equations from [19]) so that minimum system reliability could be assessed at each such magnitude level. (The selection of rupture centers for 7.0-7.5 magnitude earthquakes was dependent only on the segment modeled -- a degenerate case of techniques used). Based on detailed damage estimates for each scenario so selected, system flow analyses were performed by the natural gas utility. These in turn were used to identify system weak links and to prioritize component retrofit and system enhancement aiternatives.

The use of smaller magnitude earthquakes proved to have several important practical advantages in this respect. First, as in the building industry (except for sites whose seismicity is dominated by a single very active fault system or for structures designed to special standards) earthquake scenarios typically used for design or redesign are smaller in magnitude than maximum credible events. The maximum credible events are less probable and may be expected to cause only a small portion of overall long-term expected earthquake losses. Second, use of smaller magnitude earthquake scenarios can provide greater assistance in identifying weak system links, e.g., those elements which, if strengthened, can improve system reliability. Even many seismically resistant facilities (not necessarily weak links and not typically priorities in a seismic risk reduction program) tend to be damaged in maximum credible earthquakes. This held in all systems surveyed except for the natural gas system in Utah County which contains highly resistant piping and which is exposed to comparatively few permanent ground failure hazards. 


\section{SUMMARY}

The combined probabilistic and near-source approach to wasatch Front risk estimates both yields new insights and raises difficulties concerning the extent of losses and risks expected. Use of many scenarios within a probabilistic framework assists in incorporating such factors as magnitude scaling factors (MSF) and in developing damage statistics that can be used as a basis for examining systemic and secondary losses. Use of many scenarios of varying magnitudes also assists in defining the types of earthquakes that are potentially dangerous and the parameters that could be further studied to improve risk estimates in these various earthquakes.

In maximum credible and other high magnitude $\left(M_{s} 6.7\right)$ localized events studied, high levels of ground shaking estimated indicated that previous pipe vulnerability models needed to be revised at intensities IX and above. These high levels -- partly as a result of findings on soil effects -- still suggest that significant culinary water piping damage and damage to above-ground utility structures (many of which have limited seismic resistance or have equipment with 1 imited lateral resistance) is expected from strong ground motion even in somewhat smaller magnitude earthquakes.

But, for natural gas and culinary water piping, estimates of expected damage are especially sensitive to liquefaction probabilities (estimated for diverse sites and/or microzones as affected by a variety of simulated earthquakes). Methods have been improvised in these projects to estimate these probabilities, but improved methods would greatly assist in refining damage estimates to buried piping. of special interest would be a review of findings in this project that even selected (near-field) earthquakes with magnitudes perhaps as low 
as 5.5 could cause extensive localized liquefaction-induced ground failures and consequent high levels of pipe breakage. This result has been demonstrated to be extremely dependent on critical acceleration multipliers used.

Results of liquefaction susceptibility studies are useful in delineating regions where overall earthquake damage to buried conduits is expected to be greater. This is particularly so with respect to smaller magnitude $\left(M_{s}<6.5\right)$, more distant earthquake scenarios, or more seismically resistant buried conduits. More detailed analysis of microzones with large exposures and high liquefaction susceptibilities would provide information valuable to Wasatch Front earthquake risk reduction problems. This analys is may involve gathering additional data on sites within these microzones, developing improved procedures for defining liquefaction potentials for areas rather than sites, associating liquefaction susceptibility data with specific facilities, or using smaller cell grids.

Losses to less seismically resistant state-owned building are estimated to be extremely high -. even higher than the 39 percent estimated for all state-owned buildings -- in worst-case events. These losses include probable long-term downtime and consequent disruption of governmental and university operations. Since life-safety hazards may also be significant, we recommend a more detailed visual inspection and rating of the most seismically vulnerable and densely occupied facilities.

The approach used here has also proved to be practical. Its use by the natural gas utility in defining seismic risk reduction plans indicates that a probabilistic approach can be successfully applied to network as well as to building problems. Participation by utility 
representatives in study phases lends both credibility and meaning to results for those who can employ them in strengthening systems.

\section{ACKNOWLEDGEMENTS}

We thank J. Keaton, Dames and Moore, L. Reaveley, Reaveley \& Reaveley Engineers, D. Ford, Ductile Iron Pipe Research Association, and S.T. Algermissen, L. Highland, and D. Perkins, United States Geological Survey for their careful reviews. We also thank the American Society of Civil Engineers for permission to reproduce Figures 2, 6, 8, 11 and 12 in this paper from an earlier publication. These projects were supported by U.S.G.S. Awards No. 14-08-001-22013 and 14-08-0001-G1394. This support is gratefully acknowledged.

\section{REFERENCES}

1. J. H. Wiggins Company, "Considerations and Alternatives for Abatement of Seismically Hazardous Existing Buildings in Utah," Redondo Beach, CA: prepared for the Seismic Safety Advisory Council, State of Utah, July 1979.

2. Algermissen, S.T., A.M. Rogers, W.W. Hays, D.M. Perkins, D.O. Van Strien, H.C. Hughes, R.C. Hughes, H.J. Lagorio, and K.V. Steinbrugge, A Study of Earthquake Losses in the Salt Lake City, Utah Area, U.S.G.S. Open-File Report 76-89.

3. Liu, S.C., "Earthquake Protection of Communications Facilities," Proceedings of the Sixth World Conference on Earthquake Engineering, Vol. III, New DeThi, India, 1977.

4. Bresko, D., D. Hendrickson, and I. Oppenheim, "Seismic Risk Analysis of an Urban Water System," Lifeline Earthquake Engineering: Proceedings of the Second Specialty Conference, New York: ASCE, 1981. 
5. Taylor, Craig E. and D.B. Ward, "Seismic Risk Assessment of Utah Primary and Secondary Schools and Recommendations for Risk Reduction," Salt Lake City: Seismic Safety Council, State of Utah, 1979.

6. Taylor, C.E. and D.B. Ward, "Seismic Risk Assessment of Utah Culinary Water Supply Systems and Recommendations for Risk Reduction," Salt Lake City: Seismic Safety Advisory Council, State of Utah, 1981.

7. Highland, Lynn M., "Earthquake Hazards to Domestic Water Distribution Systems in Salt Lake County, Utah," Assessment of Regional Hazards and Risk Along the Wasatch Front Utah, ed. by P.L. Gori and W.W. Hays, Reston, Va.: U.S., Geological Survey Open-File Report 87-585, 1987.

8. Algermissen, S.T. and K.V. Steinbrugge, "Seismic Hazard and Risk Assessment: Some Case Studies," Geneva Papers on Risk and Insurance, Vol. 9, No. 30, January 1984.

9. Utah Seismic Safety Advisory Council, "A Brief Summary of Earthquake Safety in Utah and Abbreviated Recommendations for Risk Reduction," Salt Lake City, Utah: Utah Seismic Safety Advisory Council, Report 22, 1981.

10. Utah Geological and Mineral Survey, Governor's Conference on Geologic Hazards, Salt Lake City, Utah; Utah Geological and Mineral Survey Circular 74, 1983.

11. Campbe11, Kenneth W., "Predicting Strong Ground Motion in Utah," in press to Hays, W.W. and P. L. Gori, Eds., in Assessment of Regional Hazards and Risk Along the Wasatch Front, Utah, ed. by P.L. Gori and W.W. Hays, U.S.G.S. Open-File Report 87-585, Reston, VA, 1987.

12. Keaton, Jeffrey R., Donald R. Currey, and Susan J. 01ig, Paleoseismicity and Earthquake Hazards Evaluation of the West Valley Fault Zone, Salt Lake City Urban Area, Utah. Salt Lake City, Utah: Dames \& Moore and Department of Geography, University of Utah, U.S. Geological Survey Contract No. 14-08-0001-22048, March 1987.

13. Robison, Robert M., "The Surficial Geology and Neotectonics of Hansel Valley, Box Elder County, Utah," M.S. Thesis, Utah State University, Logan, Utah, 1986. 
14. Wheeler, Russel1 L. and Katherine B. Krystinik, "Persistent and Nonpersistent Segmentation of the Wasatch Fault Zone, Utah Statistical Analysis for Evaluation of Seismic Hazard" in Assessment of Regional Hazards and Risk Along the Wasatch Front, Utah, ed. by P.L. Gori and W.W. Hays, Reston, VA U.S.G.S. Open-File Report 87-585, 1987.

15. Machette, Michael N., Stephen F. Personius, and Alan R. Nelson, "Quaternary Geology Along the Wasatch Fault Zone: Segmentation, Recent Investigations, and Preliminary Conclusions," in Assessment of Regional Hazards and Risk Along the Wasatch Front, Utah, ed. by P.L. Gori and W.W. Hays, U.S.G.S. Open-File Report 87-585, Reston, VA., 1987.

16. Hutton, L.K., "1987 Whittier Narrows Earthquake: Prior Seismicity and Comparison with the 1919 'Whittier' Sequence," California Institute of Technology, Seismological Laboratory 252.21, Nov. 1987.

17. Alfors, John T., "Regional Geology of the Coalinga, California Area," in The 1983 Coalinga, California Earthquakes, Sacramento, CA: California Department of Conservation, Division of Mines and Geology, Special Publication 66, 1983.

18. Algermissen, S.T., D.M. Perkins, P.C. Thenhaus, S.L. Hanson, and B.L. Bender, Probabilistic Estimates of Maximum Acceleration and Velocity in Rock in the Contiguous United States, U.S.G.S. Open-File Report 82-1033.

19. Arabasz, Walter J., James C. Pechmann, and Ethan D. Brown, "Observational Seismology and the Evaluation of Earthquake Hazards and Risk in the Wasatch Front Area, Utah," in Assessment of Regional Earthquake Hazards and Risk Along the Wasatch Front, Utah, ed. by P.L. Gori and W.W. Hays, Reston, VA, U.S. Geological Survey Open-File Report 87-585 1987.

20. Bonilla, M.G., R.K. Mark, and J.J. Lienkaemper, "Statistical Relations Among Earthquake Magnitude, Surface Rupture Length, and Surface Fault Displacement," Bulletin of the Siesmological Society of America, Vol. 74, No. 6, Pp. 2379-2411, December 1984.

21. Smith, Robert and William Richins, "Seismicity and Earthquake Hazards of Utah and the Wasatch Front: Pardigm and Paradox," in Proceedings of Conference XXVI, A Workshop on "Evaluation of Regional and Urban Earthquake Hazard and Risks in Utah", ed. by 
W.W. Hays and P.L. Gori, Reston, Va., U.S., Geological Survey Open-File Report 84-763, 1984.

22. Ronald Bruhn, written communication, 1985.

23. Bruhn, R.L., P.R. Gibler, W. Houghton, and W.T. Parry, "Structure of the Salt Lake Segment, Wasatch Normal Fault Zone: Implications for Rupture Propagation During Large Earthquakes," in Assessment of Regional Earthquake Hazards and Risk Along the Wasatch Front, Utah, ed. by P.L. Gori and W.W. Hays, Reston, VA, U.S. Geological Survey Open-File Report 87-585, 1987.

24. Campbell, Kenneth, "Near-Source Attenuation of Strong Ground Motion for Moderate to Large Earthquakes -- An Updated and Suggested Application to the Wasatch Fault Zone of North-Central Utah," pp. 483-499, U.S.G.S. Open-File Report 84-763.

25. Rogers, Albert, D. Carver, W. Hays, K. King, and R. Miller, "Preliminary Estimates of Geographic Variations in Relative Ground Shaking in the Wasatch Fault Urban Corridor," U.S.G.S. Open-File Report 84-763.

26. Mabey, Donald R., "Subsurface Geology Along the Wasatch Front," in Assessment of Regional Earthquake Hazards and Risk Along the Wasatch Front, Utah, ed. by P.L. Gori and W.W. Hays, Reston, Va.: U.S.G.S. Open-File Report 87-585, 1987.

27. Wiggins, J.H., C.E. Taylor, R.T. Eguchi, and J.E. Slosson, "Earthquake Hazards and Risk Mitigations: Identification and Evaluation Methods," three volumes, Redondo Beach, CA: J.H. Wiggins Co., technical report 1373-1 for the Federal Emergency Management Agency 1981.

28. Anderson, Loren R., J.R. Keaton, K. Audrey, and S.J. Ellis, "Liquefaction Potential Mapl for Davis County, Utah," Logan, UT and Salt Lake City, UT., U.S. Geological Survey Contract No. 14-08-0001-19127, February 1982.

29. Seed, H. and I.M. Idriss Ground Motions and Soil Liquefaction During Earthquakes, Berkeley, CA: Earthquake Engineering Research Institute, 1983.

30. Youd, T. Leslie, and David M. Perkins, "Mapping of Liquefaction Severity Index," Journal of Geotechnical Engineering, Vol. 113, No. 11, November, 1987. 
41. MCDonough, Peter W. and Craig E. Taylor, "Assessing Seismic Response of Utah Gas Systems," Earthquake Spectra, Vol. 2, No. 4, 1986.

42. Schiff, Anshel J., "Response of Lifelines to the Whittier Narrows Earthquake of 1987 and Their Effect on the Emergency Response," paper submitted to Earthquake Spectra, 1988.

43. Trautmann, C.H., T.D. O'Rourke, M.D. Grigoriu and M.J. Khater, "Systems Model for Water Supply Following Earthquakes," pp. 30-50, Lifeline Seismic Risk Analysis -- Case Studies, New York City: America Society of Civil Engineers, 1986.

44. Isenberg, J. and C.E. Taylor, "Performance of Water and Sewer Lifelines in the May 2, 1983 Coalinga, California Earthquake," pp.190-211, Lifeline Earthquake Engineering: Performance, Design and Construction, New York City: American Society of Civil Engineers, 1984.

45. Cluff, L.S., C. Glass, and G. Brogan, Wasatch Fault Investigation Maps, 1970, reproduced at the Utah Geological and Mineral Survey, Salt Lake City, Utah.

46. Scott, William E. and Ralph R. Shroba, "Surficial Geologic Map of an Area along the Wasatch Fault Zone in the Salt Lake Valley, Utah," U.S.G.S. Open-File Report 85-448.

47. Taylor, C.E. and P.W. MCDonough, "Earthquake Risks to Utah Water and Gas Systems," pp. 70-87, Lifeline Seismic Risk Analysis Case Studies, New York City: American Society of Civil Engineers, 1986.

48. Thiel, Charles C. and Theodore C. Zsuttys, "Earthquake Parameters and Damage Statistics," San Francisco, CA: Forell/Elsesser Engineers under U.S.G.S. Contract 14-08-0001-G1181, 1987.

49. Taylor, C.E., M.R. Legg, J.M. Haber, and J.H. Wiggins, "New Lifeline Multi-Scenario Seismic Risk Techniques with a Model Application," Civil Engineering Systems, pp. 77-83, Vo1. 2, June 1985. 
31. Joyner, W.F. and T.E. Fumal, "Predictive Mapping of Earthquake Ground Motion," in Evaluating Earthquake Hazards in the LoS Angeles Region--An Earth-Science Perspective, Washington, D.C.: U.S. Government Printing Office, U.S. Geological Survey Professional Paper 1360.

32. Wiggins, J.H. and C.E. Taylor, "Earthquake Performance of Low-Rise Construction," Vol. 2, Long Beach: NTS Engineering report 86-1442 for the National Science Foundation, 1986.

33. Taylor, Craig E., J.H. Wiggins, J.M. Haber and D.B. Ward, "A Systems Approach to Wasatch Front Seismic Risk Problems," Long Beach, CA: NTS Engineering, U.S. Geological Survey Contract No. 14-08-001-22013, February 1986.

34. Steinbrugge, Karl V., Earthquakes, Volcanos, and Tsunamis: An Anatomy of Hazards, New York City: Skandia American Group, 1982.

35. Wiggins, John H. and C.E. Taylor, editors and contributors along with J. Petrovski et al., "Earthquake Rehabilitation Manual for Buildings," Redondo Beach, CA: J.H. Wiggins Company Technical Report No. 84-1496 with Natural Science Foundations support, 1984, published as Building Construction Under Seismic Conditions, vol. 4, Vienna: United Nations Industrial Development Programe, 1985.

36. Whitman, R.V., "Seismic Design Decision Analysis," Journal of the Structural Division, Proceedings of the American Society of Civil Engineers, May 1975.

37. Anagostopoulos, S. and R. Whitman, "On Human Loss Prediction in Buildings During Earthquakes," in Proceedings of the Sixth World Conference on Earthquake Engineering, New Delhi, India, 1977.

38. Eguchi, R.T., M.R. Legg, C.E. Taylor, L.L. Philipson, and J.H. Wiggins, "Earthquake Performance of Water and Gas Supply Systems," Redondo Beach, CA: J.H. Wiggins Company Report No. 83-1396-5 for the National Science Foundation, June 1983.

39. Taylor, C.E., J.M. Haber, M.R. Legg, W.F. Heubach, and J.H. Wiggins, "Earthquake Vulnerability of Water and Natural Gas Supply Systems," Long Beach, CA: NTS Engineering Technical Report 86-1466, for the National Science Foundation, 1986.

40. Taylor, C.E. and E. Bigler, "A Preliminary Study of Possible Earthquake Problems to Salt Lake County Water Supply Systems," report to the Governor of Utah, May 1982. 